\author{
UNIVERSIDADE DE SÃO PAULO \\ FACULDADE DE FILOSOFIA, LETRAS E CIÊNCIAS HUMANAS \\ DEPARTAMENTO DE LETRAS CLÁSSICAS E VERNÁCULAS \\ PROGRAMA DE ESTUDOS COMPARADOS DE LITERATURAS \\ DE LINGUA PORTUGUESA
}

\title{
A (de)formação da imagem: Pinheiro Chagas refletido pelo monóculo de Eça de Queirós
}

\section{Jane Adriane Gandra Veloso}

Dissertação de Mestrado apresentada ao Programa de Pós Graduação em Estudos Comparados de Literaturas de Língua Portuguesa, do Departamento de Letras Clássicas e Vernáculas da Faculdade de Filosofia, Letras e Ciências Humanas da Universidade de São Paulo, para obtenção do título de Mestre em Letras.

Orientador: Prof. Dr. Paulo Motta Oliveira

v.1

São Paulo

2007 


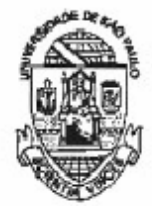

\section{UNIVERSIDADE DE SÃO PAULO}

\section{Relatório de Defesa}

Relatório de defesa pública de Dissertação do(a) Senhor(a) Jane Adriane Gandra Veloso no Programa: Letras (Estudos Comparados de Literaturas de Língua Portuguesa), do(a) Faculdade de Filosofia, Letras e Ciências Humanas da Universidade de Săo Paulo.

Aōs 13 diāś dó mẻśs de junhioo de 2007, no(a) Sala de Concursos realizou-se a Defesa da Dissertaçăo do(a) Senhor(a) Jane Adriane Gandra Veloso, apresentada para a obtenção do título de Mestre em Letras - Área: Estudos Comparados de Literaturas de Lingua Portuguesa, intitulada:

"A (de)formaçăo da imagem: Pinheiro Chagas refletido pelo monócula de Eça de Queirós"

Após declarada aberta a sessăo, $Q$ (a) Sr(a) Presidente passa a palavra aos examinadores para as devidas argüiçס̃es que se desenvolvem nos termas regimentais. Em seguida, a Comissão Julgadora proclama o resultado:

\begin{tabular}{|c|c|c|c|}
\hline Nome dos Participantes da Banca & Vinculo do Docente & Sigla da Unidade & Resultado \\
\hline Paulo Fernando da Motta de Oliveira & Presidente & FFLCH - USP & Aprovado \\
\hline Helder Garmes. & Titular & FFLCH - USP & Aprovado \\
\hline Osmar Pereira Oliva & Titular & UEMC - Externo & Aprovado \\
\hline \multicolumn{4}{|l|}{ Resultado Final: Aprovado } \\
\hline \multicolumn{4}{|c|}{ Parecer da Comissāo Julgadora * } \\
\hline
\end{tabular}

A banca examinadora da dissertaçăo de mestrado de Jane Adriane Gandra Veloso aprava com distinçaão e indicaçăo para publicação o trabalho "A (de)formação da imagem: Pinheiro Chagas refletido pelo monóculo de Eça de Queirás"

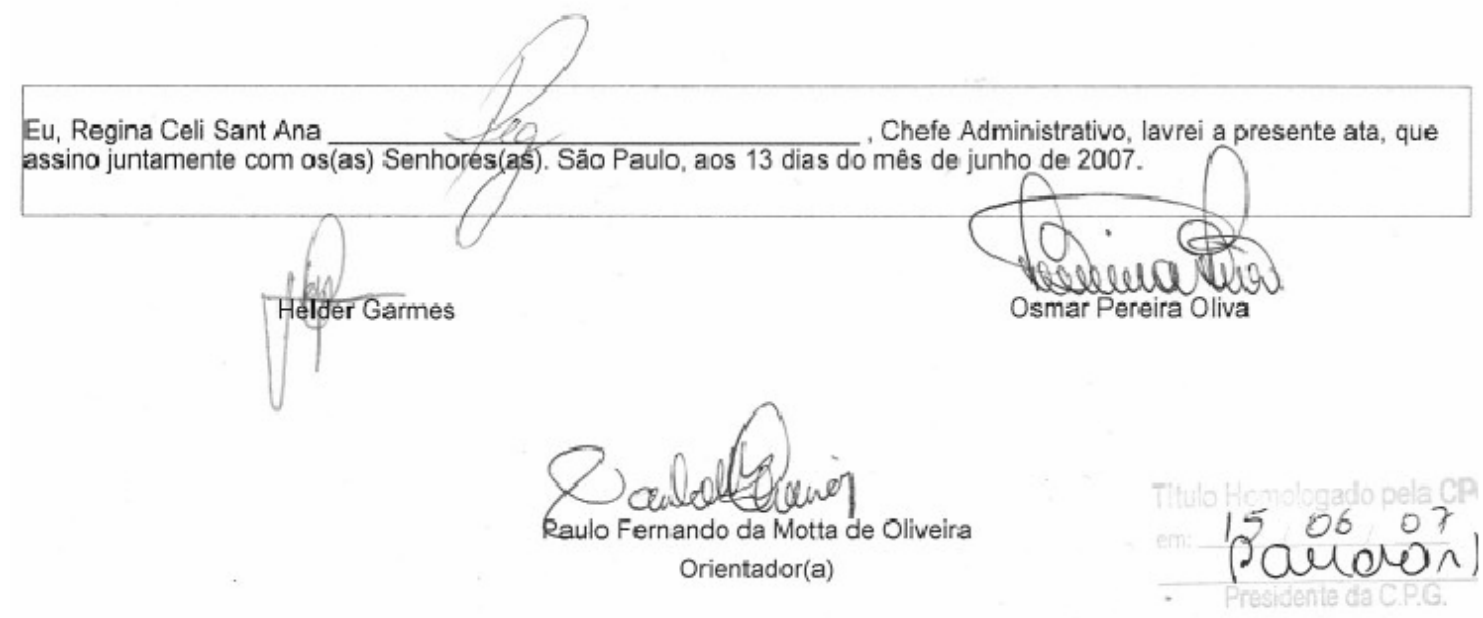

- Obs: Se o candidato for reprovado por algum dos membros, o preenchimento do parecer é obrigatório. Nos termos do artigo 110, do RG-USP, encaminhe-se o presente relatório à CPG, para homologação. 
Não há morte Quando se viveu A face da vida que se quis.

(José Craveirinha, Não há morte, 1984)

A meu querido pai, Aloísio de Araújo Gandra (In Memorian) e a minha "Tia Chiquita” (In Memorian) 
Mãe,

Sei que cada vitória nossa é sua.

E imagino que cada dor de um filho seu também seja.

Você, que conhece todas as nossas manhas, defeitos, qualidades, vontades, medos, enfim, quem verdadeiramente somos.

Que não adula as nossas fraquezas, falando-nos aquilo que queremos ouvir e o que não queremos,principalmente.

Quantas vezes, e você sabe disso, tive raiva de ouvir a verdade, porque sou temperamental, e você não cedeu à queda de braço.

Se existe um alguém que não falta em minha história, este é você. Você, que de forma singular, conseguiu tornar o difícil, maravilhoso: os natais sem muita provisão, mas cheio de festa, com rocamboles $e$ refrigerantes. Você se lembra? A gente se divertia! Um dos momentos mais prazerosos de nosso convívio, e confesso, ainda os temos, é ouvi-la contar histórias, de seu passado, dos casos de família, dos seus inventos, “dos figos da figueira que o seu pai cortou”, da infância que a gente não lembra mais.

Mãe,

por toda a sua história de vida, a gente sabe que não foi fácil, e pelas inumeráveis renúncias pelo fato de ser mãe, este mestrado não poderia ser de outra pessoa, a não ser, seu. 


\section{AGRADECIMENTOS}

À CAPES, pela concessão de bolsa de estudos que favoreceu a elaboração desta pesquisa. A todos aqueles que, de forma direta ou não, contribuíram para a execução desta pesquisa.

À Eliane Junqueira e Águida de Aguiar, pelo comprometimento e dedicação à minha pesquisa, nas incansáveis buscas por Pinheiro Chagas nos acervos de suas bibliotecas.

Aos Professores, Dr. Eduardo Martins e Dr. Hélder Garmes, pelas valiosas sugestões no exame de qualificação.

Ao Prof. Dr. Paulo Motta de Oliveira, pela confiança, paciência, disponibilidade e orientação.

Ao Prof. Dr. Osmar Oliva, grande incentivador de meus estudos que, por diversas vezes, compartilhou comigo as angústias acadêmicas, fazendo leituras, criticando e propondo idéias.

À Silvia Santos, companheira de mestrado, que compartilhou os momentos de lágrimas e de risos.

Aos primos queridos, Jaime, Janilson, Beth, Juliana, Júnior, Leila, Leonardo, Sérgio, Hebert, Adriana, Cláudia, Alysson, Aline e Caroline.

À tia Marlene, tia Marlúcia e tio Getúlio, pelo carinho de todas as horas.

À minha tia Ruth, que me apoiou incondicionalmente em todos os meus projetos de vida.

À Janine, Marcelo, Sheila e Rosângela, irmãos de coração.

Aos amores de Dinha, Mayalle, Vitor Hugo, Matheus, Henrique, Túlio e Maria Fernanda. Aos meus amados irmãos, Jeanine, Janderson e Aline.

A Deus, por tudo. 
RESUMO

VELOSO, J.A.G. A (de)formação da imagem: Pinheiro Chagas refletido pelo monóculo de Eça de Queirós. 2007. 161 f. Dissertação (Mestrado) - Faculdade de Filosofia, Letras e Ciências Humanas, Universidade de São Paulo, São Paulo, 2007.

Manuel Pinheiro Chagas (1842-1895) foi, na sua época, uma personalidade influente, participando ativamente tanto no campo das letras como no da política. Além disso, ele foi autor de uma obra multiforme e de caráter popular, lida, em seu tempo, com grande interesse e entusiasmo. Contudo, hoje, é inquestionável o apagamento literário desse escritor no cânone português, enquadrado num lugar à sombra mesmo de escritores menores. O objetivo central deste trabalho consiste em evidenciar na trajetória literária de Manuel Pinheiro Chagas os fatos que, de forma decisiva, contribuíram para o seu desaparecimento do cânone. Será visto que nestes acontecimentos ocupa um papel central Eça de Queirós, que não só conseguiu apagar a importante participação de Chagas como político, crítico, historiador e prosador, mas reduziu a figura de seu desafeto, imortalizandoa no retrato-sátira de um patriota conservador e reacionário, sob o codinome de "brigadeiro do tempo de D. Maria I".

Palavras-chave: Manuel Pinheiro Chagas - Eça de Queirós - Ostracismo Literário Polêmicas - Histórias Literárias. 
ABSTRACT

VELOSO, J.A.G. Image (dis)tortion: Pinheiro Chagas reflected by Eça de Queirós's monocle. 2007. 161 f. Paper (Master's degree) - Faculdade de Filosofia, Letras e Ciências Humanas, Universidade de São Paulo, São Paulo, 2007.

Manuel Pinheiro Chagas (1842-1895) was, in his time, an influential personality who took active part both in the field of literature and in politics. Moreover, he was the author of a multiform work with popular characteristics, read, in his time, with much interest and enthusiasm. Nevertheless, today, the literary erasure of this writer from the Portuguese canon is unquestionable, placed somewhere under the shadow of even second-rate writers. The central aim of this work is to show in Manuel Pinheiro Chagas's literary trajectory those facts which, in a decisive way, made him disappear from the canon. It will be shown that in these events Eça de Queirós plays a central role. He not only managed to erase Chagas's important participation as a politician, a critic, a historian, and a prose writer, but reduced the figure of his foe by immortalizing it in the satire-portrait of a conservative, reactionary patriot, under the code-name of "Brigadier from the time of D. Maria I".

Key words: Manuel Pinheiro Chagas - Eça de Queirós - Literary Ostracism Controversies - Literary Histories. 
VELOSO, J.A.G. La (de)formación de la imagen: Pinheiro Chagas reflejado por el monóculo de Eça de Queirós. 2007. 161 f. Tesis (Maestría) - Faculdade de Filosofia, Letras e Ciências Humanas, Universidade de São Paulo, São Paulo, 2007.

Manuel Pinheiro Chagas (1842-1895) fue, en su época, un personaje muy influyente que participó activamente tanto en el campo de las letras como en la política. Además, éste es autor de una obra múltiple y de carácter popular, leída, en su tiempo, con gran interés y entusiasmo. Sin embargo, hoy en día, es indudable el desvanecimiento literario de este escritor en el canon portugués, ensombrecido, inclusive, por escritores de menor renombre. El principal objetivo de este estudio es mostrar en la trayectoria literaria de Manuel Pinheiro Chagas, los sucesos que, de manera decisiva, contribuyeron al silenciamiento de este hábil polígrafo del canon portugués. Dentro de los cuales ocupa un papel esencial Eça de Queirós, que no sólo consiguió borrar la ilustre participación de Chagas como político, crítico, historiador y prosador en las historias literarias, sino también, redujo la figura de su desafecto, inmortalizándolo en un retrato-sátira de un patriota conservador y reaccionario, bajo el sobrenombre de "Brigadier de la época de D. Maria I".

Palabras llave: Manuel Pinheiro Chagas - Eça de Queirós - Ostracismo Literario Polémicas - Historias Literárias. 


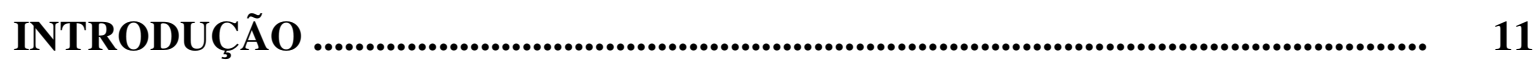

CAPITULO I : POLÊMICA E LITERATURA 15

1.1 Pinheiro Chagas: O homem e o seu tempo .......................................................................... 19

1.1.1 Questão coimbrãa: O início da derrocada da imagem de um polígrafo .................. 25

1.1.1.1 O pomo da discórdia: A crítica ao Poema da mocidade ........................................ 42

1.1.2 Comuna de Paris: Parâmetro ideológico para As Conferências do Cassino ... 56

1.1.3 O Realismo: Projeto revolucionário nas letras ........................................................... 72

CAPITUlO II : PINHEIRO CHAGAS E EÇA DE QUEIROS: ENTRE CONTROVERSIAS PATRIOTICAS E LITERARIAS 85

2.1 Uma querela patriótica: Brasil e Portugal ......................................................................... 90

2.2 A relíquia, um embate literário ........................................................................................ 109

CAPITULO III : CAMPANHAS DE UM DOM QUIXOTE LITERARIO 124

3.1 A crítica de Pinheiro Chagas sob nova perspectiva ..................................................... 128

CONSIDERAÇÕES FINAIS .............................................................................................. 148

REFERÊNCIAS BIBLIOGRAFICAS ................................................................... 152 


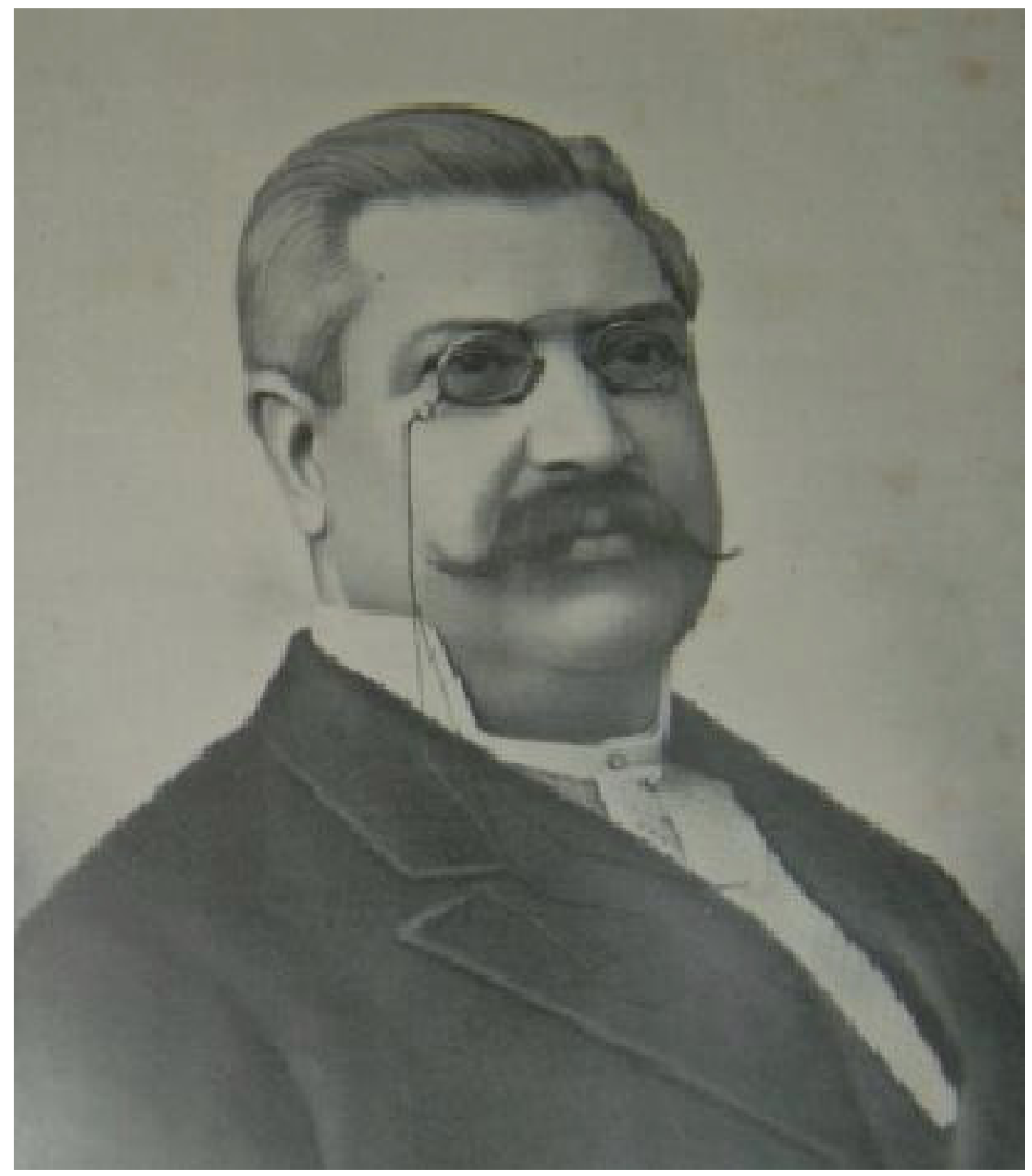

"Conheço que tenho seguido um caminho errado, e vejo finalmente com dor profunda que a posteridade não falará no meu nome senão para o acabrunhar com o seu desprezo. Nunca me remontei, librando-me nas asas da inspiração pindárica, os erguidos cumes do sublime, vejo que andei sempre rastejando, e, percorrendo a longa lista dos meus folhetins, noto com imenso desalento que sempre chamei as coisas pelo seu nome".

(Manuel Pinheiro Chagas, 1865) 


\section{INTRODUCẼ̃O}

Manuel Pinheiro Chagas ${ }^{1}$ (1842-1895), “duvido que este nome diga alguma coisa ao leitor comum ${ }^{2}$ ". Essa frase, estrategicamente aqui colocada, expressa, sem dúvida, uma verdade: se este esteve envolvido em quase todos os principais acontecimentos do seu tempo, ele hoje é pouco mais que um nome. Contudo, Manuel Pinheiro Chagas foi, a partir de 1863, conhecida figura pública de prodigiosa produção, como romancista, poeta, autor teatral, tradutor, crítico literário, historiador, memorialista, cronista. Exerceu, além disso, a função de professor universitário de literatura, oficial do exército, orador, parlamentar, acadêmico, membro do conselho da coroa, membro do conselho superior de instrução pública e ministro da marinha. Como se percebe por meio dessa enumeração sumária, Chagas participou dos diversos setores da sociedade, mas nem toda a sua produção jornalística e literária - que foi consumida com muito entusiasmo em sua época - nem as condecorações que recebeu em vida o impediram de morrer em estado de pobreza.

O objetivo central de nosso trabalho consiste em evidenciar, na trajetória literária de Manuel Pinheiro Chagas, os acontecimentos de sua época que, de forma decisiva, contribuíram para o desaparecimento desse escritor do cânone português. Acreditamos que, nesses acontecimentos, ocupa um papel central Eça de Queirós, que não só conseguiu apagar a participação de Chagas nas histórias literárias, mas também reduziu a figura de seu desafeto, imortalizando-o na caricatura de um patriota conservador e reacionário, sob o codinome de "brigadeiro do tempo de D. Maria I". Eça criou várias alcunhas para Pinheiro Chagas nas polêmicas em que travou com este, como "Brigadeiro Chagas do tempo de D.

\footnotetext{
${ }^{1}$ Aranha, 1893, p.288. Este autor faz referência a um nome mais completo: Manuel Joaquim Pinheiro Chagas.

${ }^{2}$ Ver Pref. Júdice, 1985.
} 
Maria I", "homem fatal" de "curiosidade arqueológica" com "patriotismo ultra-romântico". Como veremos, Eça teve sucesso, pois a imagem que temos hoje de Pinheiro Chagas foi aquela filtrada e deformada pelo seu monóculo irônico e sarcástico. O levantamento bibliográfico desta pesquisa é uma prova disso: não só foi difícil o acesso aos textos de Chagas, como a bibliografia que nos serviu de fonte é, na maioria, referente à crítica passiva sobre o espólio literário de Eça de Queirós.

Muito se discute em José Régio (1945 apud LISBOA, s.d) e José Hermano Saraiva (1979) que esse apagamento de escritores do último quartel do século XIX estaria relacionado ao ofuscamento advindo da genialidade da geração nova. Régio (1945 apud LISBOA, s.d) sugere, retomando uma idéia já defendida por Mário Sacramento, que o excessivo interesse que se dá a todos os feitos da geração de 70 esteja ligado ao fato de terem sido os membros desta, grandes agitadores no levantamento dos problemas de Portugal do século XIX. No entanto, esse crítico adverte-nos que ainda não se deu devida atenção aos possíveis decréscimos causados pela visão particular dessa geração notável, particularmente Eça de Queirós, à imagem do português e à da nação portuguesa. Nosso trabalho de certa forma se baseou nessa premissa, pois não acreditamos que as histórias literárias deram até hoje o devido interesse aos textos de Pinheiro Chagas, sem os conceitos pré-estabelecidos, construídos pela geração de 70, especialmente pelo autor de Os Maias. Para desenvolver essa perspectiva, dividimos a dissertação em três capítulos.

O primeiro é, como se perceberá, a exposição do Portugal literário no segundo quartel do século XIX, sob a influência das idéias do estrangeiro, principalmente da França. Nesse tempo, Portugal era um meio literário pobre e restrito basicamente a dois grupos, que evidenciavam sinais de tensões literárias e rupturas irrecuperáveis, que acabarão por gerar inúmeros embates a partir de então. Portanto, neste capítulo, discutiremos sobre a Questão 
coimbrã, a Comuna de Paris e As Conferências do Cassino, que armam, por assim dizer, o cenário polêmico entre o grupo Antero-Eça e o grupo liderado por Pinheiro Chagas quanto à função da literatura e do escritor, ao Realismo, ao socialismo e ao patriotismo, sendo que esses temas serão, mais tarde, os pretextos para as controvérsias entre Chagas e Eça.

Já no segundo capítulo, trabalharemos diretamente com as polêmicas Brasil $e$ Portugal e A relíquia. Como bem frisou Gaspar Simões (1945), no caso da primeira, estamos diante de dois olhares de uma mesma realidade portuguesa. Ou quem sabe, perante a um diálogo de surdos, em que duas facções se digladiam. Figuravam como ícones desses grupos, respectivamente, Eça de Queirós, depois da ausência de Antero, e Pinheiro Chagas, após a morte de Castilho. A segunda contenda se dá depois do relatório do concurso da Academia que, tendo sido redigido por Chagas, excluiu A relíquia de Eça de Queirós. Polêmica menos política que a primeira, também aqui estaremos diante de duas visões antagônicas, como ficará claro quando a analisarmos.

Por fim, o capítulo terceiro é a reabilitação da crítica de Chagas diante de uma nova perspectiva. Durante toda a nossa discussão apresentaremos apreciações literárias ainda tímidas, como Régio (1945), Buescu (1997), Campos Matos (2001) que se inquietam sobre o ostracismo de Chagas, contudo não abrem muito espaço em seus estudos para uma revisão das obras desse autor. Por outro lado, nesse capítulo, focalizaremos já no tempo de Chagas um texto de Antero de Quental, um dos integrantes da Geração de 70, que ainda no ano de 1872 faz uma análise favorável às observações de Chagas sobre o Desenvolvimento da literatura portuguesa, estudo este que refutara muitas idéias de Teófilo Braga.

Do século XX, trouxemos à luz as observações de Sayers que nos apresentam Chagas como grande incentivador das letras brasileiras em Portugal. Para o crítico norte-americano, o autor do Poema da mocidade fez estudos sensíveis sobre a literatura brasileira, em 
especial sobre Gonçalves Dias, José de Alencar e Machado de Assis, dentre outros. Contudo, o estudo que irá reconstruir e revitalizar, de forma absoluta, outro perfil da crítica de Pinheiro Chagas será o de Abreu (1994). Nesse, sua autora analisa o prólogo sobre Dom Quixote feito por nosso autor, como um dos textos portugueses mais consistentes do século XIX sobre o assunto. O que mais nos surpreendeu na conclusão dessa autora foram suas considerações em ser o texto do autor do Poema da mocidade sobre Dom Quixote uma antecipação de certos aspectos da crítica do século XX.

Como podemos notar, se foi quase totalmente apagado, ou distorcido pelo monóculo do principal romancista da geração de 70, Pinheiro Chagas parece não ser, de fato, um intelectual insignificante. Este trabalho, talvez, sirva para ajudar a recuperá-lo de um ostracismo imerecido. 


\section{Polêmica e literatura}

Raro é o homem de letras e, até mesmo, o homem público que passou a vida sem experimentar a vivência belicosa da polêmica ${ }^{3}$. Em geral, os meios de ataque nesse tipo de contenda foram múltiplos, fruto dos mais diferentes motivos. E algumas, mesmo, transpuseram as páginas do folhetim e terminaram em duelos ${ }^{4}$. Outras situações mais extremas tiveram como desfecho o suicídio de um dos escritores, como ocorreu aqui no Brasil com Raul Pompéia, que se envolvera em uma contenda com Luiz Murat ${ }^{5}$.

Por outro lado, existem aqueles que preferem imortalizar de forma caricatural seus adversários literários em sua ficção, com objetivos claros de evidenciar os seus vícios e, por conseguinte, contribuir no decréscimo do espólio literário dos mesmos. No Brasil oitocentista, por exemplo, destacamos as célebres polêmicas entre Silvio Romero e Machado de Assis, que culminaram em uma crítica antimachadiana de Romero, que passou a vida inteira a explicar sua antipatia pelo autor de Dom Casmurro e a exaltar a genialidade de Tobias Barreto. Segundo Guimarães (2004), o motivo de tanto ódio por parte de Romero poderia estar relacionado aos senões dirigidos à poesia dele em A nova geração (1879), o

\footnotetext{
${ }^{3}$ Cf. Machado Neto, 1973, p.147

${ }^{4}$ Um desses duelos ocorreu entre Antero de Quental e Ramalho Ortigão em janeiro de 1866, no qual Ramalho saiu ferido no braço. Tudo em decorrência ao opúsculo Literatura d' hoje, que se tornou mais um objeto da polêmica Bom senso $e$ bom gosto. Neste texto, seu autor levanta críticas a Castilho, como poeta, como caráter de escritor, como crítico e, por fim, ridiculariza mais uma vez o seu método pedagógico. A Antero censura-lhe, além da covardia, a veleidade de inovação, provando-o como é mau poeta e filósofo. Para Ortigão, as Odes modernas não teriam nada de novo, mas sim tratava-se de uma obra medíocre.

${ }^{5}$ Ver Ventura, 1991, p.144-45. Depois da demissão de Raul Pompéia da Biblioteca Nacional em 1894, sob a acusação de desacato ao presidente Prudente de Morais, Luís Murat aprovou publicamente o seu afastamento, atacando-o de covarde, por não ter duelado com Bilac. Raul de Pompéia escreveu um artigo resposta, mas não conseguiu a sua publicação em nenhum jornal. Desiludido e desmoralizado, Pompéia suicidou-se com um tiro no coração.
} 
famoso texto crítico de Machado de Assis. A resposta daquele vem em uma obra intitulada, Machado de Assis - Estudo comparativo de literatura brasileira. Já na introdução, sem nenhum pudor, Romero deixa claro o seu revide ao afirmar que entre as singularidades das coisas literárias do Brasil está na constante e espontânea produção, por qualquer "mocinho ou rapazelho de novas gerações". A primeira alfinetada, nessa crítica, está na designação "mocinho ou rapazelho", pois Machado de Assis era mais velho que Romero. E, por fim, o emblema de "novas gerações" que, para o crítico brasileiro, não tinha outra conotação senão a ridicularização, pois não se tratava de nada novo, nem moderno, e quem tivesse bom senso deveria desconfiar dessas mudanças de estilo repentinas que certamente eram oportunismos literários. Outro embate literário ocorrido com Machado foi com Cruz e Sousa que o acusara de plágio, vindo, ao auxílio deste, Hemetério dos Santos, a quem na época não bastou atingir o literato, julgando necessário abordar fatos da vida pessoal de Machado de Assis. Para fins ilustrativos, avaliamos ser interessante destacar um trecho dos versos satíricos de Cruz e Sousa dedicados ao autor de A mão e a luva.

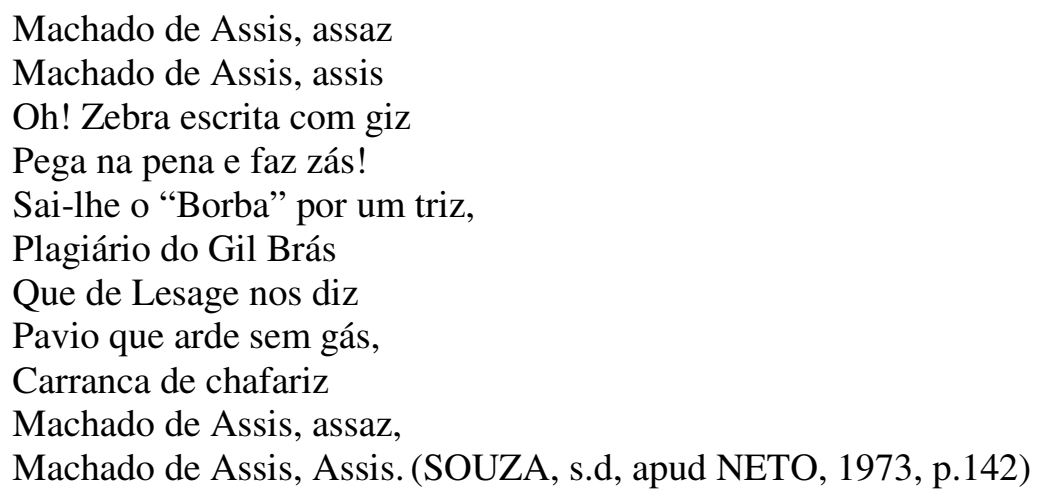

Nesta perspectiva, Machado Neto discute que nas polêmicas ocorridas no Brasil oitocentista, o alvo predileto seria, como de se esperar, os líderes do grupo oficial 
dominante nessa época. E o autor de Memorial de Aires seria um alvo ideal, tanto por sua posição de destaque na cotérie dominante, quanto por sua cor, timidez e origens.

Feita essa observação, entendemos que o cenário literário no Brasil não difere muito do de Portugal quanto às rixas entre escritores. Como exemplo, nesse mesmo período oitocentista, em terras lusitanas, temos Castilho, que figura, durante algumas décadas, como referência no meio literário português, mesmo que essa centralidade fosse, várias vezes, posta em questão. Para Venâncio (1998), a depreciação de Castilho iniciou-se ainda no seu tempo, e assumiu uma forma consistente a partir da polêmica da Questão coimbrã $\tilde{}^{6}$, apesar dessa crítica considerar que desde 1862 este escritor já tinha sido transformado em alvo fácil.

Se a figura de Antonio Feliciano de Castilho tem sido caracterizada de forma apequenada após as querelas que teve com a Geração de 70, entendemos que o mesmo tenha ocorrido com outro escritor, Pinheiro Chagas ${ }^{7}$. Efetivamente, Campos Matos considera que Eça, o principal representante da geração nova que se digladiou com Chagas, imortalizou o seu antagonista através de

uma hábil e espirituosa caricatura, colando indelevelmente à sua figura a imagem de um brigadeiro retrógrado do tempo de D. Maria I. Advirta-se, todavia, que esta imagem, como caricatura que é, tem deformado e diminuído uma personalidade literária e humana mais rica e significativa do que imaginam aqueles que só conhecem dela a versão eciana.(MATOS, 2001, p.340).

\footnotetext{
${ }^{6}$ Ver Venâncio, 1998, p.18-27. Esse estudo destaca que foram decisivos para o ostracismo literário de Castilho nas histórias literárias os textos originários da Questão coimbrã, mais especificamente os de Antero de Quental e Teófilo Braga. Portanto, para nós, foram imortalizadas sobre Castilho as seguintes idéias de Antero (1865, apud Ferreira, 1966, p.225), "não diz nada, nada ensina, não concorre para o movimento geral". Já Teófilo (1865 apud Ibidem, p.193) diz que: "A reputação do Sr. Castilho acaba com a sua vida; é a luz que se apaga consigo; nenhum dos seus livros vai a posteridade, porque a posteridade, sempre impassível, aceita somente o que exerceu uma influência sobre uma época."

${ }^{7} \mathrm{O}$ negativismo que paira sobre a imagem de Pinheiro Chagas nas histórias literárias tem diversas ramificações, sendo a principal, ao nosso ver, as polêmicas em que se envolveu com Eça. No entanto, não podemos desprezar outros fatores, o de ele ser considerado como "delfim" da literatura e crítica de Castilho, ou como o último escritor que cultuou o Ultraromantismo, nem desmerecer o fato de este ter conjugado literatura e política.
} 
Fundamentados nesse parecer de um dos mais conceituados críticos de Eça é que, inicialmente, apresentaremos uma nota biobibliográfica de Pinheiro Chagas. Nosso objetivo constitui recordar a história deste homem que foi para o seu tempo uma das grandes figuras portuguesas, sendo que a sua atividade abrangeu a todos os setores da vida nacional ${ }^{8}$. Contudo, salientamos que essa síntese biográfica não tem um fim em si mesma, seu propósito maior é dar ao nosso leitor todos os subsídios necessários para compreender os desdobramentos do apagamento literário deste escritor que se dá até mesmo no meio acadêmico.

\footnotetext{
${ }^{8}$ Ver Grande Enciclopédia Portuguesa e Brasileira. Vol. XXI, 1945. p. 751
} 


\section{1.}

\section{Pinheiro Chagas: $O$ homem e o seu tempo}

Manuel Pinheiro Chagas ${ }^{9}$ (1842-1895), lisbonense. Foi na sua época personalidade influente, porém hoje é inevitável o ostracismo da sua figura literária. Autor de uma obra vasta que no seu tempo foi lida com grande interesse e até ardor. Fez os seus estudos no Colégio Militar, prosseguindo-os na Escola do Exército e, simultaneamente, na Politécnica. Iniciou a carreira das armas, chegando à patente de capitão, mas entrou logo na inatividade, em que se manteve até 1883, para tomar, em comissão de serviço, o lugar de professor do Curso Superior de Letras.

Literariamente, iniciou a sua carreira em 1863 com o poema $O$ anjo do lar, poesia dedicada à esposa, Maria da Piedade. Foi nesse período também, que estreou na imprensa jornalística, como crítico e folhetinista, na Gazeta de Portugal. Cunha Belém, um de seus contemporâneos, dá-nos impressões valiosas sobre o início de Pinheiro Chagas nos periódicos. Na visão daquele crítico:

Lopes de Mendonça, que empunhara o cetro daqueles domínios, tinha visto apagar-se-lhe a lâmpada da razão, pelo esforço de lucubrações, não superiores ao seu talento, mas avessas à sua índole! Se quiser (sic) obrigar a doidejante borboleta a produzir mel como a laboriosa abelha! Antonio Serpa dera-se fazer mel no cortiço da política; Latino Coelho...esse imitava só da abelha... o fazer cera. Ficara apenas o talento pertinaz e simpático de Júlio César Machado na arena do folhetim. Carecia de um rival que o estimulasse, de um adversário que lhe viesse acender os brios! Pinheiro Chagas levantou a luva, e na Gazeta de Portugal se estreou com os mais prósperos auspícios, que nunca bafejaram as primeiras tentativas de folhetinista algum. Estilo ameno,

\footnotetext{
${ }^{9}$ Esta síntese biográfica tomou como base os estudos apresentados por Brito Aranha (1893), Grande Enciclopédia Portuguesa e Brasileira (1945), Oliveira Martins (1957), Eugênio Lisboa (s.d), Alexandre Cabral (1973) e Campos Matos (1988 e 2001).
} 
pomposo, rico de galas e louçanias, tesouros de erudição enceleirados desde a infância e beneficiados pela clareza do juízo, fina e chistosa crítica e, sobretudo, um bom senso literário e um instinto de bom gosto, admiráveis em tão verdes anos, tudo concorreu para fazer de Pinheiro Chagas um completo escritor desde os seus primeiros passos, sem que nunca lhe coubesse essa blandiciosa e convencional denominação de mancebo esperançoso, dada pela condescendência literária às mediocridades incipientes, que muitas vezes se conservam com o caráter de escandalosa cronicidade. (BELÉM, s.d, apud ARANHA, 1893, p.289)

Os primeiros romances foram publicados em folhetim na Gazeta de Portugal, a começar de 1866 pela Virgem de Guaraciaba que, com A conspiração de Pernambuco, constitui a série de Crônicas brasileiras. A partir desta data, Chagas publicará inúmeros romances históricos até 1878. Em 1865, sai o Poema da mocidade com a célebre e hiperbólica carta-prefácio do visconde de Castilho, suscitando a celeuma que se sabe, e a qual dispensamos um capítulo para sua discussão.

Pinheiro Chagas foi um polígrafo de vastos recursos, pois a sua atividade se distribuiu por trabalhos de índole diversa. Revisou a História de França, de Henri Martin, na tradução de Pedro dos Reis. Escreveu o Prólogo inserto em uma tradução de D. Quixote de Cervantes, obra a que voltaremos. É autor do Prólogo da edição dos Lusíadas empreendida por Duarte dos Santos e Aristides Abranches; esse prefácio foi traduzido em francês por Henri Faure e publicado em separata, em Paris. Dirigiu e foi o principal colaborador do Dicionário popular, nos moldes do Larousse, em dezesseis volumes de grande formato. Escreveu, em português e francês, os artigos descritivos de 24 oleografias editadas por Pedro Correia, nos anos de 1883 a 1885, com o título de Portugal pitoresco, e alguns dos artigos que acompanharam as estampas litografadas do Álbum de costumes portugueses. Da sua autoria são 113 biografias, referentes a sábios, escritores e militares, antigos e modernos, algumas incluídas na coletânea intitulada Portugueses ilustres. 
Na dramaturgia, ele começou a sua carreira com A morgadinha Val Flor, drama em cinco atos estreado em 1869, com enorme êxito, que acabaria por lhe valer a tradução em várias línguas e um monumento na Avenida da Liberdade, em Lisboa, inaugurado em 1908, onde figura a famosa morgadinha. A sua produção foi interrompida em 1875 com a representação do Drama do povo, no teatro de D. Maria II. Nesta época, o público manifestou desagrado por acreditar que a peça era um ataque à realeza. Este infortúnio levou o dramaturgo a se afastar do teatro por dezenove anos. Sendo que o seu último trabalho teatral foi a comédia Lição cruel, em três atos, representada em 1894, no teatro do Ginásio.

A sua atividade como tradutor conta com mais de sessenta títulos, entre romances e peças de teatro. No domínio da crítica literária, publicou Ensaios críticos (1866) e Novos ensaios críticos (1867) nos quais analisa a iniciativa literária de prosadores e poetas portugueses, brasileiros, italianos e espanhóis. E, algumas dessas opiniões acerca da Literatura Brasileira ${ }^{10}$ foram contraditadas num folhetim inserto no jornal A reforma, do Rio de Janeiro, em 7 de novembro de 1869. Teve grande interesse pela instrução do povo e seguindo as idéias da sua época, foi um grande divulgador, principalmente da história, colaborando ativamente na coleção de educação popular, onde publicou: Aljubarrota, $O$ Marquês de Pombal, A guerra peninsular, História da guerra entre a França e a Prússia, etc. Vale citar que a história ultramarina também lhe mereceu alguns estudos. Foi, além disso, redator e colaborador de inúmeros periódicos, dentre os quais podemos citar: Gazeta

\footnotetext{
10 Ver Melo, 1972, p.11-29. Pinheiro Chagas se envolvera em uma polêmica acerca da Literatura Brasileira com José de Alencar. Nessa controvérsia, Alencar, no pós-escrito à segunda edição de Iracema, responde as críticas de Chagas presentes no artigo Literatura Brasileira - José de Alencar, reunidos em Novos ensaios críticos (1867, p.221), sobre a tendência alencariana de fazer do português do Brasil diferente ao de Portugal. Chagas comenta: “[...] vejo em todos os livros brasileiros, e contra o qual não cessarei de bradar intrepidamente, é a falta de correção na linguagem portuguesa, ou antes, a mania de tornar o brasileiro uma língua diferente do velho português, por meio de neologismos arrojados e injustificáveis, e de insubordinações gramaticais [...]". A réplica de Alencar no referido pós-escrito sugere que não seria a formação de um novo idioma, mas o aperfeiçoamento do português. Para Alencar, diferentemente de Chagas, isso não implicava em decadência.
} 
de Portugal, Jornal do comércio, Diário popular, Revista ilustrada e Diário da manhã, substituído posteriormente por Correio da manhã..

Foi talvez como historiador que alcançou maior notoriedade ao publicar em fascículos, entre 1867 e 1874, como principal colaborador, a História de Portugal desde os tempos mais remotos até a atualidade, obra composta por "uma sociedade de homens de letras" ${ }^{11}$, segundo o plano de Ferdinand Denis ${ }^{12}$. Sete anos mais tarde, essa obra daria lugar, revisada e aumentada, à História de Portugal. Em 1880, Pinheiro Chagas publicou a História alegre de Portugal e Resumo da história de Portugal, adotado oficialmente nos liceus; em 1890, A Descoberta da Índia contada por um marinheiro e, em 1893, Migalhas de história portuguesa.

Como estadista, filiou-se ao Partido Regenerador que o fez deputado à primeira vez, pela Covilhã, em 1871, e desde então foi eleito para todas as legislaturas até 1892, apenas com um interstício de seis meses, causado por uma forte oposição do Partido Progressista. Em 1883, foi nomeado ministro da Marinha, no ministério de Fontes Pereira de Melo, tendo-se exonerado desse cargo em 1886. Promoveu, no tempo do seu ministério, o desenvolvimento de infra-estruturas nas colônias de Angola, Moçambique e Cabo Verde. Além disso, incentivou a colonização do interior de Angola, na província de Namibe (antiga Moçâmedes).

\footnotetext{
${ }^{11}$ Ver Queirós, s.d., vol. II, pp.1410-411. Eça, ao depreciar a História de Portugal de Pinheiro Chagas na polêmica Brasil e Portugal, ridiculariza a forma com que este denomina a autoria da sua História de Portugal como "obra composta por uma sociedade de homens de letras", já que essa tinha um único autor, Pinheiro Chagas: "[...] e desta curiosa frase, deduzi, como todo o mundo deduziria, que alguns literatos tinham compilado uma dessas histórias anedóticas e populares, que publicam as Bibliotecas recreativas, e que você fora encarregado pelo editor de planear, dirigir, rever a compilação. [...]vejo que cometi um erro abominável. Você, com efeito, escrevera uma verdadeira História de Portugal, sob o numeroso pseudônimo duma "Sociedade de literatos", justamente como se pode publicar um poema sob este pseudônimo múltiplo: "As onze mil virgens", ou uma opereta por "Uma Sociedade Filarmônica."

${ }^{12}$ Cf. Sérgio Campos Matos, 1998, p.21. A obra de Ferdinand Denis, renomado historiador e bibliotecário parisiense, foi bem acolhida pelos historiadores portugueses, tornando-se uma influência na criação da História de Portugal (1867) de Pinheiro Chagas.
} 
Pinheiro Chagas também ocupou os cargos de secretário-geral da Academia das Ciências, de vogal do Conselho Superior da Instrução Pública, presidente da Junta de Crédito Público e presidente da Associação dos Homens de Letras. Recebeu inúmeras distinções, como a nomeação vitalícia de par do reino, titular das comendas e grã-cruzes das ordens de D. Carlos III de Espanha e de Leopoldo da Bélgica e, ainda, o grau de grande oficial da legião de Honra de França.

Não obstante, a sua popularidade e êxito ficaram evidentes a partir de um plebiscito literário promovido em 1884, pelo Imparcial de Coimbra. Vale lembrar que, nessa época, os progressos estéticos e a modernização literária imposta através do romance naturalista não conseguiram - mesmo no auge da produção realista e naturalista de Eça de Queirós mudar a opinião literária do público luso-brasileiro. O resultado final desta pesquisa literária, que contraria o momento estético em destaque, posicionou nos primeiros lugares dois escritores tidos como ultra-românticos pelas histórias literárias, Camilo Castelo Branco em primeiro e Pinheiro Chagas em segundo lugar ${ }^{13}$.

Em 7 de fevereiro de 1888, Pinheiro Chagas foi atacado à bengalada por um anarquista, em plena rua, à saída do Parlamento, agressão que o deixou muito abalado e em perigo de vida. Este ataque fora em represália às palavras chistosas e depreciativas que Chagas dedicara, no diário lisboeta $O$ repórter, a Louise Michel, heroína socialista da Comuna de Paris ${ }^{14}$. Oliveira Martins (1957 [1888], p.181), no dia seguinte, publicava nesse mesmo jornal a condenação do atentado, referindo-se a vítima como "um escritor que nas

\footnotetext{
${ }^{13}$ Ver Cabral, 1973, p.589. O resultado final das respostas enviadas pelos leitores luso-brasileiros de $O$ imparcial de Coimbra colocaram Eça de Queirós em quarto lugar, Teófilo Braga em sexto, Oliveira Martins em sétimo e Antero de Quental em décimo-segundo.

${ }^{14}$ Esse artigo saiu cinco dias após o atentado sofrido por Louise Michel durante um comício no Havre no dia vinte de janeiro de 1888 .
} 
letras pátria está na primeira fila”. Por essa altura, Eça polemizava novamente com ele, desta vez a propósito do concurso da Academia, a que concorrera com A relíquia.

Pinheiro Chagas viria a falecer em Lisboa, em 8 de abril de 1895. Contudo, todos os seus cargos, a sua vasta produção literária e as inúmeras homenagens que recebeu em vida não o impediram de morrer em estado de pobreza.

Nas palavras de Campos Matos (1988), as relações de Eça ${ }^{15}$ com Pinheiro Chagas começaram, presumivelmente, por ocasião da campanha de oposição aos representantes da nova geração de Coimbra, Teófilo Braga e Antero de Quental, no Jornal do comércio, em 1865. Destaca também que muito embora Eça não tenha participado diretamente na contenda da Questão coimbrã ${ }^{16}$ - este a acompanha como observador e admirador de Antero. Dessa maneira, devemos antecipar que os temas que discorreremos a seguir sobre a Questão coimbrã, A Comuna de Paris e As Conferências do Cassino serão decisivos para a construção da imagem reacionária e regressiva que a Geração de 70 terá de Pinheiro Chagas.

\footnotetext{
${ }^{15}$ Será necessário recorrer durante a nossa discussão a várias obras de Eça, assim, optaremos por citá-las através das seguintes siglas: NC: Notas Contemporâneas; UCA: Uma Campanha Alegre; CI: Cartas de Inglaterra; OM: Os Maias; CIFM: Cartas Inéditas de Fradique Mendes e Mais Páginas Esquecidas; CO: Correspondência e, finalmente, AICR: A Ilustre Casa de Ramires.

${ }^{16}$ Ver Carlos Reis, 2001, p.52. Esse crítico salienta que essa polêmica - que durou um ano inteiro e envolveu dezenas de personalidades literárias, entre elas Camilo - deu-se entre duas gerações românticas visivelmente separadas por suas concepções socioliterárias.
} 


\subsection{1}

\section{Questão coimbrã : $O$ início da derrocada da imagem de um polígrafo.}

A primeira posição a ser tomada quando se procura a revisão de algo é libertar-se, mesmo que por algum tempo, das imagens estereotipadas, das frases feitas com que nos tem sido apresentado qualquer tema, aqui particularmente a célebre polêmica, a Questão coimbrã, também denominada Questão do bom senso e do bom gosto. É fato, e logo mais veremos, que algumas informações equivocadas e mimetizadas sobre essa contenda ainda sobrevivem em alguns espaços das histórias literárias. Uma delas é caracterizar a Questão coimbrã primordialmente como uma polêmica literária. ${ }^{17}$ Aliás, já em 1966, Alberto Ferreira procedeu a uma revisão lúcida desta querela, mostrando que nela a questão literária ocupava um lugar relativamente modesto, e que, na realidade, tratava-se de uma oportunidade em se discutir a própria estrutura da nação. Esta postura de Alberto Ferreira, que já estava presente nos comentários de Eça em In Memoriam (1895), será a mesma de vários estudos posteriores, como, por exemplo, o de Campos Matos (1988). O autor de $O$ primo Basílio afirmou em seu texto em homenagem a seu companheiro de geração:

Seriam hoje úteis, entre nós, um ou dois Castilhos, o vetusto árcade mostrou intolerância e malignidade, deprimindo e escarnecendo dois escritores moços, portadores de uma idéia e de uma expressão próprias, só porque eles as produziam sem primeiramente, de cabeça curva, terem pedido o selo e o visto para os seus livros à Mesa Censória, instalada sob a seca olaia do seco cantor da Primavera. O protesto de Antero foi, portanto, moral e não literário. (QUEIROS, $N C$, s.d., v.II, 1896, p.1546)

\footnotetext{
${ }^{17}$ Ver Hess, 1978, p.96. O princípio ético da responsabilidade individual foi defendido por Antero e sugere que a literatura constituía tão somente o veículo de renovação moral.
} 
Este trecho confirma-nos a proposição dos dissidentes de Coimbra em tornar coadjuvantes os aspectos literários em relação aos motivos ideológicos e morais. Por exemplo, Antero concentra-se em duas vertentes, a primeira, na defesa da dignidade e independência do indivíduo e, a segunda, na necessidade de uma renovação moral da sociedade. Não era, portanto, o Romantismo ou o Ultra-romantismo de Castilho e de seus aliados a verdadeira causa da Questão coimbrã. Contudo, esta idéia é reforçada em alguns estudos que acreditam que a partir da Questão coimbrã foi estabelecida a sobreposição de estéticas. Autores, como Sampaio, incorrem nesse erro ao afirmar que essa querela seria a dissolução geral do Romantismo e o início do Realismo. Isto é, uma literatura "que morria e a outra que bravamente queria tomar o seu lugar ao sol" (SAMPAIO, s.d, p.186). Diferentemente deste, Reis (2001, p.42) sinaliza que a "Questão coimbrã foi principalmente uma querela entre concepções distintas de literatura em tempo de Romantismo”. Seguindo essa lógica, é difícil não acreditar que esta polêmica foi um pleito entre duas formas diferentes de pensar e de encarar a literatura ${ }^{18}$, e não uma contenda literária travada entre o Realismo nascente e o Romantismo decadente. Dessa maneira, como bem observa Reis (2001), a polêmica mais importante da literatura portuguesa não foi suficiente para estabelecer o advento do Realismo, que tempos depois terá sua demarcação nas Conferências do Cassino (1871). ${ }^{19}$ Importa-nos, ainda, esclarecer que naquela época, os jovens intelectuais, que nessa altura se formavam principalmente em Coimbra, estavam longe de se apresentarem contrários às correntes do Romantismo. Pelo contrário, Eça de Queirós $^{20}$, Batalha Reis, Antero e outros tantos afirmaram explicitamente a sua simpatia

\footnotetext{
${ }^{18}$ Cf. Simões, s.d , p.27

${ }^{19}$ Ver Mendes, 1997, p.457 Para essa autora, a Questão coimbrã expressou mais um surto de Romantismo nacional, multiforme e inesgotável. Como também define França (1992) ao considerar que foi uma luta entre dois Romantismos.

${ }^{20}$ Ver Ferreira, 1966, p.378. Eça chegou mesmo a afirmar que "Naqueles tempos, segundo a fórmula do Evangelho, o Romantismo estava nas nossas almas. Fazíamos devotadamente oração diante do busto de Shakespeare.”
} 
pela literatura romântica. E o fruto deste espírito romântico deu-nos, dentre outras obras, as Prosas bárbaras de Eça de Queirós.

Como norteadores em nosso estudo quanto ao Romantismo em Portugal na época da Questão coimbrã, privilegiaremos as idéias de Antonio Sérgio (1978) que já refutara essas concepções simplistas sobre a decadência do Romantismo e ascensão do Realismo com essa polêmica. Para este crítico (1978), o Romantismo desenvolveu-se em três fases distintas: a primeira geração compreendida entre 1825 e 1851, a segunda entre 1851 e 1870 , denominada Ultra-romântica e a terceira que sobreviveu paralelamente com o Realismo e sem data fiel de extinção. Lembramos que não será nosso propósito tratar de forma específica as duas fases que não atingiram o período da Questão coimbrãa, ou seja, a primeira e a terceira fases do Romantismo. E ao fazermos uma recapitulação do panorama estético da época, não pretendemos obviamente uma reconstituição de todos os pormenores. Apenas nos interessam os acontecimentos principais, na medida em que estes foram decisivos para a ocorrência da Questão coimbrã e, de outro lado, para a reprodução nas histórias literárias de uma imagem redutora e caricatural de Pinheiro Chagas, favorecendo assim a sua exclusão do cânone português.

A segunda fase romântica, denominada Ultra-romantismo, surge sob o imperialismo do Romantismo sentimental e do regresso ao passado medieval. Esse termo teria sido criado, em 1832, por Antonio Feliciano de Castilho como representatividade do estilo declamatório $^{21}$. Por outro lado, só em 1892, a designação Ultra-romantismo foi introduzida nos estudos literários de Teófilo Braga, um dos integrantes da Geração de 70, de forma

\footnotetext{
${ }^{21}$ Cf. Rodrigues, 1997, p.563. As histórias literárias consideram que o neologismo Ultra-romântico teve a sua primeira ocorrência em uma carta de Castilho a Vitorino Freire Cardoso da Fonseca na data que apresentamos.
} 
mais sistemática e abrangente ${ }^{22}$. Nestes, ele torna ainda mais preciso cronologicamente o conceito de Ultra-romantismo, desenvolvendo-o a nível teórico e mesmo comparativista, a partir de idéias políticas e sociais. De acordo com Braga, essa classificação representaria um tipo de literatura voltada para a Idade Média. Braga considera ainda que a exageração estilística, uma das características dessa estética, deve-se principalmente à exploração de uma única temática, por meio da ênfase retórica. Para o autor d'As Tempestades sonoras, em Portugal, dois fatores contribuíram para a degeneração ultra-romântica, a falta de uma educação científica da mocidade e o conflito das ambições políticas que desorientavam os novos talentos para o jornalismo.

Vale ressaltar que o estudo de Machado (1986) toma como base as idéias de Teófilo Braga presentes em sua obra A História da literatura portuguesa. Para Machado, a primeira geração teve sempre norteada por um Romantismo liberal militante, caso, sobretudo, de Herculano, enquanto que a segunda geração distanciou-se das lutas políticas e sociais, privilegiando um Romantismo macabro, ditado por um nacionalismo decadentista. Em resumo, a estética romântica aqui está distante dos fatos públicos, o seu interesse está na busca do passado, de caráter intimista, pessoal e subjetivo ${ }^{23}$.

Por seu lado, Braga (1892) baseia sua teoria quanto à obra dos Ultra-românticos à luz das idéias de Barbe Gendre que considerava que o caráter de um escritor é determinado pelas condições do seu meio e do seu tempo. Ou seja, seria determinante em sua literatura a

\footnotetext{
${ }^{22}$ Ver Braga, 1871, p. 272-290. Curiosamente, em sua obra História do teatro português, no capítulo sobre Ultraromantismo, Teófilo Braga não faz nenhuma referência a Pinheiro Chagas e nem a sua famosa peça teatral, A morgadinha Val Flor (1869). Nesta, ele cita Mendes Leal e Rebello da Silva, respectivamente herdeiros de continuar as obras de Garrett e Herculano. Na concepção de Braga, ambos eram incapazes de compreender a importância do legado literário que lhes foram entregues, preferindo cooperarem na corrupção política instalada em Portugal. Dessa maneira, para esse crítico, Mendes Leal e Rebello da Silva eram espíritos que se aproveitavam dos períodos de decadência em prol de seus interesses.

${ }^{23}$ Ver Ferreira, 1866, p.99. Para esse autor, apenas dois escritores de talentos conseguiram sobressair nessa fase: Rebelo da Silva e Soares de Passos. Estão presentes nessa estética a "época do pranto, do cemitério, do cipreste, das bruxas e das santas violadas, das virgens pálidas, de amores contrariados, das noites terríficas, nevoeiros, ansiosas fugas para os céus infinitos, pesadelos cósmicos."
} 
atmosfera moral que ele respirava. Daí o fato de Teófilo Braga (1892) relacionar a literatura desse período como a possibilidade para escritores menores ocuparem cargos públicos. Para ele, participaram dessa corrente literatos, que desperdiçaram faculdades poderosas num jornalismo de fachada e de oposições contraditórias no parlamentarismo. Assim, a atividade jornalística e literária servia para os oportunistas da época realizarem uma ambição comum entre os escritores medíocres, o de ser ministro. Braga não esquecera que associado a essas duas práticas literárias tinha também a oratória parlamentar que ajudaria em satisfazer:

[...] a vaidade pessoal de serem ministros, exercendo o poder executivo sem plano, em um exagerado formalismo centralista, e pela sua própria inércia entregando-se em todo o peso das mediocridades atrevidas a um conservantismo vergonhoso. (BRAGA, 1892, p.168).

Dessa maneira, a glorificação do escritor nessa época estava muito mais associada à sua oratória parlamentar e atuações de estadista do que a grandeza de sua obra. Como podemos observar nesse fragmento do texto de Braga, essa prática literária, com a finalidade de concretizar as aspirações políticas das personalidades desse tempo, empobrecia não só o governo monárquico-constitucional como também o meio literário.

Oliveira Martins ([1881] 1981) na sua obra Portugal contemporâneo nomeia o Ultraromantismo como neo-Romantismo. Este historiador faz referência aos escritores, Pinheiro Chagas e Tomás Ribeiro, e também às relações entre literatura e estado, considerando que essa estética relaciona o: 
burocrático e piegas, artificial, sem raízes no coração de uma gente prosaica ou devassa; o chefe desse Romantismo cujos derradeiros foram Chagas e Tomás Ribeiro com o D. Jaime e a secretaria da Marinha, com a Morgadinha e uma política sempre infeliz; o chefe de uma escola arrebicada e petulante, foi Castilho - um velho Fontes da poesia. Ao seu temperamento feminino ou infantil agradavam as mansas ternuras simuladas dos Byron do Terreiro - do - Paço; e se lá no fundo tinha uma ironia aguda para os crivar de epigramas antigos, vingando-se: não poderia deixar de os lisonjear, de os acolher, de os encher de louvores e mimos, - chamando isto a um, aquilo a outro: um congresso de gênios! (MARTINS, [1881]1981, p.363).

Os textos de Oliveira Martins e Teófilo Braga têm o mesmo tom ao discutir a literatura Ultra-romântica. Sendo que a recuperação de algumas considerações de Oliveira Martins sobre o Ultra-romantismo como espelhamento do Portugal decadente se dará, no século XX, através dos textos de Antonio Sérgio (1978), um dos mais dedicados estudiosos de alguns integrantes da Geração de 70. Nesse estudo, seu autor considera Castilho como uma espécie de fontismo da literatura, líder de uma roda literária que ambicionava apenas promoções políticas.

O fato das histórias literárias generalizarem o Ultra-romantismo como uma estética de medíocres literatos que participavam do meio literário apenas como meio de angariar cargos públicos, possivelmente, tenha excluído muitos escritores do cânone português. Iremos dialogar, agora, com um crítico que observou em algumas obras rotuladas como Ultra-românticas qualidades, até então, despercebidas pela maior parte da crítica. Hess (1978) considera que Paquita de Bulhão Pato, tida como uma produção Ultra-romântica, tem princípios artísticos que subvertem a definição dessa estética apresentada por Teófilo Braga $^{24}$, como, por exemplo, o humor romântico. Para este crítico alemão, Paquita constitui "uma paródia da poesia do amor romântico sentimental, uma paródia das

\footnotetext{
${ }^{24}$ Correspondem as características essenciais da definição de Teófilo Braga, o traço do exagero, o sentimentalismo e as degenerações das concepções românticas. Dessa maneira, a definição de Ultra-romantismo estabelecida pelos estudos desse autor não contempla o traço do humor.
} 
aventuras dessa figura mítica do Romantismo que é Don Juan. O elemento parodístico encontra-se desde logo contido no humor romântico ${ }^{25, "(H E S S, ~ 1978, ~ p .28) . ~}$

Este fragmento sintetiza claramente que Paquita seria uma obra duplamente irônica que parodia o próprio sentimentalismo do autor como também satiriza a poesia Ultraromântica, enquanto gênero literário. Outra obra contemplada pela análise de Hess (1978) é o Poema da mocidade ${ }^{26}$ de Pinheiro Chagas. Em suas considerações, Hess aponta que apesar das deficiências de construção desta obra e de ser possível encontrar um elevado grau das características enumeradas por Teófilo Braga quanto à conceituação de Ultraromantismo, não se pode desmerecer o traço do humor romântico presente nesse livro, principalmente, na construção de duas personagens, especificamente os pais de Ema. Para Hess (1978), a aproximação desse poema ao modelo de lírica sentimental Ultra-romântica está no exagero da moralidade, das paixões e na religiosidade lacrimejante. Mais adiante em suas explanações, Hess entende que existe a necessidade de uma reavaliação desta estética no sentido de considerar "o Ultra-romantismo como categoria descritiva e não de valorização negativa, ao contrário do que fez Teófilo Braga”27 (HESS, 1978, p.29).

Outra marginalidade imposta a esse período estético é considerá-lo como uma época sem qualquer tipo de espírito revolucionário. As histórias literárias negligenciam que,

${ }^{25}$ Cf. Hess, 1978, p.93. Madame Staël e Lopes de Mendonça já tinham proposto uma conceituação do que seria este tipo de humor. Para Staël, "o conceito de humor só se torna perfeito quando alia também ao riso, ao burlesco, à sátira, ou seja, a gaité, o enfadamento, a postura sorumbática (morosité) e quase tristeza (tristesse), produto da disposição sombria (disposition sombre) do autor".

26 Ibidem, p.81. Nesse estudo, seu autor considera que Pinheiro Chagas tinha conhecimento do sentimentalismo exacerbado e do caráter altamente moralizante de sua obra, que certamente viria a opor-se a literatura utilitarista de seu tempo.

${ }^{27}$ Cf. Prado Coelho, 1969, p.119-121. Teófilo Braga não deixou de privilegiar e influenciar nos seus juízos literários o biografismo dos escritores ligados ao meio político, nem demonstrou imparcialidade quanto a "simpatias e antipatias pessoais". Para ele, a crítica literária de Teófilo Braga é mal elaborada, negligente e submetida a uma escrita frenética. 
durante o período de $1846-1848^{28}$, houve um curto período de grande efervescência socialista na literatura Ultra-romântica advinda das revoluções nacionais e européias.

Nos anos de $1850-1851^{29}$, alguns intelectuais progressistas abandonam a bandeira liberal e se voltam para o socialismo. Contudo, esse amor seria fugaz, com o retorno de muitos deles à perspectiva anterior, visivelmente arrependidos - pois seriam "necessárias muita coragem e loucura para agüentar o bloqueio burguês à obra escrita sob a inspirada generosidade humanitária, suportar as dificuldades materiais e morais criadas aos escritores” (FERREIRA,1966, p.99). Por outro lado, será aqui neste entremeio que o "dramalhão social" ganha o gosto popular e a poesia tem seu auge quanto ao sofrimento popular, desigualdades e injustiças sociais ${ }^{30}$. Tal mudança de perspectivas no movimento romântico coincide com o entusiasmo provocado pelos ideais revolucionários dos socialistas utópicos: Saint-Simon, Fourier, Louise Blanc, Proudhon e etc. Apesar disso, o conteúdo romântico das obras não se altera, persistindo a mesma atitude exagerada quanto ao sentimentalismo piegas e os excessos do convencionalismo amoroso.

A literatura produzida no período Ultra-romântico, classificada sarcasticamente como literatura oficial ${ }^{31}$, tinha como figura central Antonio Feliciano de Castilho. Reis (2001) estabelece que o vazio cultural na época da Regeneração favoreceu o brilhantismo de

\footnotetext{
${ }^{28}$ A Guerra da Patuléia (1847) foi uma Guerra Civil desencadeada em Portugal, após a Revolução da Maria da Fonte e a ela estreitamente associada, pela nomeação, na sequiência do golpe palaciano de 06 de outubro de 1846, conhecido pela Emboscada, de um governo claramente cartista presidido pelo marechal João Oliveira e Daun, Duque de Saldanha. Essa Guerra Civil durou oito meses, opondo os cartistas (com o apoio da rainha D. Maria II) a uma coligação inusitada que juntava setembristas a miguelistas. A guerra terminou com uma clara vitória cartista, materializada a 30.06.1847 pela assinatura da Convenção de Gramido, mas apenas após a intervenção de forças militares estrangeiras ao abrigo da Quádrupla Aliança. (Cf. Serrão, 1992, p.16-20).

${ }^{29}$ Cf. Ferreira, 1966, p.99. Nessa fase, a vida política era compartilhada por três facções: os reacionários ligados à ditadura cabralistas, os setembristas ligados aos socialistas utópicos e os regeneradores.

${ }^{30}$ Ibidem, p.100. Essa literatura foi diretamente influenciada por George Sand, pelo romance de intenção social de Lamartine, Eugênio Sue, Heine, Beránger e Victor Hugo.

31 Ver Reis, 1990, pp.28-29. Literatura oficial, num sentido que importa clarificar, trata-se de um fenômeno que se encontra próximo da chamada literatura de partido; em ambos os casos, verificam-se que o escritor abdica de uma parte substancial da sua liberdade e aceita divulgar nas suas obras valores que sintonizam com um determinado status quo dominante. Dessa forma, a literatura oficial decorre em linha direta de uma acomodação do escritor a um sistema políticocultural determinado, colhendo dele os benefícios que outrora cabiam à proteção dos mecenas. E é nessa dependência cultural e mental que se encontra o escritor e o faz perder a capacidade crítica.
} 
Castilho que a sua pouca qualidade literária não fazia por merecer. Como ainda nos informa Reis, Castilho era o protetor da moral vigente, determinava o bom gosto literário, aprovando a moda dos prefácios protetores ${ }^{32}$. Não foi à toa que a sua volta formou-se um grupo de jovens escritores que necessitavam de sua aprovação para ingressarem nesse meio literário tão restrito. Esse tipo de apadrinhamento foi criticado e apelidado por Antero mais tarde na Questão coimbrã como Escola ou Sociedade do elogio mútuo. ${ }^{33}$

Relembremos, então agora, os episódios que antecederam a referida contenda e que foram imprescindíveis para a sua eclosão.

A primeira grande manifestação de descontentamento e afronta perante a supremacia artística de Castilho surge em 1862 com a publicação do poema D. Jaime de Tomás Ribeiro. Teria sido a Conversação preambular feita por Castilho, e não a epopéia romântica a desencadear uma controvérsia, precedente da polêmica de 1865 . O tema do referido prefácio é a desvalorização d' Os Lusíadas de Camões e a promoção do poema de Tomás Ribeiro. Esta apresentação crítica de Castilho está intrinsecamente ligada ao fato, como aponta Reis, de que

[...] a literatura Ultra-romântica é motivada por propósitos ao mesmo tempo de ordem pedagógica e de ordem decorativa. De ordem pedagógica, porque, na decorrência da herança do primeiro Romantismo, a poesia surge na sociedade burguesa e liberal pretendendo ser fator de progresso moral: por isso Castilho recomendou a leitura de D. Jaime de Tomás Ribeiro nas escolas. (REIS, 1993,p.250)

\footnotetext{
${ }^{32}$ Ver Ferreira, 1966, p.105. Castilho era " brilhante no improviso, de verbo quinhentista e abundante, os seus discursos prefaciais eram disputados pelos estagiários da 'glória poética' - eufemismo que significava comezinhamente o aplauso guloso da nossa burguesia lírica."

${ }^{33}$ Nem todos os escritores do período cabem nessa divisão. Segundo os estudos de Oliveira (2005), é o caso, por exemplo, de Camilo Castelo Branco, que acaba por ser quase esquecido em várias histórias literárias, como a História crítica da literatura portuguesa.
} 
Apesar das razões apresentadas e fundamentadas por Castilho, de acordo com Hess (1978), aquele não conseguiu persuadir ninguém e não faltaram reações de indignação no meio literário. A obra recebeu elogios, mas também críticas, sobretudo, dirigidas ao texto de Castilho. Vale lembrar que, nessa polêmica acerca de D. Jaime ocorrida no período de 06 de agosto a 10 de outubro n' A revolução de setembro, participaram Ramalho Ortigão ${ }^{34}$ e João de Deus criticando a obra e, favoráveis a ela, entre outros, Cunha Belém, Pinheiro Chagas que desempenhará um papel de relevo ao lado de Castilho em todas as polêmicas, Júlio César Machado e Palmeirim. Todas estas personalidades produziriam mais tarde folhetos, artigos e comentários na polêmica de 1865 .

Nessa época, Coimbra era o núcleo da efervescência intelectual e da agitação estudantil e a França era o modelo de todas as tentativas de modernidade nos setores, literário, político e social. Em 1863, um dos fatores que contribuiu para uma circulação mais rápida e mais constante da informação estrangeira foi certamente a ligação de Portugal à rede ferroviária espanhola que tinha uma comunicação direta com a França. E foi a partir disso que se deu mais facilmente o internacionalismo político, social e literário ocorrido em muitos artistas revolucionários da época de 1865, representando mais uma etapa da secular dependência cultural de Portugal em relação à França.

Contrariamente ao que parece, antes do início da Questão coimbrã, houve uma aparente e transitória harmonia entre os dois grupos de literatos. Todas as rixas de até então pareciam ter sido apaziguadas. E o exemplo maior deste período de paz, dado por Ferreira (1966), é a saudação elogiosa de Pinheiro Chagas publicada no Arquivo pitoresco sobre o poema Visão dos tempos de Teófilo Braga.

\footnotetext{
${ }^{34}$ Ver Ferreira, 1966, p.107. Ortigão como um dos mais fervorosos adversários da crítica literária de Castilho, chega mesmo a afirmar que: "se esta epopéia não fosse uma ficção, seria uma lamentosa vergonha nacional que cumpria atabafar”. Esses dizeres representavam a discordância de Ortigão acerca da recomendação do D. Jaime com fins pedagógicos.
} 
[...] uma individualidade vigorosa que se desviando da senda por onde caminhava a compacta legião dos nossos poetas, seguindo escrupulosamente a pisada dos mestres, abrisse vereda nova, e imprimisse o cunho da originalidade nas produções do seu gênio. [...] já vêem, pois os meus leitores que Teófilo Braga é vulto muito notável, destinado a ocupar um lugar eminente entre os nossos escritores e, o que é talvez melhor ainda, um lugar à parte. (CHAGAS,1864 apud FERREIRA,1966,p.112)

Na visão do crítico do século XX, Chagas reconhece a audaciosa tentativa de Teófilo Braga em poetizar a filosofia e a estética históricas, estilo muito próximo de suas concepções literárias neoclássicas, principalmente a primeira parte, a Antigüidade homérica. Já as duas últimas partes, consideradas como "modernas", merecem-lhe apenas um assentimento hesitante. Pinheiro Chagas, sem perder o sentido das realidades nacionais, distancia-se com palavras cautelosas e reconhece que a Visão dos tempos seria necessariamente uma obra destinada a uma minoria, devido ao seu grau de dificuldade ideológica e estilística. E conclui que:

Portugal não é grande bastante para que cada poeta tenha um público. É necessário agradar a um só, cujo gosto e instrução não estão incontestavelmente à altura do gênio de Teófilo Braga. Se a literatura portuguesa ocupasse um lugar determinado e fixo na literatura européia, se as lucubrações dos nossos gênios pudessem ser apreciadas pelos estrangeiros. Teófilo Braga seria de certo, em o seu talento se aperfeiçoando mais um dos que chamariam a atenção do público ilustrado da Europa. (CHAGAS, 1866, p.74-75)

A partir das reflexões críticas de Chagas, Hess supõe que este não concebia que o público pudesse ter a capacidade de modificar o gosto e elevar a sua cultura pelo simples contato com uma obra inovadora. Assim, a crítica de Chagas entende que as tentativas renovadoras dos dois escritores da nova escola tinham como denominador comum a característica do extraordinário, apresentada com a intenção de perturbar o público da 
época, chamando-lhe assim a atenção para outras possibilidades da literatura, que não as tradicionais.

[...] O estilo, leitor, é a grande preocupação da literatura contemporânea, ou antes, da literatura portuguesa. [...] Palavreado! Nisso atualmente se está resumindo a nossa literatura! [...].

E sabe de quem é a culpa? É sua. Espanta-se, caro leitor, pois é esta a pura verdade. É sua e dos seus colegas; é do público, enfim. Pois não lhes tenho eu ouvido dizer mil vezes: "Fulano é um grande escritor; não tem ideal, não tem graça, não tem sentimentos, não tem finura de observação, mas é um grande estilista”. [...] Amontoar palavras pomposas que nada exprimem, diluir em frases uma idéia banal, repetir mil vezes um pensamento, exprimindo-o com mil sinônimos, já que, para desgraça nossa, temos uma língua tão rica que estes perdulários podem enterrar os braços no cofre maravilhoso dos seus vocábulos?

Incitados, pois por estes seus aplausos, leitor, os escritores novos procuram principalmente ter estilo! [...] E o público aplaude, o público diz bravo, e o público fica pasmado diante dessa Babel de palavras e de sandices. (CHAGAS, 1865 apud FERREIRA, 1966, p.309-311)

Entendemos que os dois lados disputavam à sua maneira o universo restrito de leitores portugueses. Os novos escritores lutavam para conquistar esse público que, em maioria, prestigiava os escritos da plêiade de Castilho.

Pinheiro Chagas considerava que a tarefa da poesia não era a de inquietar o leitor através da inovação, nem de provocar a transformação do seu horizonte literário. Os princípios da crítica de Chagas também eram os de Castilho, que em sua Crítica literária (1865) afirma estar seguindo uma idéia de Madame Staël. Para estes dois críticos também, o código de princípios morais assenta no "consentimento unânime de todo o povo", derivando igualmente o gosto comum pelo qual se avalia através do gosto nacional. Chagas entende, como os outros dois críticos, que o povo era o juiz da literatura. Reafirmando conjuntamente que este decide igualmente sobre a fama e a permanência de uma obra, estando implícito que a poesia tem de ir ao encontro da expectativa do leitor, se quiser ter êxito. Hess (1978) considera que esta interdependência entre o Ultra-romantismo e o seu 
público, ajuda-nos a compreender a estagnação literária em que estava Portugal nessa época, pois nesta simbiose literária os escritores ficaram restritos ao gosto popular, e o público não teve acesso a novas tendências estéticas.

Contudo, Ferreira (1966) acredita que, meses depois, o autor do Poema da Mocidade teria mudado o tom de sua crítica quanto ao poema de Teófilo Braga devido à influência dos textos críticos de Castilho, que foram elogiosos, mas cheios de restrições quanto ao novo estilo usado por Braga em sua obra. Ferreira (1966) defende que Castilho e Chagas ao associarem a clareza literária com o ideal clássico, foram levados a condenar os escritores de Coimbra, considerando-os como nebulosos, retóricos e gongóricos. Será esta oscilação na crítica de Chagas que trará desconfianças a Ferreira (1966). Para este autor, esse crítico personifica o maior opositor declarado das produções dos coimbrões - uma voz contrária que ecoava insistentemente aos quatro cantos de Portugal devido ao seu jornalismo influente. Talvez a falha na crítica de nosso autor estivesse na maneira sarcástica com que, neste segundo momento, ele analisa os mesmos escritos de Teófilo Braga que elogiara:

Escreve um romance, a paixão vai quase arrebatá-lo, a palavra 'amor' vai-lhe a escaldar os lábios [...] Zás! Uma dissertação sobre o amor; está por um triz a sorrir-se, espera lá, uma dissertação sobre a ironia; a alma a fugir-lhe atraída pelo som melancólico de um sino distante da aldeia, segura-a com uma dissertação sobre os sinos [...]. E a nova geração está quase toda por este gosto. (CHAGAS, 1865 apud FERREIRA, 1966, p.303)

Não podemos, no entanto, dizer que Chagas pecou ao criticar o estilo adotado pela nova escola. Fidelino Figueiredo caracterizou nestes termos o estilo coimbrão, a que aludimos: "Fora moda em Coimbra um certo estilo enfático, que adotava as mais insensatas e híbridas expressões, alterava a construção fixa dos verbos, reunia elementos discordantes, estilo que fora com justiça ridicularizado".(FIGUEIREDO,1916,p.135) Devemos esclarecer 
que houve um grande número de intervenções de ambos os lados que criticavam nos adversários a tendência exclusiva para fazer "estilo". Estilo é uma das palavras mais usadas e que mais carece de precisão semântica na querela coimbrã. Para os devotos da geração Ultra-romântica, aqui centrado na figura de Pinheiro Chagas, o estilo deveria ser a "naturalidade na expressão, modos simples de falar e escrever, entendíveis e claros". (FERREIRA,1966,p.98).

Em se tratando dos embates ideológicos, um grupo era apoiado pelo liberalismo tradicional e o outro pelo socialismo utópico. Como bem dizia Pinheiro Chagas (1865), era a "poesia do sentimento", simples, contra a "poesia social", complicada. Numa posição ainda mais clara, Ferreira comprovou que "o minucioso exame dos artigos de crítica que se escreveram entre 1862 e 1865 prova que existiu uma constante tensão entre duas mentalidades que se chocavam. A situação era de resto o reflexo das lutas ideológicas, filosóficas e artísticas com que se inaugurou o Portugal Moderno [...].”(FERREIRA, 1966, p.110). É unanimidade nas histórias literárias o fato desta querela ter sido não só imprescindível por colocar em discussão uma concepção ainda idealista - porém combatente e interventora - da poesia e da atividade do poeta na sociedade portuguesa, mas também de terem sido revelados através dela grandes personalidades intelectuais, que vieram mais tarde integrar a Geração de 70. Simões (s.d) acrescenta à premissa de Ferreira o fato de que nem Castilho, nem Pinheiro Chagas, nem o próprio Camilo - todos que fizeram humor com a filosofia da Visão dos tempos e das Odes modernas - estavam em condições de apreender o significado filosófico dessas obras. O certo é que, se porventura pudessem medi-las por um padrão literário justo, tão pouco encontrariam nelas condições 
de validez ${ }^{35}$. Por seu turno, Mendes (1997) aponta que as duas escolas sentiam-se ligadas ao romantismo com um certo teor de modernismo, privilegiavam, além disso, o perfil instrutivo e cívico, mas divergiam quanto à função da literatura na sociedade.

Os então conservadores entendiam a poesia como literatura do coração, o folhetim como peça retórica, o romance como distração, e a escrita em geral como educativa manifestação de bom gosto e de bons sentimentos. Os contestadores entendiam-na como algo de grave, como pensamento capaz de alterar a consciência e a ação humanas. Neste contexto crispado justificar-se-á o retorno conciliatório a Garrett ${ }^{36}$. (MENDES,1997, p.457)

Outro ponto em destaque e debate nesta querela foi quanto ao programa de leituras e de imitação. Para o grupo de Antero, o modelo seria o dos românticos do Norte, Vitor Hugo e o "germanismo". Do lado de Castilho evocava-se a já trivializada leitura dos Clássicos de Horácio e Virgílio. Enquanto que este grupo desprezava a cultura filosófica das literaturas estrangeiras - o hegelianismo traduzido em má poesia - os seus adversários escarneciam a ignorância declarada acerca do pensamento da época, acompanhada da prática de uma poesia meramente amável.

Não podemos deixar de comentar que o germanismo apresentava mais características francesas do que puramente alemãs. Muitos autores, como Hess (1978), acreditam que esse tema mereceria ser aprofundado, pois ao mesmo tempo em que estes escritores permaneciam sob o jugo da matriz francesa, eles satirizavam e criticavam a presença dela, sem buscarem com isso medidas para manterem uma identidade literária nacional. Hess considera que ambos os lados da querela coimbrã se encontravam nas mesmas

\footnotetext{
${ }^{35}$ Ver Hess, 1978, p.79. Segundo esse estudo, a análise literária da época avaliava o estilo de Antero como "gongórico" e "marinista", qualidades estimadas como negativas, mas muito próprio da maioria da lírica moderna. Contudo, essa particularidade na poesia de Antero e de outros de seu tempo haveria de deparar com resistências. Por exemplo, Camilo Castelo Branco escrevera que nenhum juízo literário utilizou até então a imagem de um "bago de água pequenino" representando o homem, como criara Antero em `História. Outra expressão que viria a ser ridicularizada por muitos era "estola do infinito", estrofe citada no artigo de Germano Meireles e recuperada de forma depreciativa por Pinheiro Chagas.

${ }^{36}$ Ver Mendes (1997, p.457) Para muitos polemistas, Garrett foi considerado como referência, chegando a ponto de ser lançado um programa literário em sua homenagem por Alberto Osório de Vasconcelos, "O Ermitã do Chiado".
} 
circunstâncias, a admiração deles teria degenerado em cópia. E apesar dos inúmeros artigos sobre a maneira afrancesada de Portugal, não houve, por nenhum dos lados, nesse período, um movimento contrário para reverter a situação de dependência cultural, política e literária francesa.

Quanto às participações das duas facções literárias nessa querela, Mendes (1997) e Reis (2001) consideram que as mesmas revelaram-se desiguais em valor, extensão e autoridade. Muitas vezes afetadas pelo tom excessivamente apaixonado, retirando de seus autores a lucidez que a análise dos temas em debate exigiam. Mesmo assim Ferreira (1966), em sua acurada análise, entende que os textos mais importantes são os de Antonio Feliciano de Castilho, Antero de Quental, Teófilo Braga, Pinheiro Chagas, Ramalho Ortigão e o de Germano Meireles. Mendes (1997) acrescenta a esta lista a rica série de cartas de José de Castilho e o inteligente opúsculo, Duas palavras (1866), contra Antero de Quental de Eduardo A. Salgado. Ainda nos estudos dessa autora, ela ressalta que Antero e as Odes modernas foram os principais alvos dos seus opositores. E, além disso, reforça que há importantes considerações feitas pelo grupo marginalizado pós-Questão coimbrã que são merecedoras de uma revisão crítica $^{37}$; já que as histórias literárias dão bastante relevo apenas aos textos dos coimbrões, futuros integrantes da Geração de 70.

Até aqui, vimos que os antecedentes da Questão coimbrã já estabelecem pelo menos duas premissas que serão exaustivamente recuperadas pelas histórias literárias na biografia de Pinheiro Chagas: ser defensor e sucessor direto dos padrões literários impostos por Castilho e zoilo das personalidades mais destacáveis da Escola de Coimbra. Embora naquela época sua figura já tivesse um destaque na imprensa com suas críticas literárias e políticas, a Questão coimbrã será o divisor de águas no sentido da cristalização de Chagas

\footnotetext{
${ }^{37}$ Cf. Mendes, 1997, p.456
} 
como conservador - de espírito institucional, polemista apaixonado e, acima de tudo, crítico intransigente e parcial - junto às histórias literárias dos séculos subseqüentes ao seu. 


\subsubsection{1.}

\section{O pomo da discórdia: A crítica ao Poema da mocidade}

Em meados de outubro de 1865, o estreante poeta e já crítico literário, Manuel Pinheiro Chagas publica uma obra intitulada Poema da mocidade, seguido do Anjo do lar, com uma carta posfácio de Antonio Feliciano de Castilho. A crítica literária de Castilho pelo seu caráter público, pelas referências que este faz a seus adversários e pelas orientações que sugere ao seu pupilo na conquista de uma posição mais justa e adequada aos seus dotes literários - faz eclodir a Questão coimbrã que teve sua prévia em 1862.

De acordo com os fundamentos de Germano Meireles $(1865)^{38}$, recuperados por Ferreira (1966) e Hess (1978) em seus estudos, o Poema da mocidade reúne assim, de modo exemplar, duas correntes literárias dominantes, aquela representada pela lírica sentimental da natureza de Pinheiro Chagas e a neoclássica pela teoria poética de Castilho, para as quais, as Odes modernas de Antero não podiam deixar de constituir um enorme escândalo. Para Hess (1978), Castilho explorou repetidamente o seu valimento junto ao público e amizade com destacados representantes da monarquia constitucional para impor as suas concepções literárias como únicas vigentes. Como também inculcar a pessoa e a obra de um dos seus protegidos através de um empenho maciço a seu favor. Essa tentativa foi empreendida por duas vezes, uma em 1862, a favor D. Jaime de Tomás Ribeiro e agora a favor de Pinheiro Chagas.

Seja como for, o Poema da mocidade de Pinheiro Chagas será lembrado em dois específicos momentos literários. O primeiro e de maior extensão como gatilho da célebre

\footnotetext{
38 Ver Ferreira, 1966, p.342 - Para esse crítico, o teor ideológico do texto de Germano Meireles é um dos mais significativos e lúcidos que surgiram nessa polêmica.
} 
questão, ou quando alguém se referir à vida ou à obra de quaisquer dos grandes vultos da Geração de 70. Dessa forma, é impossível não acreditarmos que as cumplicidades existentes no movimento contrário aos ideais da geração moderna ajudaram no silenciamento de muitos escritores - que em seu tempo foram personalidades admiradas, consagradas e premiadas como Castilho e Pinheiro Chagas ${ }^{39}$. Acrescente-se a isso as idéias de muitos críticos, como Almeida (1947), Souto (s.d) ${ }^{40}$, Ferreira (1966), Buescu (1997) que nos adverte que sem este incidente, o Poema da mocidade há muito teria desaparecido para sempre e seria apenas mencionado nas histórias literárias somente como um sinal de erudição. Almeida chega mesmo a afirmar que

Para o poeta de muito lhe valeu o escândalo criado à volta do poema, porque com a maior audácia rompeu direito à consagração, tentando todos os gêneros literários, do teatro ao romance, do jornalismo à história, que a par da sua intensa e habilidosa carreira política, bem depressa o transformou numa das figuras mais decorativas do país, com o passaporte de gênio que Castilho lhe passara, Pinheiro Chagas começou a sua ascensão vertiginosa, enquanto "os rapazes da Escola de Coimbra" publicavam nas gazetas da província em prosas repletas de idealismo utópico as aspirações progressivas que deviam caracterizar o melhor das suas obras. (ALMEIDA, 1947, p.578)

Já Monteiro (1943), em sua homenagem ao centenário de nascimento de Pinheiro Chagas, considera que o Poema da mocidade foi propriamente o início do romance da vida literária e política de Pinheiro Chagas, o seu fantasma constante e a tragédia da sua morte. "[...] foi o Poema da mocidade, o ponto de partida, por ter servido, por vontade de Castilho, para provocar a discórdia entre os intelectuais andando, talvez, à mistura das ambições políticas de alguns e dos ideais alevantados e nobres que os outros sempre haviam

\footnotetext{
39 Ver Reis, 1993,p.249

${ }^{40}$ Cf. Souto, s.d, p.58. O Poema da mocidade "está longe de representar um grande peso no balanço positivo da sua obra. Pois, muitos de seus trabalhos que se seguiram a este, sobretudo os romances e os dramas, embora vivendo daquela intransigência que o opôs àquela geração ávida de inquietação social e metafísica, [...] se revelaram duma dimensão superior pelo seu estilo vigoroso maleável e original."
} 
defendido.” (MONTEIRO, 1943, p.59) E, por acreditarmos que não só a obra inaugural de Pinheiro Chagas está hoje silenciada, mas todo o seu espólio literário, é que apresentaremos um resumo deste livro. Para tanto, escolhemos aquele feito por Rainer Hess (1978). Inicialmente, parece-nos uma versão "pequeno-burguesa" da tragédia Romeu e Julieta. Onde a rivalidade entre duas famílias inimigas da obra inglesa é substituída pela diferença de classe. Hess (1978) julga que, embora, a obra seja cenicamente bem conduzida e eficaz, perde-se em tiradas e solilóquios de uma desvairada retórica que já então vinha fora de tempo. O crítico alemão comenta que nesta apresentam-se uma revolução e "novas doutrinas que hão de regenerar a humanidade" - mas estas sublimes doutrinas eram as de Rosseau, aquelas que iriam comemorar dentro de pouco tempo, naquela época, seu primeiro centenário. Sendo que dois anos antes Marx publicara o primeiro volume de $O$ Capital. A transcrição é um tanto longa, todavia a capacidade do crítico em se ater aos dados mais relevantes do entrecho justificam-na inteiramente.

O poema, que apresenta certas afinidades estruturais e motívicas com o drama romântico espanhol Don Álvaro o la fuerza del sino (1835), do Duque de Rivas, compõe-se de quatro cantos constituídos por tipos de verso e por formas estróficas e rimáticas sempre variados. [...]O poema narra o amor ardente de Artur - negros caracóis e olhos negros numa face pálida, de nobres feições - por Ema, encantadora donzela, imagem de castidade e de candura angelical. Ela é filha de uma inglesa de caráter nobre, mas fria e severa, e de um general falecido, que tinha uma perna de pau e desbarata a fortuna em especulações, deixando à mulher, como se diz no segundo, apenas Ema, a farda e um barrete de algodão. [...] A tragédia passional tem início no mesmo canto, quando Artur se ausenta por algum tempo, chamado ao leito de morte de seu pai.

Depois da partida inesperada de Artur, a mãe de Ema, que outrora também se casara por uma ambição sórdida, ardilmente tenta persuadi-la a aceitar a corte que lhe é feita por um Conde abastado, justificando-se na idéia de que o amor é passageiro e os homens volúveis. 


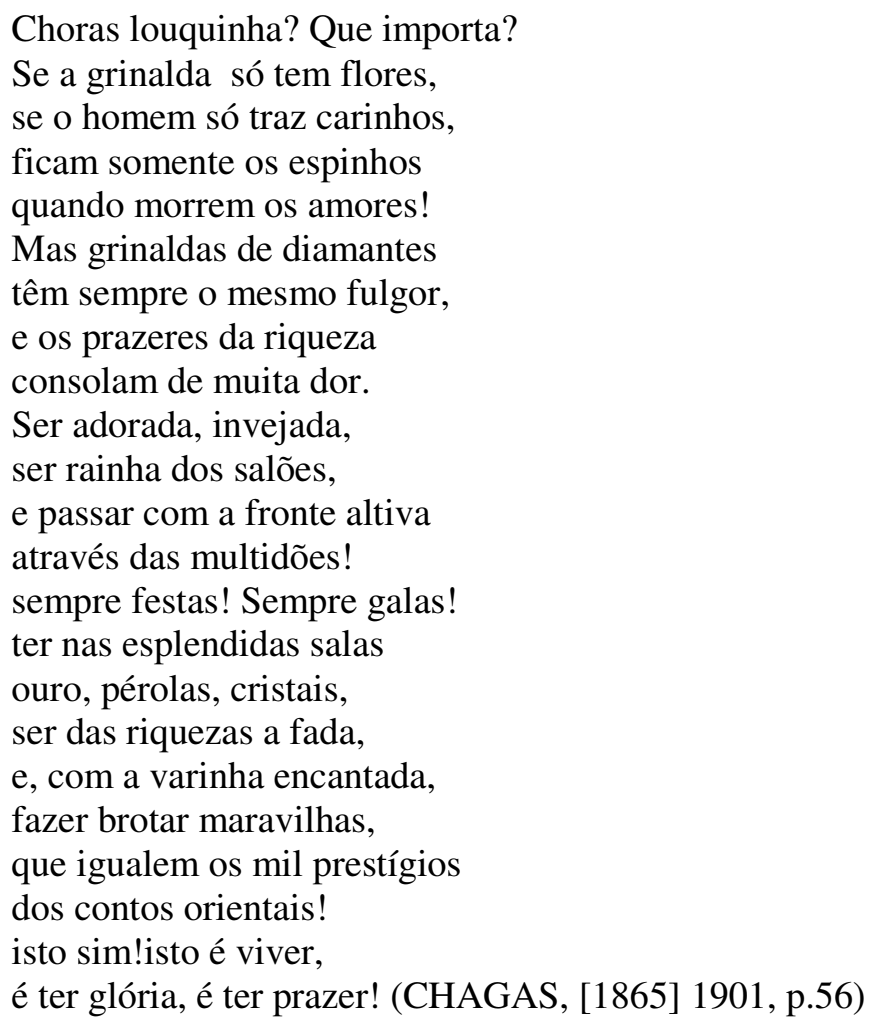

Entendemos, a partir disso, que não se pode inocentar Ema por seus atos, quando esta cedeu diante dos conselhos pérfidos da mãe, porque ela é igualmente motivada pelo egoísmo e ambição.

Em outro ponto da sua análise, Hess apresenta-nos uma característica tão própria do Romantismo, a natureza como espelhamento das emoções das personagens:

Tal como nas horas de amor feliz, a natureza partilha as penas do amor, apresentando-se agora outonal, fria, soturna e triste; nuvens negras obscurecem o sol, as árvores estão despidas, deixou de ser ouvir o rouxinol. Estas imagens da natureza acompanham a ação a partir da separação dos amantes. A estrofe das folhas secas, que caem de leve no chão, surge repetidamente, à laia de motivo condutor. Castilho cita-a como modelar. O infeliz Artur vagueia errante pela província, abatido pela dor e "cismando" - atitude típica do herói romântico - e, num baile esplendoroso, volta a encontrar a amada, acossada por pressentimentos. Os sons da valsa despertam - como é freqüente na poesia romântica - um apetite sensual a que ambos sucumbem, arrebatados pelo reencontro inesperado. $\mathrm{O}$ conde surpreende-os a beijarem-se e, no duelo que se segue, é morto por Artur. Ema retira-se em penitência para um convento, a cujas cercanias desoladas Artur se acolhera, vivendo como eremita, 
sem que soubessem, porém, da presença um do outro. Durante um serviço religioso Artur ouve, por acaso, o nome da piedosa senhora que tão profunda impressão lhe deixara. Um camponês responde à sua pergunta, falando em solenes decassílabos: Ema. Esta notícia faz Artur cair doente e, quando sente a morte avizinhar-se, manda chamar Ema, em busca de amparo espiritual. Ela acorre ao leito do enfermo, em torno do qual se perfilam já o crucifixo, a lâmpada fúnebre e o capelão, reconhece, por entre os planejamentos, o rosto macerado e beija-o, lavada em lágrimas. Artur fala, pela última vez, do seu fiel amor de rosas, do seu puro amor de lírios, depois morre. Na penumbra de um canto, o capelão desfia orações.

Ao final de sua análise, Hess considera que a

conclusão moral indica ser desejo de Pinheiro Chagas que o seu poema seja entendido à luz da sagrada e nobre paixão de Lamartine, que sofreu por Elvira, de Petrarca e Romeu. [...] A juventude é exortada a elevar-se às alturas deste sol, não obstante a aspereza da senda da vida, a suportar sem desânimo a cruz e a ganhar passo a passo o cimo do calvário, sem macular a dor, sem esbanjar a nobreza de coração. Este exagero da moralidade e das paixões e a religiosidade lacrimejante fazem do poema um modelo de lírica sentimental Ultra-romântica [...]. (HESS, 1978, p.82-83)

Nesta passagem, Hess (1978) sintetiza ainda que Chagas com seu poema pretendia, como sugere o seu prefácio, exprimir um duplo protesto: contra o egoísmo e a ambição calculista dos jovens, de um lado fortemente representados por Ema, e de outro, só que em menor intensidade pelo nobre herói, Artur. O autor do Poema da mocidade tinha consciência de que o seu poema sentimental, de feição altamente moralizante, iria necessariamente contrariar a literatura utilitarista da época. Como já explicitamos, Hess (1978, p.81) destaca que “[...] este poema, entendido como uma espécie de cura para os males da civilização, apresenta um elevado grau das características enumeradas por Teófilo Braga na sua definição de Ultra-romantismo." Embora isso, o crítico alemão (1978) encontra também no Poema da mocidade, uma particularidade do Romantismo, o traço do 
“humor romântico". Ela está presente na descrição que Pinheiro Chagas faz das figuras paternas de Ema, característica essa que Castilho reprovou veementemente.

Após a apresentação, embora superficial, da obra de estréia de Chagas, voltaremos agora nossas atenções para a Crítica literária de Castilho por se tratar de um fundamento importante para os desdobramentos da Questão coimbrã. Elegeremos como base de nossas discussões a análise de Hess (1978, p.83-85) por considerá-la mais detalhada e menos parcial nesse sentido.

O primeiro destaque desse crítico se refere ao fato de que, embora Castilho tenha discorrido longamente sobre o Poema da mocidade na sua Crítica literária, é impossível determinar o que Castilho pensava dessa obra. Buscando traçar o caminho da crítica de Castilho, Hess parece desconfiar de um texto que oscila entre o elogio e a crítica, ora acentuando o elogio, ora temperando a crítica de tal forma que quase a retira por completo. Nesse estudo, temos como exemplo da crítica elogiosa de Castilho, a sublime moralidade do poema e certas estrofes bem construídas por Chagas.

Já do lado da censura, Castilho chama a atenção para a impureza formal de alguns versos e a falta de consonância, as quais não dá exemplificações. Contudo, Castilho irá justificar as falhas da obra de Pinheiro Chagas como uma conseqüência da pura falta de tempo do jornalista assoberbado com o seu trabalho. Essa desculpa torna-se perfeita quando Castilho aponta como exemplo a Eneida de Virgílio e as Metamorfoses de Ovídio, que mesmo não sendo obras formalmente esmeradas são modelos literários. A seu ver, o Poema da mocidade de Chagas é tão bom que dispensa comentários - uma clara alfinetada nos “metafísicos” Teófilo Braga e Antero de Quental ${ }^{41}$. Castilho também neste ponto da crítica advoga pelo ordenamento irregular de versos e estrofes, com o intuito de evitar a

\footnotetext{
${ }^{41}$ Cf. Hess, 1978, p.84
} 
monotonia do poema. Dessa forma, ele propunha a criação de unidades rítmicas de extensão variável. Há, no entanto, outra característica da poesia moderna que não se mostra disposto a aceitar com a mesma prontidão, que é a quebra da unidade estilística. Castilho demonstra uma incompreensão fundamental do moderno traço de estilo do humor romântico. Critica ainda a contradição entre o título do canto primeiro - "Idílio" - e os traços estilísticos do humor romântico, de que pelo menos os heróis deveriam escapar por amor à credibilidade das suas paixões. Todavia, essa contradição parece-lhe justificada na caracterização da mãe de Ema que convence a filha a desposar o pretendente mais rico, agindo por motivos baixos torna-se culpada. Castilho abranda, tornando a crítica completamente inofensiva ao asseverar que tais defeitos não passavam de insignificâncias. A apreciação que faz do Poema da mocidade baseia-se no princípio horaciano de desculpar as máculas, quando a maior parte da obra é bem conseguida. Como bem observa Hess (1978), Castilho retira toda a força persuasiva que faz do respeitável princípio horaciano e contamina o seu julgamento pela parcialidade dos seus intuitos de proteção, ao proceder de forma tão sumária e ao postular sem provar a proporção entre defeitos e qualidades, optando por estas.

Pensamos que o fundamento da Crítica literária de Castilho ${ }^{42}$ é essencialmente parcial, se consideramos que este não pretendia abdicar do seu propósito de recomendar Pinheiro Chagas como único candidato à cadeira de Literatura Moderna do Curso Superior

\footnotetext{
${ }^{42}$ Cf. Ferreira, 1966, p.330. Castilho estava a par da campanha de Pinheiro Chagas nos jornais, por isso tenta desfazer as oposições que pudessem surgir contra a nomeação do seu apadrinhado. No dia 11 de outubro, sai no Jornal do Comércio a seguinte nota: "Sabe-se que não tendo os Srs. Mendes Leal, Bulhão Pato e Silva Túlio aceitado o encargo de reger este ano a terceira cadeira do Curso Superior de Letras, fora indicada para esta substituição, enquanto se não provê a cadeira, o nosso colaborador literário Pinheiro Chagas, que já hoje foi apresentado pelo nosso colega Silva Túlio ao Sr. Conselheiro Viale. [...]". No dia 18 do mesmo mês, a Gazeta de Portugal dá nota sobre a nomeação de Pinheiro Chagas para regência interina da cadeira. Concluímos a partir disso que a carta posfácio de Castilho surtiu grande efeito sobre o público e a Universidade.
} 
de Letras de Lisboa $^{43}$. Nesse caso, Castilho não poderia correr o risco da nova escola penetrar pela primeira vez no ensino oficial. Adiantando-se à possível objeção da existência de outros candidatos capazes, como Teófilo Braga ou Antero de Quental, Castilho desqualifica não apenas os dois, mas também um outro possível concorrente, Vieira de Castro, em meia dúzia de frases. A Vieira de Castro dispensa um elogio moderado, mas aponta a sua falta de maturidade e de experiência, enquanto que Teófilo Braga e Antero de Quental são deixados de lado. O trecho que evidenciamos agora é exaustivamente citado nas histórias literárias para ilustrar o descrédito literário que Castilho dispensava aos jovens escritores de Coimbra.

Deixando de parte, por agora, Braga e Quental, de quem, pelas alturas em que voam, confesso, humilde e envergonhado, que muito pouco enxergo, nem atino para onde vão, nem avento o que será deles afinal, por Vieira de Castro digo eu o que o próprio Pinheiro Chagas nunca se lembrou de contestar-lhe: que é um talento verdadeiro, grandioso, exorbitante, e dum futuro que me parece cobiçável. (CASTILHO, [1865] apud CHAGAS, [1865] 1901, p.179)

Em contrapartida, Castilho desenvolve cautelosamente o seu apoio maciço a Pinheiro Chagas. Ele tenta assim ressaltar a superioridade literária do autor do Poema da mocidade, já conhecida pelo público através das suas atuações críticas no jornalismo. Dessa forma, Castilho entendia que a vantagem da nomeação de Pinheiro Chagas ao referido cargo estava no propósito de ser este o mais indicado para curar a literatura moderna que se encontrava enferma. Castilho distinguia dois tipos de literatura atuais, a sã e a enferma, que não passa, na sua essência, de uma paráfrase da máxima de Goethe "Clássico é o são, romântico, o enfermo". E como combate a este tipo de enfermidade literária ele recomenda

\footnotetext{
${ }^{43}$ Cadeira deixada vaga pela doença de Antonio Pedro Lopes de Mendonça.
} 
a leitura dos clássicos, devidamente adaptados à linguagem moderna. Sem perder, com isso, a oportunidade de censurar as tendências neobarrocas da poesia da época ${ }^{44}$.

Contudo, para Hess (1978), a crítica de Castilho é ambígua pelo simples fato de vinte anos antes Camilo Castelo Branco ter ridicularizado a lírica sentimental Ultra-romântica como "poesia gongórica" pelas suas designações barrocas presentes em muitas produções da época ${ }^{45}$. Hess (1978) não concebe a idéia de que Castilho, corifeu literário em seu tempo, não soubesse da crítica exacerbada de Camilo e também não percebesse o traço marinista e gongórico ${ }^{46}$ na poesia do Ultra-romantismo. Dessa forma, ao aplicar a essência barroca só na moderna poesia filosófica e revolucionária, usa de arbitrariedades, pois essa poesia encontra-se em oposição expressa à Ultra-romântica. Hess entende que se Castilho manifestasse de forma mais acurada em seu estudo sobre a poesia social seria fatalmente obrigado a condenar também o Poema da mocidade de Chagas.

Castilho prossegue em sua Crítica literária apontando duas causas que intensificam a enfermidade literária em Portugal. A primeira seria a insociabilidade dos jovens poetas na criação de uma obra ${ }^{47}$ que interferiam na qualidade desta e, por conseguinte, em sua aceitação pública. A última reside na influência nociva de obras estrangeiras ${ }^{48}$, mesmo

\footnotetext{
${ }^{44}$ Ver Hess, 1978, p.84-87. A poesia natural distingue-se pela racionalidade, pelo gosto, pela correção de formas, pela singeleza e pela disposição regular das partes, o uso seguro e comedido dos ornatos. Essa é a poesia que Castilho classifica como sã. Em contraposição a ela, a poesia enferma e artificial apresenta traços de desvario visionário, de nebulosidade metafísica, de descomedimento estilístico, característico de grande parte da lírica moderna.

${ }^{45}$ Ibidem, p.86. Essa postura de Camilo mostra a dificuldade de classificá-lo dentro das correntes literárias do período.

${ }^{46}$ Gongorismo (Espanha) refere-se a uma linguagem metafórica, inversões sintáticas, trocadilhos e alusões. Já o Marinismo (Itália) trata-se de um certo exagero na forma e no conteúdo.

47 Ibidem, p.86-88. Castilho acreditava que o sucesso de uma obra criada na solidão transitória somente seria concretizado depois da apreciação dos escritores já estabelecidos no meio literário. Castilho defendia esta causa mesmo conhecendo as idéias de Madame de Staël que atribuía a originalidade e notoriedade dos escritores alemães ao seu processo de isolamento social e intelectual.

48 Ibidem, p.88-89. Era objetivo de Castilho combater a importância dos livros estrangeiros junto às principais inteligências de Portugal com a valorização de outro tipo de produção literária. Fiel ao seu conceito de classicismo sadio, elege em primeiro lugar a literatura da Antigüidade latina e grega, incluindo posteriormente as literaturas francesa, italiana e alemã. Contudo, acredita que a literatura estrangeira deveria ser lida em traduções exemplares, dispensando os originais. A tradução do Fausto de Goethe é prova disso. Lembrando que depois dessa publicação, surgiu em Portugal a Questão Faustina (1872), uma polêmica literária em torno da versão do Fausto proposta por Castilho. Ao invés de recorrer à obra original de Goethe, Castilho a traduz a partir de outra tradução francesa. Puseram-se em confronto novamente duas
} 
obras de valia. Castilho não cita quaisquer autores ou títulos, limitando-se a referir a leitura ao acaso feita pelos jovens inexperientes e a confusão dos espíritos daí resultante. E na luta contra tais males, o autor de Amor e Melancolia fundamenta suas afirmações invocando autoridades clássicas, Vírgilio, Ovídio, e em maior parte Horácio, de forma literal ou alusiva, mas também autores modernos, como Boileau, Bocage, Chateaubriand e Madame Staël.

Depois de preparar o terreno, Castilho só irá fazer a primeira citação ao nome de Chagas após vinte das sessenta páginas da versão impressa original, e é de novo omitido por cerca de quatro páginas. Ao longo destas, Castilho fala em geral do Curso Superior de Letras e das suas tarefas, para só depois voltar a uma larga apologia ao seu protegido e ao respectivo poema. Esta parte, até o final do texto, é atravessada por digressões estéticoliterárias mais ou menos longas, mas organizadas de tal modo que o nome de Pinheiro Chagas e o seu poema parecem se impor sempre como a melhor ilustração da posição defendida.

Vimos até aqui que a Crítica literária ${ }^{49}$ de Castilho tinha dois propósitos claros. O primeiro de recomendar Pinheiro Chagas como único candidato ao Curso Superior de Letras. E a segunda oportunidade que o posfácio lhe oferecia era ajustar contas com todos os fenômenos literários que não eram de seu agrado, explicando ao público a súmula de sua própria estética. Contudo, para Santos (1991), há marcas de uma leitura tradicional e arbitrária nas histórias literárias quanto às referências que Castilho dispensa a Antero e Teófilo. Esta interpretação gira sempre em torno da ironia agressiva de Castilho aos jovens

gerações, aquela adversária a Castilho, que já estava mais antenada na filologia alemã, logo incapaz de aceitar tal tradução. Intervieram nesta pugna Adolfo Coelho, Antero de Quental, Barreto e Joaquim Vasconcelos de um lado; a favor de Castilho permaneceram José Gomes Monteiro, Camilo Castelo Branco e Pinheiro Chagas.

${ }^{49}$ Autores como Hess (1978) acreditam que este título faz jus ao segundo propósito não declarado de Castilho, mas que este dera tão ampla realização. 
escritores de Coimbra. Santos (1991) com o propósito de desfazer em parte tais impressões negativas, adverte-nos que Castilho já tinha publicamente elogiado as produções dos dois visados: "Porque não admitir alguma sincera perplexidade no autor da Primavera perante uma poesia revolucionariamente inovadora?"50 (SANTOS, 1991, p.39). E este crítico prossegue; demonstrando que na parte final da mesma carta-posfácio, ao defender o emprego de alexandrinos por Pinheiro Chagas, Castilho volta a referir-se a Antero e Teófilo, agora em termos claramente lisonjeiros.

Demos agora parabéns à nossa literatura de haverem afinal triunfado os alexandrinos, ou hexâmetros modernos, os versos ao mesmo tempo mais líricos e mais heróicos de que é susceptível a nossa língua. Eu bem sabia que assim havia de acontecer; por isso teimei.

Deixem-me aplaudir-me a mim próprio da minha constância, a despeito de não sei que lamúrias que ouvi se fizeram em nome do patriotismo contra este metro, só por ser usado dos franceses! Grave pecha na verdade! Esqueceu condenar, com igual fundamento, as dez mil outras coisas boníssimas que da França nos têm vindo.

$\mathrm{O}$ que os alexandrinos valem, o quanto e quão bem se radicaram em pouco tempo, o quanto prometem e já estão dando à nossa poesia, não se vê só nas páginas de Pinheiro Chagas: viu-se em Lobato Pires, vê-se em Mendes Leal, vê-se em Tomás Ribeiro, vê-se em Monteiro Teixeira, vêse em Júlio de Castilho, vê-se em Antero do Quental, vê-se em Teófilo Braga, vê-se em Pereira da Cunha, [...], em vinte outros belos talentos de Portugal e do Brasil. (CASTILHO,1865, apud, CHAGAS, [1865] 1901, p.188)

Também as conclusões de Ferreira (1966), de forma mais tímida, mas não menos importante do que a de Santos (1991), demonstram que a resposta desrespeitosa de Antero

\footnotetext{
${ }^{50}$ Ver Chagas, 1885, $\mathrm{n}^{\circ}$ 50, p.3. Nesse artigo sobre Garret e o seu tempo, Pinheiro Chagas reafirma, de certa forma, as proposições de Santos quanto à Castilho ter se entusiasmado com as obras dos coimbrões, especialmente Teófilo Braga, como exemplificamos a seguir por meio do texto de Chagas: "[...] nunca vi pessoa alguma tão pronta a inflamar-se de entusiasmo pelas estréias brilhantes! Sempre me hei de lembrar de uma visita que ele me fez quando se publicou a Visão dos tempos do Sr. Teófilo Braga. Já a tinha lido, e ele, metendo na algibeira o volume, procurou-me para eu ler e ao mesmo tempo ler para ele para ele ouvir de novo. Depois o Sr. Teófilo Braga irritou-se porque Antonio Feliciano de Castilho mostrou menos simpatia pelas suas teorias do que mostrara pelos seus versos, acusou-o de querer estabelecer em Portugal uma teocracia literária, e de pretender esmagar os espíritos independentes, que não se curvavam a esse jugo. [...]E, apesar de tudo isso, acolheu-o com alvoroço, como ainda acolheu com entusiasmo as Tempestades sonoras, fazendo apenas as suas restrições com relação ao prólogo. E quantas vezes se repetiram a respeito de outros livros o que se dera com este!"
} 
ajudaram a desmerecer aos olhos da posteridade alguns méritos de Castilho. Ambos estudos focalizam a idéia de que:

[...] a hostilidade, tradicionalmente, entre os dois homens terá mais a ver com o condicionalismo em que ambos se encontraram em 1865 do que com radicais e insanáveis divergências pessoais. Muito há de comum entre o Castilho de 1840-50 e o Antero de 1860, mas no ano crucial da polêmica do Bom senso e bom gosto, a questão entre o velho poeta e o poeta jovem ganhou proporções que ultrapassaram em muito a dimensão humana e literária dos adversários. (SANTOS,1991,p.40)

Santos (1991) sugere que as citações sobre os coimbrões feitas no texto de Castilho não justificariam nem o conteúdo nem o tom da resposta de Antero. Explicita que o próprio Antero terá reconhecido, tempos depois, a forma dura com que respondeu ao seu antigo mentor.

[...] 'No meio das caóticas leituras a que então me entregava, devorando com igual verocidade romances e livros de ciências naturais, poetas e publicistas e até teólogos [...]; são significativas a semelhança dos diagnósticos e a repetição da metáfora [...]'.Não custa admitir que algum remorso terá ditado a frase: 'Houve em tudo isto muita irreverência e muito excesso' da carta autobiográfica de 1887 a Wilhelm Storck'. [...]. (IBIDEM, p.38-41)

Apesar destas observações pertinentes, as histórias literárias parecem ignorar esta possibilidade, na medida em que remontam o trecho elogioso de Castilho aos jovens estreantes na representação de suas artimanhas em conseguir aquilo que pretendia.

Contudo, vimos que não só foi maculada a imagem de Castilho devido aos seus embates com os dissidentes de Coimbra, mas também a de Pinheiro Chagas. Bem, de agora em diante será inevitável não se referir a Chagas sem falar da Questão coimbrã, ou viceversa. Essa simbiose às avessas favoreceu expressivamente ao ostracismo de nosso autor. E particularmente, depois desta querela, a Crítica literária de Pinheiro Chagas será considerada nas histórias literárias como conservadora, pouco confiável, medíocre e 
parcial. Analisando rigorosamente o quadro polêmico da Questão coimbrã diríamos sem sombra de dúvidas que Castilho iniciou uma contenda, mas que tinha como protagonista de fato, Pinheiro Chagas. Pensando nisso, agora, gostaríamos de estabelecer um confronto com os dois excluídos do cânone português, Castilho e Chagas. Veremos, então, que ainda assim o autor do Poema da mocidade está numa posição muito mais desfavorável. Por exemplo, o que se abstrai da leitura final da obra de Ferreira é um tipo de absolvição de Castilho mesmo sendo ele, inquestionavelmente, o "chefe da cruzada anticoimbrã". Ferreira chega mesmo, nem que seja de forma sutil, a recomendar uma revisão crítica sobre o autor do Método português.

Castilho reflete [...] uma das suas preocupações fundamentais, e que o acompanharam ao longo de toda a sua vida: o combate por uma escola primária à escala nacional, mas uma escola saudável em que a personalidade da criança fosse respeitada. Esta sua luta, embora sem grande futuro, deveria merecer mais atenção dos historiadores da literatura do que aquela que até agora se lhe dispensou. Castilho teve a infelicidade de, pelos exageros ridículos em que caía, levantar contra si a má vontade das gerações que se lhe seguiram, sepultando no esquecimento tudo o que de mais importante foi de sua lavra. (FERREIRA, 1966, p.320)

Já Pinheiro Chagas não terá a mesma complacência por parte de Ferreira (1966). Para este, Chagas ao desencadear uma "cruzada tão desgraçada e mesquinha" contra Antero e Teófilo Braga - por meio de sua crítica aparentemente ingênua, mas ardilosa e debochada visava tão somente a sua ascensão no meio literário e político. Tanto assim, que Ferreira exaltadamente conclui:

Será necessário aguardar preguiçosamente o ano de 1880 para assistir à autópsia crítica dos sentimentos e psitacismos que norteavam a patriotice de Chagas. Será necessário esperar pachorrentamente pela gargalhada de Eça, assistir, enfim, de alma lavada, à escalpelização crítica do patriotismo dos "brigadeiros vestidos à moderna". (FERREIRA, 1966, p.106, grifo do autor) 
Para nós, Chagas é duplamente odiado e condenado, primeiramente por suas investidas a favor de Castilho e, de outro lado, por não ter sido mais uma voz a intensificar o coro dos dissidentes da nova geração, já que cronologicamente desta fazia parte. Para muitos, contemporâneos seus ou não, a imagem que sobrevive do polemista apaixonado e do crítico profícuo foi aquela dita por Fonseca (1865) quando da Questão coimbrã. Ressaltamos que essa fala nos parece, de forma semântica, fielmente recuperada pelas histórias literárias posteriores ao seu tempo. Para Fonseca (1865), Pinheiro Chagas devotou toda a sua capacidade "ao gênio fatal da sátira, ao demônio do gracejo, para se rir de tudo declara que nada entende, e diz com modéstia humílima, indigna de si, que as Odes de Antero são esfinges”.(FONSECA, 1865 apud FERREIRA, 1966, p.359). Ironia ou não, Chagas será vítima de um projeto caricatural de Eça de Queirós que irá resgatar muitos desses retratos que seus contemporâneos construíram do autor do Poema da mocidade durante os seus embates ideológicos contra os dissidentes da Geração de 70. 


\subsection{2.}

\section{Comuna de Paris: parâmetro ideológico para As Conferências do Cassino}

Seis anos após essa querela ocorrida em Portugal, aconteceria em França um fato histórico que daria novo fôlego aos ideais revolucionários já presentes no meio literário português. Estamos nos referindo à Comuna de Paris que exerceu uma importância crucial nas Conferências do Cassino, realizadas em Portugal.

Como já acenamos, esse movimento, que durou apenas setenta e dois dias, é muito significativo para a história mundial. A Comuna de Paris, para Fontana (2001), é um marco na história das massas populares, sendo, portanto, a primeira vez que trabalhadores conseguiram derrubar o velho Estado, promovendo a partir disso a transformação da sociedade. Sem planos, sem liderança ou organização, as massas demonstraram um elevado grau de coragem combativa, iniciativa revolucionária e criatividade institucional e administrativa. Além da reflexão desse historiador, Boito Júnior (2001) complementa que a Comuna foi o espelho de muitos movimentos trabalhistas e revoluções posteriores que ajudaram mudar a história dos séculos seguintes. Esses dois estudiosos reconhecem que vários teriam sido os fatores que desencadearam a Comuna, sendo alguns desses: a riqueza extraordinária das tradições revolucionárias francesas; a ascensão do movimento operário sob o segundo império napoleônico e a tremenda derrota e capitulação do exército francês de Napoleão III frente à Prússia.

No entanto, uma das questões que ainda gera controvérsias no meio acadêmico se refere à política que a Comuna teria implementado. As suposições estariam entre ser uma política de teor republicano burguesa ou simplesmente uma política de reformas sociais e, 
talvez, uma política socialista. Marx afirmou, em sua obra Guerra Civil na França, finalizada no calor da hora, que a Comuna foi a primeira experiência de um governo operário, mas não disse que ela foi um governo socialista. Os Communards lutaram pela república social e tomaram diversas medidas de proteção ao trabalho e à população pobre. Contudo, para Marx (1975), uma só medida prenunciava ser do tipo socialista, o decreto de que toda fábrica abandonada pelo proprietário - fenômeno comum em tempo de revolução - ficaria sob o controle dos seus operários ${ }^{51}$. Marx ressalta que não se pode perder de vista um fato elementar, o objetivo imediato da Comuna foi depor um governo considerado de traição nacional. Por temor ao proletariado de Paris, o governo napoleônico aceitou uma paz forçada com a Prússia, paz que restringia a soberania da França e mutilava o seu território. A Comuna tinha então pela frente uma tarefa nacional e democrática, que é tarefa típica das revoluções burguesas. Além disso, outras tarefas burguesas contidas como promessa na revolução de 1789 não tinham sido cumpridas; essas consistiam na separação da Igreja e do Estado e a implantação do ensino público, gratuito, obrigatório e laico. Em síntese, a Comuna tinha que levar adiante as transformações burguesas inacabadas para uma futura sociedade socialista.

Já em Portugal, Pinheiro Chagas, algum tempo depois dos acontecimentos da Comuna, faz uma análise crítica da História da revolução da comuna de Paris ${ }^{52}$. Contudo, cauteloso, Chagas (s.d [1872], p.304) classifica seu livro como "uma coleção de documentos" e ainda, pelo pouco tempo decorrido, como uma história em aberto. Quanto à

\footnotetext{
${ }^{51}$ Esta ambígua interpretação, para muitos estudiosos do século XIX, vinha da premissa marxista, segundo a qual "a comuna trazia em si o socialismo". Contudo, essa expressão dever ser entendida como "a comuna tendia ao socialismo". O fato de ter sido ou não a Comuna um governo socialista, ainda hoje, gera polêmicas, pesquisas e novas interpretações.

52 Essa obra se divide em dois volumes, o primeiro dispõe os fatos da Comuna de forma argumentativa. Já o segundo apresenta uma biografia rápida dos líderes da Comuna e suas audiências de julgamentos. Há também no início do segundo volume uma relação dos monumentos e prédios públicos que foram demolidos ou depredados pelos Communards.
} 
apresentação do tema nesta obra, percebe-se uma alternância entre discussão analítica, trechos jornalísticos e teoria socialista, em vez dele apresentar o seu ponto de vista diretamente. Este distanciamento é muito favorável, pois lhe permite demonstrar de forma mais imparcial a constante contradição da parte liberal do programa de governo da Comuna. A organização das citações e sua disposição na narrativa, demonstra-nos o ato metódico do historiador que pesquisou minuciosamente a fonte, buscando reunir dados históricos de um tempo tão próximo ao seu. Ainda quanto à composição dessa obra, Chagas preocupa-se em dialogar com os grandes teóricos políticos do momento, como $\operatorname{Marx}^{53}$. Diferentemente deste, Chagas entende que estava presente na política da Comuna o componente socialista, já que o tipo de democracia que a Comuna estabeleceu era a socialização do poder político, como a eleição para cargos públicos, transferência de tarefas estatais para a população trabalhadora organizada, dissolução do exército permanente e criação de uma milícia operária e, por fỉm, a equiparação salarial entre funcionários públicos e operários.

Depois dessa nossa rápida impressão da obra de Chagas, passemos agora às suas considerações com vistas a identificarmos mais claramente a sua concepção sobre a Comuna de Paris. Conforme se perceberá em nossas escolhas textuais, não faremos uma descrição exaustiva desta obra.

Chagas sem muitos rodeios já no capítulo inicial discute sobre o socialismo na Comuna de Paris e o seu princípio autoritário. Sendo necessário esclarecer que este tema permeará toda a discussão da obra, não seria forçoso de nossa parte dizer que Chagas

\footnotetext{
${ }^{53}$ Ver Chagas, s.d [1872], p.121. Para conceituar o que era verdadeiramente a Comuna e o seu sistema político, pois havia divergências quanto a estas definições até entre os Communards, Chagas traz à luz as idéias de Marx: "A multiplicidade das interpretações a que a Comuna deu lugar, e a multiplicidade de interesses a que a encaravam com favor, provaram que é uma forma política absolutamente expansiva, enquanto as antigas formas eram essencialmente repressivas. Eis o seu verdadeiro segredo: Era acima de tudo um governo de classe operária”.
} 
insistentemente tenta demonstrar, a cada passo do seu discurso, o radicalismo socialista presente no movimento revolucionário em Paris $^{54}$. Contudo, antes de passarmos a exposição de alguns trechos de sua obra, devemos abordar primeiramente por quais princípios políticos este autor se orientava.

[...] para nós o ideal político de todos os homens liberais ${ }^{55}$ está ainda na aplicação sincera dos princípios de 89 com todas as suas consequiências, da mesma forma que o ideal religioso de todos os espíritos pensadores existiu no tempo da Reforma, existe ainda hoje nas páginas sublimes do Evangelho em toda a sua primitiva pureza.

A liberdade em toda a sua extensão, e em todas as suas ramificações, consideramo-la ainda como a palavra definitiva do enigma social. [...] remédio seguro de todos os males que corroem as nações. Entendemos que a civilização e o progresso devem caminhar no sentido do individualismo, que a ação do Estado se deve sentir cada vez menos, que o ideal das sociedades enfim será a ausência completa de governo, sem que a desaparição da entidade administrativa anule as sociedades, ou ponha em risco os direitos individuais. [...] é indispensável que o direito de propriedade lhe seja garantido de um modo inviolável. Todos os sistemas, que não dêem ao homem a posse exclusiva dos bens que ele tiver conquistado legitimamente com o seu trabalho, exigem $o$ estabelecimento de uma tirania insuportável, que obriguem os laboriosos a repartirem, com os vadios, os devassos e os ineptos, o fruto das suas fadigas. [...] (CHAGAS, s.d [1872], p.9, grifo nosso)

Neste fragmento, Chagas deixa claro a sua doutrina política, o liberalismo clássico da Revolução Francesa de 1789 regidos pelos princípios de Igualdade, Liberdade e Fraternidade. A filosofia liberal, como nos fala Chagas, sustenta-se no princípio

\footnotetext{
${ }^{54}$ Ibidem, p. 145

${ }^{55}$ Ver Azevedo, 1999, p.278. Liberalismo é a doutrina que defende a liberdade individual no campo econômico e político. A formulação dos princípios liberais na economia teve em Adam Smith, a sua principal figura, por muitos considerado como o fundador da ciência econômica. Para Adam Smith, o homem é sempre impulsionado por um interesse pessoal, egoísta, sequer pensando na sociedade. Essa preocupação consigo próprio, afirma, conduz o indivíduo, de modo natural, a preferir a modalidade de investimento capaz de beneficiar a sociedade, pois o que é vantajoso para ela também o será para ele, que dela faz parte. Estabelece-se, dessa maneira, uma identificação entre o interesse pessoal e o da sociedade. Assim, "ao perseguir seu próprio interesse, o homem serve muito mais eficazmente ao interesse social do que se tivesse realmente o propósito de lhe servir." Existe, portanto, uma "ordem natural" que se estabelece espontaneamente no domínio econômico. Cabe ao indivíduo descobrir as leis econômicas que, como as leis físicas, conduzem ao equilíbrio da economia. Interesses sociais e individuais se harmonizam, cabendo ao homem o papel de agente econômico ao qual deve ser concedida ampla liberdade de ação. A livre-concorrência não deverá ser objeto de intervenção do Estado ou de grupos particulares. O liberalismo aplica-se, também, à política; neste setor o inglês Jonh Locke surge como o mais resoluto formulador dos princípios liberais, visando dar limites aos poderes do Estado em relação às liberdades individuais. Também na França, com a Revolução Francesa de 1789, o liberalismo obteve novas oportunidades, graças ao triunfo da burguesia e ao aniquilamento dos privilégios aristocráticos.
} 
fundamental de que a liberdade ${ }^{56}$ do indivíduo é o bem supremo na relação do homem com o Estado. Assim, o Estado ideal seria aquele que deixa as pessoas mais livres. Dessa forma, em que medidas a Comuna foi especificamente socialista na concepção de Chagas? Podemos citar dentre as várias "medidas sociais" da Comuna, enumeradas por este autor, pelo menos duas delas que transgrediram os princípios liberais, o direito à liberdade e a propriedade.

O primeiro exemplo concerne na supressão do trabalho noturno dos operários padeiros. Nesta questão, a Comuna teve de tomar partido entre o patronato artesanal de panificação e o operário padeiro, sendo favorável a este último, mesmo apesar dos protestos e manifestações dos patrões. A máxima de Chagas estava na seguinte explicação, se a liberdade de um (padeiro) estava interferindo na do outro (patrão), e estando em posições trocadas essa interferência continuasse, o princípio de liberdade então não existiria. Logo, esse movimento não era regido por idéias liberais, pois a própria coerência do liberalismo exigia a igualdade de oportunidades entre os indivíduos. Devemos esclarecer que todas as medidas econômicas e sociais da Comuna mostravam um caráter operário e popular.

Uma outra lei curiosa promulgada pela Comuna foi a que proibiu aos padeiros o trabalho noturno. Houve as mais sentimentais discussões no seio da assembléia, lamentando diversos membros que existisse uma classe de homens condenados a não verem o dia, a trabalhar enquanto os outros dormem, unicamente para fornecerem de pão mole a aristocratie $d u$ ventre, como dizia na sua linguagem pitoresca o cidadão Vermorel [um dos líderes da Comuna]. Este decreto deu, porém um resultado extravagante, segundo assevera à Comuna, na sessão de 28 de abril. [...]. De forma que eram os próprios operários que protestavam contra a paternal proteção da Comuna! A isso objetava Franckel [outro líder da Comuna favorável a esta lei] que era necessário esclarecê-los, que era 'necessário fazer perceber o benefício dessa reforma que operais. É necessário explicar o motivo porque fazeis essa troca do trabalho de

\footnotetext{
${ }^{56}$ Para os liberais, a liberdade tem total preponderância sobre qualquer outro princípio que possa ser imaginado.
} 
noite em trabalho de dia; é necessário que digais os motivos porque a classe dos padeiros é a mais desgraçada das classes proletárias'. (CHAGAS, s.d [1872], p.194, grifo do autor)

Quando o decreto não agradava a opinião pública, fatalmente ele era revogado em pouco tempo. Para Chagas, houve no período da Comuna uma imensa quantidade de leis propostas, votadas e invalidadas devido ao pouco estudo, reflexão e falta de consenso entre os Communards. Um fato ilustrativo dessa divergência de opiniões estaria na criação de um decreto de lei, depois das abstenções numerosas ocorridas nas eleições suplementares.

A maioria [dos Communards], porém, percebendo que esta abstenção era uma derrota para da Comuna, entendeu que devia recorrer a uma arbitrariedade inqualificável, desprezando a base, que ela mesma fixara. [quer dizer, ir contra a filosofia liberal que se diziam defensores, ao revogar a antiga lei, criando outra para atender aos seus interesses particulares] A comissão, que devia julgar a validade das eleições, propôs que fossem considerados como membros da Comuna os candidatos que tinham obtido a maioria relativa. Isto por tal forma escandaloso, que muitos dos membros da assembléia protestaram. [...] feitas as eleições por este sistema, veio a Comuna declarar que a lei de 1849 estava revogada, que não havia mínimo de eleitores, e que, se entrassem três votos na urna, quem tivesse dois votos era representante de Paris. Isto era simplesmente uma burla indigna, uma arbitrariedade sem nome, o desprezo mais completo pela opinião pública, a conspurcação dos princípios liberais, o ludíbrio do sufrágio universal. (CHAGAS,s.d [1872], p.203-204)

E outros projetos de lei - como a proibição dos patrões de multarem seus operários por quaisquer faltas; o perdão de aluguéis atrasados e o direito irrestrito do trabalhador ao crédito, dentre outros da extensa lista divulgada na obra de Chagas - confirmavam mais uma vez o caráter antiliberal do sistema político da Comuna.

Efetivamente, como se vê, não há doutrina menos liberal 'pedir qualquer cidadão a outro dinheiro emprestado, e combinar livremente com ele o meio de lho pagar, é um verdadeiro insulto à liberdade'. A Comuna não podia aceitar semelhantes idéias. [...]. Intervir o Estado em negócios de interesse particular é sempre um abuso, é uma tirania, e, se esses 
negócios se referem a operações de crédito, essa intervenção não faz senão atemorizar os capitais, introduzir uma grande perturbação no mercado. Não pode haver enfim mais contrário aos princípios liberais de economia política e de organização social do que estas arbitrariedades. (CHAGAS, s.d [1872], p.191-192)

Todas essas citações nos levam a crer que Chagas queria desacreditar, junto ao público, a filosofia política desta revolução, que se mostrava tão alheia e insensível quanto à liberdade individual e à propriedade resguardada. Desse modo, Chagas entendia que a política da Comuna preconizava a máxima jesuítica de que os fins justificavam os meios. Em certo ponto de sua narrativa, Chagas de forma lacônica expõe todas as arbitrariedades cometidas pela Comuna, através de um Estado anárquico complicado com atos de despotismo. Para ele, este governo não hesitava em condenar:

[...] a liberdade de consciência interpretada de modo que dava em resultado a prisão dos padres, o encerramento das igrejas, e a profanação dos conventos; a liberdade de imprensa traduzindo-se na supressão de vinte e sete jornais; a liberdade individual à mercê da prisão arbitrária; a propriedade à mercê das requisições, a indústria regulamentada ditatorialmente; o pobre privado dos recursos do crédito módico; as liberdades municipais violadas pelos que se diziam seus defensores, e que avocavam a si a nomeação dos maires que deviam ser eleitos, revogados por aqueles que diziam não terem recebido mandato senão para fazerem reformas sociais; as ignóbeis discórdias entre os membros da Comuna, que se fulminavam com as mais vis acusações; os generais prendendo-se reciprocamente; os redatores do Jornal Oficial expulsandose uns aos outros, a murro seco, da imprensa, [...] a imoralidade manifestando-se com mais impudência do que no tempo do império; as amazonas da Comuna apresentando a Paris o ignóbil espetáculo de batalhões de viragos sanguinárias, que passeavam pela capital a sua impudência ou a sua loucura; a vergonha subserviência dos membros do governo parisiense para com a Prússia; a ausência completa de sentimentos nacionais. (CHAGAS, s.d [1872], p.199-200)

O texto de Chagas pressupõe não só críticas e reprovações quantos aos princípios socialistas dessa luta, mas também indignação no que concerne aos atos de "vandalismo" executados pela Comuna. Nesse mesmo período na França, a maioria dos intelectuais, 
escritores e artistas, excetuando Courbet $^{57}$, Verlaine, Rimbaud e até certo ponto Vitor Hugo, reagiu com ódio profundo à Comuna, em parte pelas medidas tomadas pelos Communards que atingiam diretamente a classe artística como a destruição de obras de arte espalhadas pela capital francesa - dentre elas a bela coluna de Vendôme ${ }^{58}$.

Agora, acreditamos ser interessante dar espaço a uma passagem do capítulo Incêndio em Paris, que ilustra bem as recriminações de Chagas a todo aquele que comete atrocidades em nome da liberdade. Neste sentido, ele tanto desaprova a política do governo de Napoleão III quanto o da Comuna.

Não; não culpemos a liberdade de todos os horrores que presenciamos, e vejamos pelo contrário neles um novo incentivo para nos fortalecermos na convicção de que os princípios liberais devem estar invencivelmente arraigados nos nossos corações. Demagogias ou ditaduras são igualmente fatais, mas mancham-se com os mesmos crimes, arrojam-se aos mesmos excessos, cometem as mesmas vilanias, e praticam as mesmas atrocidades. O despotismo, debaixo de todas as suas formas, é ímpio, suspeitoso, e inimigo do progresso e da civilização. O segundo império e a comuna profanaram igualmente Paris, aquele com um estigma de lodo, esta com um estigma de sangue. Ambos os poderes nefastos suprimiram todas as liberdades, a liberdade de pensamento, liberdade de consciência, e a liberdade de palavra. É porque a liberdade é luz, e o despotismo só se compraz na treva.(CHAGAS, s.d. [1871], p.34).

Dois pontos foram cruciais para Chagas manter-se contrário à luta dos Communards, um no que se refere à liberdade como vimos nesse texto acima e outro na descentralização do poder. Talvez esse último simbolizasse o maior temor de Chagas, pois o atingia

\footnotetext{
${ }^{57}$ Cf. Chagas, s.d [1872], p.243-244. A demolição da Coluna de Vendôme fora uma das preocupações de Courbet, que era um grande artista, mas que, segundo várias testemunhas, tinha duas idéias fixas, uma a destruição de Vendôme e a outra a Federação dos Artistas. Courbet perante o Conselho de Guerra justificara que a Coluna obstruía a praça, e que era uma feia reprodução da Coluna Trajana: "Eu não queria a demolição da Coluna Vendôme; queria que fosse transferida para a esplanada dos inválidos, por não lhe ser favorável o sítio em que estava. Além disso, a expressão que me servi naquela ocasião foi remover e não demolir." Chagas acreditava que Courbet, orgulhosamente, devido ao elogio de Proudhon que entendera uma vez que um quadro seu tinha uma significação socialista, já se julgava êmulo do grande pensador, e imaginava sinceramente que suas Baigneuses pesavam tanto na balança dos destinos da humanidade.

${ }^{58}$ Ver Chagas, s.d [1871], p.23-28. Foram ordenadas pela Comuna três demolições importantes: a da Igreja Bréa, da Capela Expiatória de Luiz XVI e da Coluna Vendôme. As duas primeiras não foram executadas. Já a terceira, infelizmente, foi demolida por mãos francesas em 18.05.1871.
} 
diretamente como parlamentar, caso Portugal viesse a aderir também ao movimento revolucionário popular. Por outro lado, não podemos também nos esquecer de outra não menos importante preocupação de Chagas que constitui a perda da liberdade de imprensa. Chagas, como jornalista político e folhetinista, acreditava que a supressão desse direito ocasionado por uma possível revolução igual a da Comuna, poderia de certa forma interromper a modernidade pela qual passava o jornalismo português ${ }^{59}$. Dessa maneira, ele buscava de forma abrangente e sagaz argumentar sobre a liberdade como um princípio básico de todo homem, para com isso ganhar a simpatia popular, deslocando o foco daquilo que seria realmente uma ameaça, não à nação, mas especificamente à classe de imprensa e política em Portugal.

Não demorou muito para que houvesse, no meio literário português, vozes contrárias a esta analogia feita por Chagas entre as idéias revolucionárias da Comuna e os ideais da intelectualidade em Portugal. Uma dessas reprovações veio de Sampaio Bruno na sua obra Os modernos publicistas portugueses. Nesta, seu autor (1906) assinala a postura conservadora, falsamente liberal e retrógrada de Pinheiro Chagas acerca do estudo sobre a Comuna de Paris. Bruno censura não só o imediatismo de publicação, mas também a má elaboração do texto que expõe uma retórica militarista enfática, não conseguindo ocultar o chauvinismo do seu autor.

Mais adiante na sua análise crítica, Bruno assinala que a imprensa dita como liberal, aqui prefigura Pinheiro Chagas, não consegue analisar e nem compreender o movimento da Comuna de Paris. E conclui, que este tipo de jornalismo limitava-se também a fazer um

\footnotetext{
${ }^{59}$ Ver Venâncio, 1998, p.213. Segundo esse estudo, Teixeira de Vasconcelos, jornalista de profissão, considerava que “os escritores que são hoje o ornamento das letras nacionais, todos receberam o batismo na pia jornalística e foram os gloriosos ascendentes da novíssima geração dos redatores portugueses". Sem falar que esses jornais contribuíam diariamente para a divulgação da leitura, educando e divertindo o público. Outro ponto destacado no texto de Vasconcelos é o fato de que, para muitos, a língua portuguesa perderia sua vernaculidade através dos textos jornalísticos. No entanto, esse autor acredita que o periódico possibilitou um maior contato da língua portuguesa com o público.
} 
estudo superficial sobre o teor socialista no projeto Ibérico em Portugal e nas Conferências

do Cassino.

Verdadeiramente, o que nos interessa agora é conhecer em que sentido as preocupações do autor do Poema da mocidade relacionadas aos fundamentos políticos da Comuna, como o socialismo ${ }^{60}$, teriam uma ligação intrínseca com dois projetos políticos em Portugal - a realização das Conferências do Cassino e, outro mais utópico, o projeto da República Ibérica $^{61}$ - já que Chagas cita este último no primeiro capítulo da História da revolução da comuna de Paris.

Conhecidos os princípios da associação operária acerca das nacionalidades $^{62}$, bem se pode supor que entre nós a propaganda internacionalista se liga intimamente com a propaganda Ibérica. Todos aqueles efetivamente, que em Portugal têm procurado difundir o pensamento socialista, igualmente procuram apagar no fundo das almas portuguesas esta idéia sagrada de pátria. Nem podia deixar de ser assim. A frase pomposa ' $O$ trabalho não tem fronteiras' arrasta consigo essas inevitáveis conseqüências. (CHAGAS, s.d [1872], p.20)

O projeto Ibérico defendido em Portugal tinha como representantes os primeiros socialistas portugueses, dentre eles Antero de Quental. Dessa maneira, não foi difícil

\footnotetext{
${ }^{60}$ Cf. Azevedo, 1999, p.419-420. Socialismo, também definido como reação ao liberalismo capitalista, critica a injustiça social inerente a este sistema, propondo-se substituí-lo por uma sociedade sem classes. Não obstante a grande variedade de sistema socialistas propostos ao longo do tempo, é inegável que a publicação do Manifesto Comunista de Karl Marx e Friedrich Engels, em 1848, deu uma nova dimensão ao socialismo. No socialismo há: o predomínio do bem comum em detrimento do individual; planificação da economia; eliminação das classes sociais e manutenção de certa modalidade de propriedade. O socialismo tem sido analisado sob diferentes nomes e concepções: o utópico que valoriza o indivíduo numa sociedade ideal, protetora e condenando o lucro; o científico, resultante de enfoque e teorias marxistas e, por fim, o cristão, também rotulado de catolicismo social sem, no entanto, advogar o igualitarismo.

${ }^{61}$ Voltaremos à questão da União Ibérica no Capítulo III, no qual discutiremos a crítica de Pinheiro Chagas.

${ }^{62}$ Cf. Chagas, s.d [1872], p.14-20. A associação internacional tinha como finalidade estabelecer solidariedade aos operários de todo o mundo, para se emanciparem do jugo do capital. Seu programa consistia em organizar uma sociedade universal, com o fim de proteger as exigências dos operários manifestadas nas greves. E diante da coletividade social desapareciam família, associação e pátria. Para Chagas, a Internacional "proscreve o amor da pátria, combate às guerras nacionais, não por serem atentados contra a fraternidade humana, não por serem hecatombes que horrorizam, mas porque os povos devem concentrar todas as suas forças, empenhar todo o seu zelo na guerra social."
} 
Chagas associar que estariam ali presentes os princípios da Comuna ${ }^{63}$ e do socialismo, pois,

para Antero, toda a península estaria sujeita a uma última salvação, a uma

[...] única política possível: a federação republicano-democrática. E, em face desta formidável unidade de interesses, de idéias, de vontades e de aspirações, que podem as barreiras da nacionalidade significar mais do que a tradição, um símbolo poético, cujo sentido perde de dia para dia, até se tornar de todo incompreensível, até desaparecer? [...] Moralmente essas barreiras caíram já. Para as consciências mais retas, para as inteligências mais seguras dos dois povos, unidas nos mesmos desejos e num pensamento comum, a nacionalidade não passa de um obstáculo desgraçado, resto das hostilidades fatais de séculos bárbaros e que só por um lamentável acordo dos interesses da minoria dominante e dos prejuízos da multidão inteligente, se tem podido sustentar. (QUENTAL, s.d [1872], Vol II, p.77-78)

Tempos depois, Antero irá considerar tais investidas como uma "grande ilusão" em épocas de muitos estudos filosóficos e ideais. Nesse Antero dessa fase, são muito pouco visíveis o sentimento de patriotismo e o amor da independência, ou melhor dizendo, não existe em nenhuma medida. Já para Chagas, há dois tipos de patriotismos, um que ajuda a estabelecer a unidade, o progresso e a tradição de qualquer povo e, de outro lado, o patriotismo decorativo e afetado que destrói a nação. Como nos revela parcialmente uma de suas digressões sobre esse tema, recuperada da sua obra da Comuna.

Durante o primeiro cerco de Paris, o inimigo sabe que os demagogos [um tipo de membro da Comuna] são os mais patriotas de todos os Franceses... porque eles assim o declaram lutando contra os seus concidadãos. Amaldiçoam a Prússia, mas dilaceram a França. [...] Assim também condenam a paz que a Assembléia assina, só falam em continuar a luta, levam consigo os canhões, e voltam-nos...contra os Parisienses. O amor da pátria cega-nos, e tanto que deixam os Prussianos ocupar

\footnotetext{
${ }^{63}$ Os princípios de liberdade e descentralização serão o cerne da proposta de governo da Comuna. Contudo, Chagas acreditava que os Communards "[...] incertos, contraditórios, querendo formular um programa político, formulavam apenas um programa violentamente socialista, e quando, em presença da lei descentralizadora de 11 de abril de 1871, votada pela Assembléia de Versailles, quiseram responder com uma exposição de princípios mais radical, e mais descentralizadora, não fizeram senão apresentar o plano de uma federação de grandes cidades, independentes umas das outras, e horrivelmente despóticas na sua administração interna". (Ver Chagas, s.d [1872], p.129) Certamente, depois de um tipo deste de governo estaria em jogo o sentido de nação, o qual sempre foi defendido por Chagas.
} 
tranqüilamente Paris, essa Paris que incendiaram depois, quando as tropas que lhes batiam às portas eram as tropas francesas.

Dizemo-lo bem do fundo da nossa consciência: é esta comédia uma das coisas para nós mais ignóbeis da revolução da Comuna, é esta máscara de patriotismo que põem no rosto os homens, que consideram a idéia da pátria como um preconceito, que se deve pagar em todas as almas, é, sobretudo, o cálculo da guerra civil, seguido friamente através das preocupações aflitivas que pungiam Paris e a França, é enfim essa bandeira vermelha que eles enrolam cuidadosamente no crepe das horas lutuosas, para a desfraldarem sobre Paris que tinham iludido, sobre Paris que os aplaudira, julgando-os, até o momento das primeiras loucuras e dos primeiros crimes, os fiéis defensores dos seus direitos e dos seus foros. (CHAGAS, s.d [1872], p.61-62 grifo nosso)

Dessa forma, o projeto socialista que Chagas combate é também o que ele chama de uma verdadeira conspiração contra a idéia de Pátria. Essa relação baseia-se no sistema de organização política da Comuna fundamentado na fragmentação do território em partes independentes e soberanas. Conforme se percebe, para Chagas, esse tipo de governo faria qualquer país perder a noção de nacionalidade, deixaria de existir todo um povo, uma língua, uma tradição. Temos, talvez, aqui o princípio das divergências sobre a idéia de patriotismo, que seria mais tarde um dos motivos por que Eça de Queirós o irá demolir com esfuziante ironia, classificando-o de "Brigadeiro Chagas".

Novamente, Antero estaria envolvido em outro projeto muito mais revolucionário e ameaçador do que o projeto da república Ibérica, estamos nos referindo às Conferências do Cassino. Chagas, acreditando que as idéias do movimento revolucionário da Comuna refletiam diretamente nas Conferências do Cassino em Portugal, vem apoiar no Jornal da noite de 30.06.1871 a proibição das mesmas. Em quatro de julho, no Diário de notícias, Chagas fala de comunismo atacando os que professavam as idéias que pairavam no Cassino. Antero e Batalha Reis, pedindo explicações, enviam então a Pinheiro Chagas como testemunhas, Eça e Salomão Sarragga, que publicam depois, em 06 de julho, em 
vários jornais da capital, uma carta dando conta dessa missão, dela constando a seguinte declaração de Chagas $^{64}$ :

Declaro que no que escrevi no meu folhetim de segunda-feira, três do corrente, relativo aos precursores do socialismo, não tive intenção de ofender, nem sequer de aludir por forma alguma aos srs. Antero de Quental e Jaime Batalha Reis, nem supus que ainda muito remotamente se lhes pudessem aplicar as frases de que me servi. (CHAGAS, 1871 apud MATOS, 1988, p.712).

As justificativas governamentais quanto ao fechamento das Conferências do Cassino regiam em torno de que haviam sido professadas doutrinas contrárias à religião do Estado e da lei fundamental do reino, assim Martens Ferrão redigira:

Pretender iludir a religião do povo, proscrevendo o seu ensino; lançar à conta da ordem social todos os males públicos, que são nada em vista dos que assim se preparam; recriar o ódio das classes, e a guerra ao capital, que é a luta contra a propriedade, é a feição proeminente de uma escola de anarquia generalizada na Europa, cujos protestos todos os dias estão sendo publicados, e que, quando chegados a pôr em prática, produzem as abjeções do movimento republicano na Espanha, e os horrores da Comuna.(FERRÃO, 1871 apud MATOS, 2001, p.345).

Passado dois meses, Pinheiro Chagas discursava no parlamento, em defesa do governo com os seguintes questionamentos:

Qual era o fim das Conferências Democráticas? Podemos supor que os inteligentíssimos cavalheiros que as iniciaram e dirigiram, e que se afirmam, que se confessam, que se gloriam de se dizer os precursores do socialismo em Portugal, se reuniram apenas por mero acaso, por mera coincidência? (CHAGAS, 1871 apud MATOS, 2001, p.345).

\footnotetext{
${ }^{64}$ Cf. Matos, 2001, p.344. Esse episódio remete-nos a outro da ficção eciana, em Os Maias. É muito similar à descrição quando Cruges e João da Ega vão, como testemunhas, em nome de Carlos da Maia, desafiar o confuso Dâmaso Salcede e arrancar dele um documento de retratação.
} 
Ramalho Ortigão ([1871]1943), ironicamente, em As farpas, não esconde sua surpresa quanto à postura reacionária de Pinheiro Chagas, em seu primeiro discurso como deputado, no apoio ao encerramento das conferências democráticas.

O Sr. Pinheiro Chagas sabe todas estas coisas [a história é testemunha das atrocidades que se cometeram em privar os indivíduos de suas liberdades em favor de uma falsa segurança pública] tão bem como nós, ou antes muito melhor que nós. É um espírito esclarecido e reto. A contradição que assimilamos entre o seu brilhante passado como escritor público e o seu primeiro discurso como deputado manifesta apenas o deplorável caso da influição perniciosa da política portuguesa nas inteligências mais elevadas e mais dignas.(ORTIGÃO; QUEIRÓS, [1871] 1943, p.98)

Para Ortigão, a portaria que mandou fechar as conferências democráticas não foi só uma flagrante violação da lei aplicável àquele caso, como também um atentado claro e terminante contra a liberdade de expressão, sem a qual é nula a liberdade do pensamento. Pinheiro Chagas ao proferir a favor do fechamento das Conferências do Cassino justificado pelas circunstâncias especiais em que se achava a Europa - contradizia as suas concepções de escritor liberal, ficando desacreditado pela crítica e perante o conceito público. Contraditoriamente, Chagas agora legitimava o governo português das mesmas arbitrariedades que um dia reprovou nos atos da Comuna, quanto à supressão da liberdade individual da palavra.

todas as conferências estavam subordinadas a uma mesma intenção; um dos conferentes, [Eça], aplaudia e exaltava o Realismo, especialmente porque o considerava a arte posta ao serviço do socialismo; outro, falando acerca do ensino [Adolfo Coelho], como que via no ateísmo a conclusão lógica de todas as ciências humanas, defendendo assim essas idéias ateístas ou niilistas, que, tanto na escravizada Rússia como na França apaixonada da liberdade, parecem ser o apanágio de todas as escolas socialistas; outro, enfim [Antero] falando da decadência da Península nos últimos três séculos, decadência infelizmente bem evidente, apresentava como único remédio, que podia curar os nossos males, como único obstáculo à nossa decadência, a república socialista. (CHAGAS, 1871 apud MATOS, 2001, p.345). 
Como se apresenta nesse texto, Chagas considerava que a máxima do socialismo permeava todas as conferências, não sendo, portanto, um momento de reflexão dos problemas sociopolíticos da nação portuguesa, mas sim a divulgação da república socialista. À luz da concepção do autor d' A morgadinha Val Flor quanto ao socialismo em Portugal, podemos abstrair que ele o considerava como uma postura política altamente prejudicial e perigosa para a liberdade na nação portuguesa. E para sublinhar melhor o perigo do socialismo ao público português, Chagas (1871 apud MATOS 1988, p.712) vai aproveitar-se do exemplo da Comuna de Paris afirmando, "Nós bem vimos que, quando a Comuna estabeleceu em Paris o seu império despótico, a primeira coisa que fez foi suprimir todas as liberdades que a República de quatro de setembro mantivera entre os horrores e as dificuldades do bloqueio prussiano". Pinheiro Chagas, como historiador e estudioso que era, tinha consigo que Portugal era estreitamente vinculado às revoluções que ocorriam nos outros países da Europa. Já havia acontecido em outros tempos, mesmo depois de um atraso de quase trinta anos, Portugal promovera, a partir de 1820, transformações culturais e políticas devido às influências liberais da Revolução Francesa, em 1789. Podemos citar dentre essas, a queda do sistema monárquico absolutista dando lugar ao liberalismo como doutrina sociopolítica e a ascensão da burguesia. Contudo, nesse específico momento, para Chagas, a influência do estrangeiro seria imediata, pois as idéias socialistas da Comuna poderiam circular livremente, facilmente e rapidamente por Portugal por meio do trem e do telégrafo.

À medida que vamos fazendo recortes na trajetória historiográfica de Pinheiro Chagas como escritor, crítico, político e polemista, veremos as impressões negativas advindas de suas colocações públicas e de seus embates com seus opositores políticos ou literários. Da 
Questão coimbrã ficou nitidamente impressa a figura de crítico medíocre e intransigente. Já das suas investidas como historiador e político nestes desdobramentos da Comuna de Paris, contrário ao socialismo, aos projetos revolucionários da República Ibérica e das Conferências do Cassino, ficaram colados à sua imagem os epítetos de reacionário e conservador.

Curiosamente, suas desaprovações à Comuna estariam presentes no curso de sua vida, e conseqüente morte. Foram os seus comentários depreciativos à anarquista francesa, apelidada de Vierge Rouge, Louise Michel, a razão de um atentado sofrido em 1888 que debilitou, a partir disso, a sua saúde. 


\subsection{3.}

\section{O Realismo: projeto revolucionário nas letras}

Não podemos considerar que os pareceres de Pinheiro Chagas sobre As Conferências do Cassino - principalmente do texto eciano, A nova literatura, o Realismo como nova expressão de $\operatorname{arte}^{65}$ - constituem uma polêmica entre ambos. No entanto, é necessário esse parêntese, se assim podemos considerá-lo, para que se possa clarificar os princípios estéticos da "nova literatura" que suscitarão, juntamente com o patriotismo, discórdias entre o autor de $O$ crime de padre Amaro e o autor da Morgadinha de Val Flor no futuro.

A abertura das conferências foi realizada por Antero de Quental em 22 de maio ${ }^{66}$ com uma palestra intitulada $O$ espírito das Conferências. Trata-se de um movimento revolucionário ideológico, como bem afirma Antero na apresentação dos objetivos principais das Conferências. Os pontos centrais desse texto concentram-se na necessidade de introduzir Portugal no movimento moderno presente em todos os países civilizados sem, contudo, esquecer-se de investigar as condições de mudanças nos campos, social, político e econômico da sociedade portuguesa ${ }^{67}$. Antero, cinco dias depois, em sua segunda conferência intitulada Causas da decadência dos povos peninsulares, atribui essa decadência ao catolicismo e à inquisição, ao absolutismo e às conquistas do Oriente.

\footnotetext{
${ }^{65}$ Ver Berrini, 2000, p.9-22. Não será possível a reprodução fiel das idéias de Eça presentes nesse texto, pois seu original apresentado nas Conferências do Cassino não mais existe. Segundo Berrini, o que é recuperado pelas histórias literárias são fragmentos de alguns artigos com impressões e comentários da conferência de Eça publicados nos jornais da época. Especificamente, essa autora prioriza os textos de Alberto de Queirós, Pinheiro Chagas, Luciano Cordeiro, tendo ainda outros sem assinaturas. Importante salientar que a maior parte da crítica, como a dessa autora, elege a obra de Antonio Salgado Júnior, História das Conferências do Cassino (1871), como a mais completa reconstituição do texto de Eça.

${ }^{66}$ Cf. Campos Matos, 1988, p.173. Quatro dias antes da abertura das Conferências do Cassino, sobre $O$ Espírito das Conferências dirigida por Antero, havia terminado a "semana sangrenta" (12 .05 a 18.05.1871) da Comuna de Paris.

${ }^{67}$ Cf. Simões, 1945, p.285
} 
Eça será o autor da quarta conferência, em 12 de junho, A nova literatura, o Realismo como nova expressão de arte ${ }^{68}$, onde critica o "mundo oficial, constitucional, burguês, doutrinário e grave". Antonio Salgado (1871) ao remontar a conferência eciana estabeleceu que a mesma se fundamentava no espírito revolucionário e que este deveria estar presente em todos os setores da sociedade moderna. Contudo, para ele, o único setor que ainda persistia em não aderir ao movimento revolucionário era a arte, apesar de essa também ser de interesse da revolução. Segundo Salgado, Eça tinha em mente que a aspiração e a obra do espírito revolucionário têm como norteadores três aspectos, sem os quais esta não se completa, o verdadeiro na ciência, o justo na consciência e o belo na arte. Dessa forma, o princípio fundamental era de que a arte não aparece nas sociedades como um fato isolado, mas sim intimamente ligada ao progresso e decadência delas. E, portanto, apresentando-se de acordo com as épocas históricas, como também sofrendo influência destas.

A arte [...] devia considerar-se, [...] ligada a todos os movimentos sociais, determinada, condicionada por causas permanentes e por causas acidentais ou históricas. As causas permanentes são as que residem no solo, no clima, na raça; as acidentais provêm de uma certa ordem de idéias que formam os diversos períodos históricos e determinam os costumes. [...] tanto umas como as outras sujeitavam o artista ao seu despotismo. [...] Por outro lado, o artista não pode eximir-se à influência do meio em que vive, aos costumes do tempo, ao estado dos espíritos, ao movimento geral, às causas acidentais ou históricas. - Eça de Queirós demorou-se aqui a insistir nessa idéia antes que exemplificasse. Insistiu em que a arte obedece fatalmente à mesma lei que determina nas sociedades as grandes evoluções de princípio, de instituições e de costumes. - [...] [a arte] tira da sociedade a sua idéia, a sua forma, os seus intuitos.(SALGADO, 1871 apud MATOS, 1988, p.173, grifo do autor)

Simões (1945) julga que a originalidade da conferência de Eça é a conciliação da teoria determinista de Taine sobre a influência do meio e do momento histórico na criação artística. Tudo isso associado ao princípio moral de Proudhon sobre o papel social do

\footnotetext{
${ }^{68}$ Ver Campos Matos, 1988, p.173. Segundo esse autor, Eça intitula esse mesmo texto em As farpas com outro título, o de $A$ afirmação do Realismo como nova expressão de arte.
} 
artista e sobre a utilidade da arte. Entendemos que Eça sabia que as conferências eram obra de Antero, e este exigia pensamento, não gargalhadas. Para ter escrito As farpas não precisou de doutrinas, bastava-lhe o irônico riso. Então, lembrando-se de Proudhon, decidiu expor pontos de vista que não estivessem em desacordo com o mestre ${ }^{69}$. Dessa maneira, o texto de Eça, como sugere Simões (1945) apropria-se das operações sociais do momento e propõe a restituição da consciência social. Além disso, Hess (1978, p.141) acrescenta que tanto para Eça de Queirós quanto para Antero de Quental “a realidade representada devia ultrapassar-se a si mesma, apontando para a verdade absoluta, e de que a arte deve adequarse às condições sociais". Contudo, ainda sob a vertente desse crítico, Eça teria mais rigor do que Antero em considerar o Realismo literário como reação tanto contra a linguagem da poesia neoclássica e da arte pela $\operatorname{arte}^{70}$, como da exaltação romântica dos sentimentos. Na verdade, para Eça, a falta de unidade associada à resistência ao espírito revolucionário seria, sobretudo, o empecilho para a modernidade das letras portuguesas. Todo o discurso de Eça encontrava-se no silogismo, se o homem tende à revolução e a arte é a consciência do homem, então, a arte seria a revolução. Eça ao traçar o percurso histórico da arte recuperando um pouco os fatos que marcaram a França, no domínio da política, da economia e também no campo artístico - prepara o terreno para atacar a literatura atual em Portugal. Neste momento de sua conferência, ele discute que a arte francesa do segundo império é completamente nula de tradição inovadora. Haveria, portanto, nessa fase, uma apatia revolucionária na política que refletida na literatura tornava a mesma uma verdadeira

\footnotetext{
${ }^{69}$ Cf. Hess, 1978, p. 141. Nessa época, Eça foi acusado de plagiato por não ter feito referência em seu texto da conferência sobre a origem das idéias, que seria Du príncipe de l' art et de sa destination sociale de Proudhon, publicado postumamente em 1865. A crítica mais circunstanciada foi a de Luciano Cordeiro, em dois artigos de jornais, que provou também que a introdução apresentada por Eça da evolução literária em França, desde Revolução até o segundo império, bem como a oposição das telas românticas com as realistas advinham desse livro francês.

${ }^{70}$ A idéia contida na expressão "arte pela arte" remonta a Aristóteles que recusava admitir os propósitos didáticos para o fenômeno estético. Essa teoria teria a arte exclusivamente para proporcionar prazer estético, quer dizer, nela se desconhece fins utilitários com a moral, a política e a educação.
} 
contra-revolução. Eça, de acordo com Salgado, teria apresentado este tipo de literatura como uma falsa literatura em desacordo com o ideal social.

[...] Na decadência que ostenta, encontra-se em perfeita contradição com a sua época. Com efeito, no seu maior desenvolvimento, tudo é imitação. Hugo concebe o gótico e escreve a Notre-Dame ${ }^{71}$, Ponsard adota uma maneira grega, [...]. Dá a impressão de que a sociedade não tem essa idéia-mãe e que, por isso, não pode ter arte própria. E assim, a arte decai no drama, na poesia, na pintura... Dir-se-á que por falta de gosto: - mas o gosto está mais educado que nunca. Também não é por falta de estudo: sabe-se mais do que nunca. Nem por escassez de público, nem por falta de talento. Há todos esses elementos para produzir uma grande arte. (SALGADO, 1871, apud, MATOS, 1988, p.175)

Seguindo a perspectiva da recepção crítica, nas palavras de Simões, o que mais impressionou ao público da época teria sido:

a clareza do diagnóstico indiretamente formulado acerca da enfermidade das nossas letras. $\mathrm{O}$ seu ataque direto à retórica e à sentimentalidade convencional da nossa literatura, salpicado de referências ao Realismo, fez tremer os representantes oficiais das indigestas letras pátrias.(SIMÕES, 1945, p.290).

Em outro momento de sua discussão, este autor adverte-nos que se estaria repetindo o caso da Questão coimbrã. Essa aproximação feita por Simões até certo ponto é coerente. No entanto, não consideramos que aqui estivesse apenas em jogo concepções literárias ligadas às funções da literatura e à posição do escritor na sociedade, mas também às questões estéticas, ideológicas e históricas. Seguindo a lógica de Simões, a nova realidade literária propagada por Eça de Queirós seria uma ameaça direta à literatura que ele, Pinheiro Chagas, representava. Esse aspecto sobre Chagas também será mais tarde

\footnotetext{
${ }^{71}$ Ver Queirós, 1871 apud Berrini, 2000, p.26. Alberto de Queirós na sua transcrição da conferência do irmão não concorda com este quanto à associação de Vitor Hugo a este tipo de literatura, já que o escritor francês escrevera também Os Miseráveis. Alberto de Queirós considera que se esse romance não é realista, constitui uma grande epopéia social.
} 
resgatado nos estudos de Ferreira (1966) sobre a questão do Bom senso e bom gosto, como já discutimos.

Sob esse prisma, torna-se ainda fundamental apresentarmos mais idéias ecianas sobre o Realismo nessa conferência, mesmo que não tenhamos uma reprodução fiel do texto que apresentou. O furor que a sua apresentação causou no meio literário português pode ser comprovado pela quantidade de folhetins produzidos, a favor ou contra, dependendo das concepções literárias de cada escritor ${ }^{72}$. Sem falarmos na preservação dos principais pontos discutidos por Eça em seu debate, presentes nas reproduções, como este que apresentamos a seguir:

[...] A nossa arte é de todos os tempos menos do nosso. [...]O Realismo deve proceder pela experiência, pela fisiologia, ciência dos temperamentos e dos caracteres. O Realismo deve ter o ideal moderno que rege as sociedades, isto é, a justiça e a verdade. A arte não dever ser destinada a causar impressões passageiras, visando simplesmente o prazer dos sentidos. Deve visar a um fim moral: deve corrigir e ensinar. Se a arte não estabelece a moral, - perderá a sociedade. Pelo contrário; [o Realismo] visando esse fim, auxilia o desenvolvimento da idéia de justiça nas sociedades. Fazendo a crítica dos temperamentos e dos costumes, tornando-se uma auxiliar da ciência e da consciência, demonstrando pelos meios que lhe são próprios, a verdade e a justiça que podem encerrar as ações humanas. - E com isto se ligava evidentemente com as acusações de imoralidade que se vinham fazendo contra o Realismo, [...] É no Realismo que se pode fundar a regeneração dos costumes. Deve, pelo menos, tentar-se a regeneração dos costumes pela arte. Quer dizer: quando a ciência nos disser: a idéia é verdadeira; quando a consciência nos segredar: a idéia é justa; e quando a arte nos bradar: a idéia é bela; teremos a obra de arte superior. (SALGADO, 1871, apud MATOS, 1988, p.176)

E serão esses princípios da nova literatura o estopim de muitas controvérsias entre as duas facções literárias que se apresentavam em Portugal. Dias passados, Chagas - eminente porta-voz dos opositores às novas correntes literárias fermentadas em Coimbra - que não assistira à palestra, publica um artigo no Diário de notícias. Nesse, considera que os

\footnotetext{
${ }^{72}$ Ver Berrini, 2000, p.21
} 
realistas não conseguiam exprimir a verdade de sentimentos, pois incorriam no erro de descrever com uma minuciosidade pueril os mais leves acessórios do drama; exemplifica essa argumentação com Madame Bovary de Flaubert. O fragmento abaixo sintetiza muito claramente a resistência de Chagas quanto à nova estética.

Estes anatomistas, que estudam os seus modelos na rígida imobilidade do cadáver assemelham-se porventura ao psicológico profundo que estuda os segredos do coração humano à luz dos relâmpagos tempestuosos da paixão? A paixão! Que fui eu dizer? O Realismo desconhece as paixões; o amor é para eles simplesmente a excitação dos sentidos, todos esses afetos violentos que devastam a alma humana não os aceita senão como umas enfermidades que entram completamente no domínio da medicina; dai lhe provém a impassibilidade que o caracteriza. O romancista é o clínico social, que conta as pulsações do homem no estado febril, produzido pelo amor, ou pela ambição. [...]Para além do campo do vosso microscópio há um mundo que as lentes não alcançam, o mundo moral, o mundo das paixões e dos afetos. Esse é-vos defeso, porque não tendes nem sentimento delicado, nem a indignação das almas nobres, e possui apenas a impassibilidade estulta do frio observador. (CHAGAS, 1871, apud MATOS, 1988, p.177, grifo nosso)

Conforme Simões (1945), a data desse folhetim representará um marco importante quanto às oposições surgidas entre esses dois escritores portugueses durante o último quartel do século XIX, e que durará até a morte do autor de A morgadinha Val Flor. Lembrando que, já na época da Questão coimbrã, Pinheiro Chagas, em suas duas obras direcionadas à crítica literária, ressalta sempre que a escola realista é uma certeza no meio literário de seu tempo. Logo, qualquer ensaio seu era uma oportunidade em divulgar o seu descrédito ao Realismo e os defeitos da nova estética. Em pelo menos dois estudos, em Ensaios críticos $(1866)^{73}$, um sobre Júlio César Machado e o outro de Camilo Castelo Branco, isso fica bem evidente.

\footnotetext{
${ }^{73}$ Os artigos reunidos no livro Ensaios críticos foram publicados nos primeiros anos de jornalismo de Chagas, tanto assim que seu autor os considera como "tentativas de crítica literária". Já os estudos apresentados nos Novos ensaios críticos (1867) são todos inéditos. De forma geral, os artigos são estruturados com uma introdução, desenvolvimento organizado em aspectos histórico-literários, análise de alguns pontos da obra e conclusão sucinta, às vezes até em aberto. É visível a
} 
[...] Eu faço aqui a humilde confissão de que embirro em geral com essa escola, que por aí se chama realista, e que tem querido daguerreotipar fielmente a sociedade com todos os seus vícios, e todos os seus ridículos, escola maldita inaugurada por Balzac de minuciosa memória, e em que tantos talentos se têm perdido. Eu arrepio-me sempre que abro um volume de Balzac, e começo a ver a casa em que tem de se passar a cena do romance. Conduz-me o romancista em passo grave, faz subir a escada, diz-me que o corrimão tem muitas teias de aranha, leva-me à cozinha, não me poupa a descrição nem de uma caçarola, e desgraçado de mim, se encontramos no caminho com a cozinheira, porque tenho de contemplar durante quatro ou cinco páginas o retrato da ilustre sacerdotisa de comus; e tudo isto tão fastiento, tão comprido, que, palavra de honra, (desculpe-me à heresia) quando chego ao quarto da cama, aproveito a idéia do autor e... adormeço!(CHAGAS, 1866, p.101102 , grifo do autor)

Segundo Chagas, os realistas cometiam o engano de se tornarem fisiólogos, em vez de psicólogos. Isto é, o materialismo literário impossibilitava seus cultores de penetrar "no mundo da moral, das paixões e dos afetos". No capítulo destinado a Camilo, é longa também a sua digressão acerca do Realismo. Para Chagas, trata-se de uma literatura que “não produz [...] senão as Fannys ${ }^{74}$ e as Madames Bovarys, [...] não se pode dizer rigorosamente que tenha o mérito do Paulo e Virgínia de Bernardim de Saint Pierre, e da Atala de Chateaubriand" (CHAGAS, 1866, p.13, grifo do autor).

Chamou-nos a atenção, nesse mesmo artigo sobre Camilo, o fato de Chagas enaltecer as qualidades lingüísticas do autor de Amor de perdição e de se referir ao estilo utilizado pelos realistas como "fezes arcaicas".

Pelo que foi discutido até aqui, a principal crítica de Chagas é a preocupação do Realismo em privilegiar o espelho da forma ao invés do espelho íntimo em sua arte. Como

erudição de Chagas, pois ele demonstra muito domínio sobre a história e os clássicos. Procura quase sempre relacionar o assunto literário associando-o com política, identidade nacional, história e filosofia.

${ }^{74}$ Ver Van Tieghen, 1955, p. 344-345. Poucos meses depois da publicação de Madame Bovary (1857) apareceu Fanny (1858) de Ernest Feydeau. Escandalosa estória sobre adultério (mulher casada que se envolve com rapaz mais moço). Muitos a consideram como obra-prima de análise psicológica e de pintura realista, mas, para Van Tieghen, pela qualidade de estilo o romance de Flaubert tem assegurado incontestavelmente superioridade. Em Portugal, Fanny foi traduzida por Camilo Castelo Branco em 1861. 
fica bem evidenciado pelo enorme número de citações desfavoráveis e depreciativas à escola realista e, por outro lado, à defesa incondicional da escola idealista, presente nos artigos-folhetins reunidos posteriormente nos Ensaios críticos (1866).

Não, esta não é, não pode ser a verdadeira literatura [...] [defende a escola idealista] [...] a fonte inesgotável do ideal é e há de ser sempre a verdadeira Castalia da literatura moderna, e esta crença do ideal, que dá a Otávio Feuillet o seu estilo fluente, e opulentíssimo, a Méry a originalidade, que torna deliciosas todas as produções daquele espírito brilhantemente paradoxal, e é, parece-me essa mesma religião, que dá aos folhetins de [Júlio César] Machado, esse estilo tão pitoresco, e tão atrativo, que lhes tem conquistado o justo favor do público. (CHAGAS, 1866, p. 102-103)

Por exemplo, em seu estudo sobre uma das obras de Camilo Castelo Branco, A filha do doutor negro, pelo menos terça parte do texto está diretamente ligada a duras críticas sobre a nova estética. Chagas (1866) chega, por diversas vezes, a interromper o raciocínio sobre a obra de Camilo para incluir censuras ao Realismo, como a do seguinte trecho:

E sabem, por fim das contas, o que essa literatura faz? Forma uma geração, como a geração juvenil que por aí campeia, geração materialista, sem fogo, sem ilusões, e sem experiência, homens de vinte anos com a devassidão torpe, com o egoísmo, com a secura de corações dos velhos, para quem as cãs não são diadema venerando, mas coroa de orgia, geração que não encontra espinhos na vida, porque não quer colher nenhuma flor, só geração de Rastignacs [personagem de Pai Goriot] e de Rubemprés [personagem de Ilusões Perdidas] aperfeiçoados pelo estudo dos seus modelos. [...] Querem que lhes diga o que penso: Pareceme que a escola idealista consegue, sem ter a isso pretensões, ser mais verdadeira do que a escola realista. (CHAGAS, 1866, p.11-14)

Para Chagas, a genialidade de Camilo passeou nas duas margens, tanto na escola idealista quanto na realista, e em ambas deu provas do seu vasto talento. No entanto, ele considera que Camilo fora mais feliz nas investidas da primeira escola, pois se pode constatar uma maior autenticidade nas personagens e narrativas das obras camilianas ligadas a essa escola. 
Depois de exposta a síntese de Pinheiro Chagas sobre o Realismo, gostaríamos de apontar que existem similitudes entre essas idéias e as concepções de Machado de Assis sobre esta estética. Parece-nos que Machado ([1878]1938) também compartilha dos questionamentos de Chagas quanto à supervalorização do acessório em detrimento da análise da natureza humana. Como se apresentam em um dos fragmentos que extraímos do artigo de Chagas sobre Ramalho Ortigão, um dos integrantes da "nova geração": "O romance não é tanto o espelho como o pulso da sociedade; não avaliemos tanto o mundo parisiense pelos quadros repelentes que dele nos apresentam os modernos romancistas, como pela voga que esses romancistas adquirem. [...]”.(CHAGAS,1867,p.266). Machado, em 1878, envereda-se pelas mesmas advertências aos adeptos do Realismo que, equivocados, priorizavam descrever minuciosamente e excessivamente a matéria, prejudicando com isso a estrutura interna da narrativa.

[...] Não se conhecia no nosso idioma aquela reprodução fotográfica e servil das coisas mínimas e ignóbeis [...], pois trata nos de repelir a doutrina, não o talento, menos o homem - em que o escuso e o torpe era[m] tratados com um carinho minucioso e relacionados com uma exação de inventário. [...] Porque a nova poética é isto e só chegará à perfeição no dia em que nos disser o número exato dos fios de que se compõe um lenço de cambraia ou um esfregão de cozinha. (ASSIS, [1878] 1938, p.162-163)

E como justificativa desses argumentos, o autor de Esaú e Jacó apresenta os defeitos capitais d' O primo Basílio em relação ao destaque que Eça dá ao pormenor (as cartas de Juliana) no primeiro plano da ficção, sendo que essas ao serem retiradas por qualquer eventualidade da narrativa, a única coisa que resta ao escritor seria fechar o seu livro.

[...] Que os três [a descrição do cenário à porta da confeitaria quando das confidências de Juliana a Sebastião, a transcrição do personagem Henri Monnier no longo jantar do Conselheiro Acácio e o capítulo do teatro de

S. Carlos] estão acabados com muita arte, sobretudo o primeiro, é coisa 
que a crítica imparcial deve reconhecer; mas, por que avolumar tais acessórios até o ponto de abafar o principal?

Talvez estes reparos sejam menos atendíveis, desde que o nosso ponto de vista é diferente. O sr. Eça de Queirós não quer ser realista mitigado, mas intenso e completo, e daí vem que o tom carregado das tintas, que nos assusta, para ele é o tom próprio. Dado, porém, que a doutrina do Sr. Eça de Queirós fosse a verdadeira, ainda assim cumpria não acumular tanto as cores, nem acentuar tanto as linhas; e quem o diz é o próprio chefe da escola, de quem li, há pouco, e não sem pasmo, que o perigo do movimento realista é haver quem supunha que o traço grosso é o traço exato. Digo isto no interesse do talento do Sr. Eça de Queirós, não no da doutrina que lhe é adversa, porque a esta o que mais importa é que o Sr. Eça de Queirós escreva outros livros como $O$ primo Basílio. Se tal suceder, o Realismo na nossa língua será estrangulado no berço e a arte pura, apropriando-se do que ele contiver aproveitável (porque o há, quando se não despenha no excessivo, no tedioso, no obsceno e até no ridículo, a arte pura, digo eu, voltará a beber aquelas águas sadias do Monge de Cister, do Arco de Santana e do Guarany. (ASSIS, [1878] 1938, p. 172-174)

Nessas exposições, claro está que, tanto para o crítico português quanto para o brasileiro, as verdades morais não poderiam ser ensinadas pelo materialismo, nem o Realismo seria um meio em descobri-las. Para ambos, Eça e os seguidores de Zola deturpavam a doutrina realista, quando entendiam que o princípio dessa estética estava na descrição minuciosa da realidade. As aproximações entre as duas concepções críticas separadas pelo Atlântico consistiam em estabelecer que a representação do real, para esses adeptos, seria a valorização do acessório, aspecto que não é a essência da arte. No seu artigo, Machado de Assis desenvolve o argumento de que o fundamento da arte realista vai muito além da simples reprodução do modelo, de fato, esse estaria numa verdade estética. Apesar de este não clarificar com mais detalhes esse princípio, fica implícito em seu argumento que o mesmo residiria numa coerência interna da narrativa. Machado também discorda de Eça quanto aos dois romances históricos portugueses citados dentre as obras conceituadas, na sua conferência sobre o realismo, como "arte de todos os tempos menos do nosso". Para o autor de Dom Casmurro, $O$ arco de Santana de Almeida Garrett e $O$ 
monge de Cister de Alexandre Herculano simbolizam a verdadeira arte. Por fim, tanto Chagas quanto Machado explicitam a obra de Shakespeare como modelo de Realismo, profundamente psicológico, que ajudara a desvendar parte da essência humana. Para ilustrar sua argumentação quanto ao Realismo preservando e priorizando a verdade moral, Machado compara a obra de Eça a Othelo, especificamente no caso de Desdêmona. Assim, o autor de Memórias póstumas de Brás Cubas discute:

Tirai o extravio das cartas, a casa de Jorge passa a ser uma nesga do paraíso, sem essa circunstância, inteiramente casual, acabaria o romance. Ora, a substituição do principal pelo acessório, a ação transplantada dos caracteres e dos sentimentos, para o incidente, para o fortuito, eis o que me pareceu incongruente e contrário às leis da arte.

[...] O lenço de Desdêmona tem larga e a inocência de Desdêmona, eis os elementos principais da ação. O drama existe, porque está nos caracteres, nas paixões, na situação moral das personagens: o acessório não domina o absoluto, [...] Extraviem-se as cartas, faça uso delas, Juliana; é um episódio como qualquer outro, mas o que, a meu ver, constitui o defeito da concepção do Sr. Eça de Queirós é que a ação, já despida de todo o interesse moral, adquire um interesse anedótico, um interesse de curiosidade.(ASSIS, [1878] 1938, p.178-179, grifo nosso)

A exaltação do acessório para o primeiro plano da obra favorece em pelo menos um defeito capital, a ausência psicológica das personagens. Para Machado, Luiza de Eça é símbolo desta conseqüência, e de nada se aproxima à densidade psicológica de uma das personagens de Balzac, Eugênia Grandet.

[...] de modo nenhum plagiou os personagens de Balzac. A Eugênia deste, a provinciana singela e boa cujo corpo, aliás robusto, encerra uma apaixonada e sublime, nada tem com a Luiza do Sr. Eça de Queirós. Na Eugênia há uma personalidade acentuada, uma figura moral, que por isso mesmo nos interessa e prende. [...] a Luíza é um caráter negativo e, no meio da ação ideada pelo autor, é antes um títere do que uma pessoa moral. [...] não lhe peçam paixões, nem morais, menos ainda consciência. Para que Luiza me atraia e me prenda, é preciso que as tribulações que as afligem venham dela mesma; seja uma rebelde ou uma arrependida, tenha remorsos ou imprecações, mas por Deus! Dê-me a sua pessoa moral [...] Porque sabemos que a catástrofe é o resultado de uma 
circunstância fortuita, e nada mais; e conseqüentemente por esta razão capital: Luiza não tem remorsos, tem medo. (ASSIS, [1878] 1938, p.165)

Régio, em 1945, irá retomar esse assunto reafirmando-o. Para este autor, o perfil caricaturista de Eça - que se deleita com grande demora em toda sorte de pormenores, acidentes e circunstâncias - impossibilita-o de construir moralmente suas personagens.

Por exemplo: Dizer-se que Eça de Queirós não é relevantemente psicológico, poderá parecer absurdo a muita gente. Porém, a verdade é que o não é. Com isto não quero afirmar que não possua certa forma de imaginação psicológica necessária quer à efabulação dos seus conflitos, quer à construção das suas caricaturas. Simplesmente, os seus conflitos ou não são dos que exigem excepcional penetração psicológica, fundamental riqueza de vida interior, ou não aparecem desenvolvidos no sentido de as exigir. Quanto ao talento de caricaturista - notabilíssimo no Eça - julgo poder entender toda a gente que não pressupõe nenhuma visão particularmente penetrante das sutilezas e minudências da coisa caricaturada. Pressupõe, sim, apreensão dos seus traços e feições marcantes. (REGIO,1955, apud LISBOA, s.d, p.185)

Para Régio (1955), Eça, várias vezes, elogiou o Realismo por extrair a verdade por meio da arte, mas nunca se especializou em ver a realidade plena. Dela viu, porém, os aspectos que melhor enquadravam a sua imaginação toda inclinada para o sentido cômico e satírico da sociedade. E esse traço marcante na obra de Eça o fez, por diversas vezes, segundo Régio, ser considerado erradamente como grande psicólogo.

Concluindo, é visivelmente perceptivo que, para os adeptos do Realismo, esse era um movimento estético integrado ao espírito revolucionário, principiado em 1789. Tratava-se de uma agitação de caráter eminentemente moral, que pretendia que a arte contribuísse para se chegar à justiça, à verdade e ao belo.

Veremos, a seguir, que temas apresentados nas Conferências do Cassino pelos integrantes da nova geração serão no futuro palco de polêmicas entre Eça e Pinheiro 
Chagas. Como foram resgatadas, por exemplo, as idéias das causas das conquistas e a valorização da raça portuguesa na polêmica Brasil e Portugal. 


\section{Pinheiro Chagas e Eça de Queirós: Entre controvérsias patrióticas e literárias}

As polêmicas do período oitocentistas aconteceram sob qualquer tipo de pretexto, pelo simples fato de ganharem notoriedade e, em última instância, como meio de exercitar a sua retórica e demonstrar a sua erudição. Assim, os polemistas se opunham sem que houvesse justificativas plausíveis de seu engajamento em uma controvérsia, visando somente a sua projeção literária e social. Com o fortalecimento da imprensa, as polêmicas se avolumaram e se tornaram cada vez mais constantes no folhetim, tudo era motivo de discussão. Ventura (1991) considera que

A polêmica é [...], como forma de debate, marcada pelo predomínio da retórica e pela irrelevância dos assuntos tratados. [...]. A sátira à retórica e a polêmica faz parte da crítica ao personalismo do debate cultural e político, a serviço não da idéia, mas da glória e renome do orador, que encobre a vacuidade do pensamento pela diç̧ão elevada e linguagem empolada. (VENTURA, 1991, p.105)

Nas polêmicas, o padrão reflexivo dos contendores - definido pelo caráter de réplica e o desejo de revide ao seu oponente - gera um certo exagero retórico e teatral de suas diferenças e oposições, pelo qual cada um dos polemistas se esforça em manter a originalidade de suas concepções no cenário cultural. As polêmicas sempre se desenrolam com o olhar voltado para as reações do público e a recepção do debate. Durante a contenda, o debatedor apresenta uma retórica dentro de uma interlocução bifurcada, explicada pela alternância de destinatários, ora o oponente, ora o leitor. Não nos esquecendo de que “o 
inimigo" é o intermediário do processo comunicativo entre o polemista e seu público, já que um dos objetivos da polêmica é conquistar a simpatia e a adesão deste à causa do orador. $^{75}$ Já a posição de árbitro na disputa é destinada ao leitor. A platéia, campo em princípio neutro, sofre influências tanto do discurso persuasivo do locutor, quanto o do seu adversário.

Outra característica da polêmica é o seu caráter jurídico, pois cada um dos debatedores advoga em causa própria, como se estivessem diante de um júri imaginário. Esse, na verdade, é formado por uma platéia encarregada de assistir à apresentação e exposição das partes. Por outro lado, esse mesmo júri de leitores não está autorizado a declarar quando se encerra uma contenda, ficando sempre a cargo dos debatedores. Por isso, o processo de julgamento, em muitas delas, permanece em aberto por longos anos, devido à intensa carga de digressões e vacuidade retórica por parte dos seus interlocutores.

Antes de passarmos propriamente ao estudo da polêmica Brasil e Portugal, queremos dialogar um pouco com a teoria de Bourdieu (2004) sobre as relações de poder existentes em todos os campos sociais. Na sua teoria, Bourdieu aborda que as práticas sociais se dão especificamente dentro de um espaço determinado, denominado "campo", definido estruturalmente a partir das posições de poder e trocas simbólicas que não dependem da vontade dos ocupantes nessas posições. Para este sociólogo, o poder simbólico seria uma forma legitimada e transfigurada de outras formas de poder, que transforma as diferentes espécies de capital em capital simbólico. As pessoas buscam transformar em capital simbólico as suas outras espécies de capital, objetivando conquistar os outros, para depois contarem com eles. Dessa maneira, para que se tornem possíveis as relações sociais, ou nos termos bourdieunianos, "se dê o jogo" é fundamental que haja uma razão, um "objeto de

\footnotetext{
${ }^{75}$ Ver Ventura, 1991, p.148
} 
desejo" que incentive os jogadores e os leve a seguir as regras já previamente conhecidas desse campo. Relacionando as idéias de Bourdieu com os interesses dentro do universo polêmico, entendemos que ambos os interlocutores acordam nas regras, demolir o oponente por meio da retórica, na disputa do mesmo objeto de desejo, a adesão do público a sua causa e, conseqüentemente, a notoriedade, que seria o capital simbólico, depois da derrota de seu oponente.

Dados esses pressupostos, voltemos nosso olhar à polêmica Brasil e Portugal, querela centrada no conceito de patriotismo, tendo como protagonistas Eça de Queirós e Pinheiro Chagas. Podemos antecipar que se estabelece aqui, nessa questão, mais uma disputa incitada pelo poder intelectual, do que realmente por razões ideológicas, teóricas ou morais. Logo, Eça, conhecedor da erudição de Chagas, escolheu as melhores armas para desestabilizar não somente suas argumentações, mas também construir um esboço caricato deste que, posteriormente, imortalizou em sua ficção.

De outro lado, Campos Matos (1988) sinaliza que as controvérsias com Pinheiro Chagas teriam dado a Eça evidente prazer, provocados pelo humor, estilo e ironia com que replicava ao autor de A morgadinha Val Flor. Autores como Régio (1945 apud Lisboa, s.d) e Campos Matos (1988) nos advertem que não se pode negligenciar que Eça, nas polêmicas, tinha em mente uma estratégia combativa, a desmoralização do seu oponente ideológico por meio da crítica pelo riso, ou do raciocínio pela ironia. Se a polêmica era a possibilidade de expor e defender em público suas idéias, nada melhor do que exercitar sua veia satírica por meio daquilo que Eça caracterizou como a filosofia do riso. Para o autor de Os Maias,

O riso é a mais útil forma da crítica, porque é a mais acessível à multidão. $\mathrm{O}$ riso dirige-se não ao letrado e ao filósofo, mas à massa, ao imenso público anônimo. É por isso que hoje é tão inútil como 
irreverente rir das idéias do passado: a multidão não se ocupa de idéias, ocupa-se das fórmulas visíveis, convencionais das idéias. (QUEIRÓS, $N C$, s.d, p.1389, grifo nosso)

Notemos que Eça tem nítido para si que o público é seduzido não por idéias, mas por aquilo que lhe é acessível e visualmente imposto. E o dom realista de abstrair os pormenores de uma realidade dava a Eça o meio necessário para descrever burlescamente a concepção patriótica e a notoriedade de Chagas durante esta polêmica. Lembrando que o caricaturista Eça ao deformar a realidade de Chagas - ressaltando-lhe as formas no sentido do cômico, do grotesco e do repulsivo - ganha o público por meio da troça, obtendo, a partir disso, mais destaque no cenário cultural.

Recordemos, portanto, a controvérsia. As reminiscências da polêmica Brasil e Portugal começam já em 1872, numa publicação de As farpas. Nesta, Eça retruca a uma reflexão de Chagas publicada no Diário de notícias sobre escritores que fustigavam a pátria. No artigo de Eça, que leva o nome de seu destinatário, seu autor constrói tão jocosamente a sua argumentação que é inevitável não pensar no ridículo estado de Chagas vivendo num país ficcional.

Parece que, segundo o feliz Pinheiro Chagas, nós temos todos os bons livros, toda a perfeição de leis, toda a abundância de riquezas, toda a virtude pública, toda a elevação de caráter, toda a beleza de formas como aquela cidade ideal onde o jovem Telêmaco e o calvo mentor passeavam coroados de loiros, trocando as prosas monótonas com que o puro Fénelon ${ }^{76}$ lhes besunta alternadamente os beiços.[...] E sabem quais são as provas que o nosso espirituoso amigo dá deste estado de perfeição platônica, desta superioridade inacessível às raças inferiores? Duas provas: termos descoberto o caminho da Índia. Termos com a nossa energia, domado o Indostão.(QUEIRÓS, UCA, s.d, p.1155)

\footnotetext{
${ }^{76}$ Cf. Dicionário Enciclopédico Luso Brasileiro, 1974, p.983. Francisco de Salignac de La Mothe Fénelon (1651-1715), ilustre acadêmico e prelado francês que compôs para o seu pupilo Duque de Borgonha, neto de Luís XIV, dentre outras obras, Telêmaco. Esse livro é cheio de alusões indiretas ao governo de Luís XIV e cuja publicação em 1699 fez com que caísse em desagrado. Fénelon, de caráter e tendência muito aristocráticos, mostrava-se em oposição ao absolutismo do rei. Espírito delicado, muitas vezes quimérico, Fénelon é um escritor muito hábil, mais sedutor do que eloqüente, muito influenciado pela antiguidade grega, de estilo suave e florido.
} 
Visualiza-se nesse trecho, aquilo que Figueiredo (1940) considera como divergência ideológica entre os Ultra-românticos e os Realistas quanto ao patriotismo. Enquanto que aqueles se dedicavam às glórias do passado por meio de um patriotismo retoricamente otimista, estes se interessam pela problemática da vida moderna, de forma mais cética. Para o grupo de Eça, a postura dos primeiros só contribuía para que se camuflasse mais a decadência de Portugal, por meio de um patriotismo desprovido de idéias. Eça, nesse fragmento acima, coloca-se contrário às concepções de Chagas sobre a pátria, soberania e independência nacional. Dessa maneira, para Eça, Chagas considerava todo aquele que julgasse Portugal decrépito estaria ofendendo a pátria. 


\title{
2.1.
}

\section{Uma querela patriótica: Brasil e Portugal}

O "chauvinismo" de Chagas, assim entendido pelos integrantes da geração de 70, principalmente por Eça de Queirós, nos episódios da Comuna de Paris e no fechamento das Conferências do Cassino, vai novamente entrar em liça na polêmica denominada Brasil $e$ Portugal, em 1880. Em 31 de outubro, a Gazeta de notícias do Rio de Janeiro publica a crônica de Eça, um artigo do Times sobre o Brasil ${ }^{77}$. Nesse texto, como apresentamos por meio dos fragmentos abaixo, seu autor faz duas afirmações históricas, a primeira de que Portugal fora colônia do Brasil:

\begin{abstract}
Nunca fomos decerto para o Brasil senão amos amáveis e timoratos. Estávamos para com ele naquela melancólica situação de um velho fidalgo, solteiro, arrasado, desdentado e trôpego, que treme e se baba diante de uma governanta bonita e forte. Nós verdadeiramente é que éramos a colônia: e era com atrozes sustos do coração, que entre uma salve-rainha e um lausperene, estendíamos para lá a mão à esmola.[...]. (QUEIRÓS, CI, s.d, v.II, p.594, grifo do autor)
\end{abstract}

E a segunda de que houve atos de barbárie na dominação das Índias: “ [...] Talvez é bom com o império do Oriente no nosso passado, que é um dos mais feios monumentos de ignomínia de todas as idades [...]. ”(IBIDEM, p.594).

Segundo Campos Matos (1988), Pinheiro Chagas fica indignado e escreve um artigo em $O$ atlântico no dia 28 do mês seguinte, replicando a Eça de Queirós de ter escrito uma irritada descompostura à pátria para um jornal brasileiro. Na abertura de seu artigo, Chagas

\footnotetext{
${ }^{77}$ Este texto foi coligido postumamente nas cartas de Inglaterra com o título Brasil e Portugal.
} 
reconhece o talento do autor de $O$ primo Basílio, mas desmerece as qualidades de historiador que Eça empreende no seu texto.

Eu sou um dos mais ferventes admiradores de Eça de Queirós, detesto as suas teorias literárias, mas adoro os seus romances, que felizmente só em algumas páginas se conformam com suas teorias. Admiro, sobretudo, a exuberância de sua veia satírica, a originalidade da sua linguagem, o poder verdadeiramente surpreendente do seu estilo. [...]

Não é precisamente no Chiado $^{78}$, nem em Bristol que se aprende História portuguesa. Ninguém exige do Sr. Eça de Queirós que seja um Taine, quando é já um Flaubert; mas também ninguém lhe exige que faça crítica histórica, quando melhor pode empregar o seu tempo em fazer romances esplêndidos, ou em escrever folhetins de um humorismo arrebatado. (CHAGAS, apud MATOS, 2001, p.43)

Chagas desabilita a exposição historiográfica do texto do Times. Para ele, a crítica histórica não poderia ser um campo explorado por iniciantes, a história deveria ser tratada com rigor científico. Talvez essa crítica de Chagas tenha sido a que mais aborrecera Eça.

Diante da constatação já sinalizada por Campos Matos (2001) de que Eça teria levado a melhor nestas disputas, entendemos que as cartas ecianas deverão estar no primeiro plano de nossas discussões, já que serão por meio delas o início da paródia da vida de uma das mais importantes figuras do Portugal oitocentista ${ }^{79}$, Pinheiro Chagas. Como referência ao nosso trabalho, seguiremos a estrutura analítica de retórica proposta por Campato (2003) em seu criterioso estudo sobre as cartas de Alencar referentes à polêmica, A confederação dos Tamoios $^{80}$. Antes de tudo, podemos dizer que a controvérsia Brasil e Portugal abrange

\footnotetext{
${ }^{78}$ Cf. Valdemar, 1989, p. 45-63 O Chiado, bairro literário onde aconteciam as reuniões de poetas nos muitos cafés. De Alexandre Herculano a Aquilino Ribeiro, ali se reuniram ao fim da tarde e ao começo da noite inúmeras personalidades que marcaram o perfil intelectual e político de Portugal. O Cassino Lisbonense, a Casa Havaneza e o Teatro de São Carlos são alguns dos lugares presentes no Chiado.

${ }^{79}$ A dificuldade de acesso ao espólio literário de Chagas em seus originais nos demonstra que, indiscutivelmente, diante das polêmicas travadas com Eça, Chagas foi demolido e apagado. Os seus textos quando recuperados os são por biógrafos de Eça ou dos outros escritores da Geração de 70, com a clara intenção de recortar somente aquilo que expressaria uma contradição às idéias inovadoras dessas personalidades literárias.

${ }^{80}$ Cf. Campato, 2003, p.11. Alencar como grande polemista que era, nessa empresa, tenta demolir o ícone da literatura nacional, José Gonçalves de Magalhães. Para isso, utiliza-se de cartas sob o pseudônimo, Ig, para desacreditar a obra de Magalhães - considerada na época como a primeira epopéia nacional. Ao apontar-lhe os defeitos e afirmar o distanciamento dessa obra com a realidade nacional, Alencar, de certa forma, prepara o terreno para a espera de outro
} 
uma dupla feição, a epidítica ${ }^{81}$ e judiciária. A primeira na forma como Eça censura a vaidade e o cabotinismo de Chagas diante da história nacional. Os efeitos desejados depois que se utiliza esse tipo de estratégia retórica é a admiração para o orador e, por outro lado, o desprezo de seu oponente. A outra concerne no fato de Eça, ao se defender, dissimular uma condição de injustiçado, já que, a seu ver, Pinheiro Chagas tinha uma idéia fixa de difamá-lo junto a Portugal. Contudo, a autodefesa é, ao mesmo tempo, o ataque quando se trata de polêmicas, pois muitos dos erros que o polemista aponta no seu adversário se fazem presentes tanto num quanto noutro.

Nessa medida, Eça conclui, em sua réplica datada de 14 de dezembro de 1880, que não teria insultado a pátria portuguesa nestas passagens. E responde a Chagas com um texto predominantemente satírico e sarcástico, alternando suas argumentações com uma estrutura ficcional. O autor de A ilustre casa de Ramires, responde com uma prosa histórica, criando um cenário típico do século XVII para Chagas na figura de um brigadeiro. Durante toda a narrativa da carta, Eça mantém o tom de amistosa brincadeira, cobrindo de ridículo o adversário, ao caracterizá-lo como representante anacrônico de um patriotismo ostentoso e antiquado. Há até um certo cuidado histórico de Eça em compor o círculo de amigos de Chagas nessa época. Dentre esses estão Pina Manique, num sarau do marquês de Marialva, a jogar gamão com monsenhor da Patriarcal. Nesse caso, a força do cômico vai aumentando gradativamente com a mistura dos planos, do real e do imaginário.

escritor. Aquele que, por merecimento literário, ocupe o posto de líder das letras nacionais, nesse caso, fortemente representado pelo próprio se considerarmos suas digressões e argumentações literárias sobre os defeitos capitais da obra de Magalhães.

${ }^{81}$ Ibidem,2003, p.129-140. Há três gêneros aristotélicos: o deliberativo que concerne em aconselhar; o epidítico que tem como características louvar e censurar os vícios/virtudes, belezas/defeitos etc e o judiciário que acusa ou defende, incidindo sobre os fatos passados, tendo como objetivo fundamental o justo ou injusto. Nesse último, o auditório condena ou absolve. 
Essa polêmica, diferentemente daquela sobre A relíquia, é feita por meio do discurso direto, sendo seu destinatário o próprio Chagas. No início da carta, antes de apresentar o cerne da questão, Eça diz ironicamente estar dilacerado e demolido pelas considerações do primeiro texto de Chagas, que lhe parece ter sido feito “ [...] com arte, com eloqüência, com luxos de atitude, com elegâncias sábias de belo atleta.” (QUEIRÓS, NC, s.d, v.II, p.1393). Esse trecho tem duas facetas, para o leitor mais ingênuo pode parecer um elogio, que de forma mais persuasiva dá ao orador mais crédito diante do público, já que ele, com imparcialidade, também reconhece virtudes em seu adversário. Então, quando orador apontar os defeitos estes também serão feitos com honestidade de julgamento. Contudo, por trás desses termos elogiosos ao artigo de Chagas, transparece todo o poder eciano de escárnio.

\begin{abstract}
Meu caro Pinheiro Chagas: - Recebi o número do Atlântico contendo o seu excelente artigo - Brasil e Portugal. [...]

Evidentemente, porém, o homem que lhe escreve não é aquele que você há meses abraçava, inteiro e intacto, à esquina sagrada da Casa Havanesa; esse [o] demoliu você, desmantelou-o com as três pesadas colunas do Atlântico, brandidas às mãos ambas num esforço intumescido de Sansão.

Assim você me esmaga sob pedregulhos desproporcionados: [Faz uma síntese da crítica de Chagas sobre o seu artigo] [...] .

Porque a hediondez da sua ferocidade não exclui, meu caro Pinheiro Chagas, a excelência do seu talento. Mas sinceramente, você foi excessivo. Desde que recebi o seu Brasil e Portugal, de chofre, tenho estado ocupado em apanhar laboriosamente, aqui e além, pelo chão, os pedaços de mim mesmo. Tão violentamente, porém, me despedaçou você, que não consigo reconstruir-me: não sei, por exemplo, onde pára a minha perna direita; [...] e é apenas com dois dedos e meio que eu estou traçando estas regras [...].Toda essa indignação, meu caro Chagas, foi provocada ao que parece (porque o caso é obscuro) por ter eu, segundo você proclama, 'injuriado e descomposto Portugal'.[...].(IBIDEM, p.1394)
\end{abstract}

Nesse exórdio, depois de ler a argumentação histórica de Chagas, já se percebe a intenção zombeteira de Eça de inverter as posições de vencedor e vencido quanto à 
erudição histórica entre ambos nessa controvérsia. Uma das principais conseqüências dessa estratégia retórica é conquistar o público, ao estabelecer que ele, Eça, não se crê como dono de nenhuma verdade histórica. O autor de Os Maias, ao tomar uma postura de impotência e inferioridade afetadas, confere a seus leitores provas de sua honestidade e humildade, necessárias ao processo de persuasão ${ }^{82}$. Por outro lado, essa artimanha produz, no imaginário do público, a imagem de um Chagas eruditamente arrogante.

Outro estratagema na carta eciana, para nós, o maior deles empreitado por Eça, é desqualificar o domínio histórico de Chagas, já que a disputa ocorria no campo do adversário que era um historiador renomado. Daí, o grande jogo de ironias em lugar de argumentos, a utilização de muita verve em lugar de expor raciocínios coerentes. Dessa maneira, é mais do que justificável a idealização caricata de um Chagas que domina a história não porque é um experto, mas por ser um narrador maçante do tempo que vivenciou.

Donde eu concluo, meu caro Chagas, que você, apesar de habitar a Lisboa contemporânea de 1880, é realmente um velho personagem do século XVII, com mais de 145 anos de idade, pintado por fora duma cor natural de vida moderna, mas ressequido e pulverulento por dentro, que tendo escapado milagrosamente aos anos e às revoluções anda agora entre nós representando os modos de pensar e de falar que caracterizam a sociedade portuguesa do tempo da senhora D. Maria I.(QUEIRÓS, $N C$, s.d, v.II, p.1394)

O valor epidítico apresenta elevada importância na medida em que atua como demolidora da reputação do historiador Chagas. Parece-nos que Eça, ao empregar a ficção burlescamente histórica em seu artigo, estaria colocando em xeque as conclusões de Chagas quanto ao seu próprio domínio histórico. Eça ao desenhar minuciosamente a caricatura do autor da História de Portugal por meio da dramatização - o que não deixa de

\footnotetext{
${ }^{82}$ Cf. Campato, 2003, p.143. Aristóteles considerava que geralmente costumamos dar atenção àqueles que nos demonstram honestidades.
} 
ser uma técnica realista - faz surgir na consciência do leitor uma imagem cômica da realidade. É claro que o pequeno conto histórico dentro desse artigo, se assim podemos considerar, trata-se de uma paródia da vida política e literária do seu oponente. Eça ri do anacronismo da figura de Chagas, por meio de zombarias ficcionalizadas, que vão destruindo a um só tempo a figura do político, historiador, crítico e prosador:

Você se lembra do tipo? Eram aparatosos e formidáveis; tinham estado no Roussilhão; nas festas de família, noivado ou dia de anos, eram eles que se erguiam à sobremesa e com uma lágrima no bigode, batendo sobre o coração, falavam do velho Portugal! Possuíam opiniões; e não compreendiam que o Estado fizesse outra coisa que espanejar os louros de Arzila, nem que o pensamento passasse além das maravilhas da "Nova Castro". Decrépitos, comandando três veteranos num forte, ainda todas as manhãs, depois da sua genebra, batiam furiosamente com a bengala nas lajes, e queriam tragar o Mundo. Excelentes almas! Deixavam sempre dinheiro a uma sobrinha, e sabiam deitar fundilhos nuns calções. Odiavam o pedreiro-livre; atribuíam-lhe todos os males da pátria; e, para eles, fazer a crítica histórica do passado era ofender as glórias da nação! - Você é o último desta nobre raça. Bem sei, bem sei o que o meu caro Chagas me vai dizer: 'E os meus livros? Os meus trabalhos? As minhas opiniões liberais? A minha democracia ...' Eh, meu caro Pinheiro Chagas, os seus livros ninguém os admira mais do que eu! E folgo dizê-lo aqui. Vejo-o há mais de dez anos na brecha, lutando, forjando o romance, o drama, o verso, a crítica, a história - e enche-me de respeito uma vida moça, agitada assim dum tão vasto labor intelectual.(QUEIRÓS, $N C$, s.d, v.II, p.1396, grifo nosso)

Essa imagem caricatural dum brigadeiro que comanda três veteranos, batendo nas lajes não com a espada, mas com a bengala, e sabe deitar "fundilhos nuns calções" expressão que nos parece deixada propositadamente para o fim da frase, para que a atenção do leitor nela se concentre - serve a Eça maravilhosamente para pôr a ridículo a valentia e o patriotismo retóricos de todos aqueles que ele simbolizou nesse brigadeiro, principalmente seu destinatário. Nesse trecho, é visível como Eça desloca a atenção do auditório por meio da troça daquilo que deveria ser verdadeiramente o cerne da questão, 
conhecida por meio da sentença, "fazer a crítica histórica do passado era ofender as glórias da nação".

Como podemos constatar, a origem da designação caricatural de "Brigadeiro do tempo de D. Maria I" surge numa estrutura ficcional dentro de um artigo-resposta. Já discutimos anteriormente que o uso de epítetos é bastante usual no meio literário, em se tratando de polêmicas.

Já em baixo tilintavam os guizos das liteiras. Saiu-se. E foi você que, chegando-se ao senhor arcebispo de Tessalônica, e querendo resumir numa palavra todo o mundo de verdades e de idéias que se agitara nesse sarau, o esplendor intelectual que aí brilhava e para que você concorrera - disse respeitosamente ao prelado:

- Portugal é pequenino, mas é um torrãozinho de açúcar.

E sua eminência replicou, depois de arrotar:

- Tem razão, brigadeiro Chagas.

Brigadeiro, sim! Brigadeiro do tempo da Senhora D. Maria I! O último brigadeiro patriota!(QUEIRÓS, NC, s.d, v.II, p.1396, grifo nosso)

Esse trecho é um dos mais significativos na polêmica Brasil e Portugal no que se refere ao chauvinismo e ao cabotinismo de Chagas. Lemos (s.d) dispensa considerações sobre aquilo que Eça denominou como patriotismo desmedido, muito ligado à glória pessoal e a outros interesses em benefício próprio do que verdadeiramente aos problemas da nação. Para Eça, esse tipo de patriotismo estaria a serviço da vaidade e do exibicionismo, indícios que teriam determinado a carreira de Chagas como escritor patriota. Aqui, podemos afirmar aquela proposição de que se reprova no adversário aquilo que o orador tem como objeto de desejo, a notoriedade.

E o curioso é que você tornou-se brigadeiro (ninguém o nasce) com as intenções mais belas e mais generosas. Como todo o espírito ativo e ambicioso, quando você começou a sua carreira, desejou distinguir-se e destacou da geração sua contemporânea por uma originalidade forte. [...] Mas, além disso, você imediatamente compreendeu que no meio de tal geração, de tal mocidade, de tal literatura, a alta originalidade, o grande 
relevo, estaria nisto - ser patriota. Desde esse momento você possuía a sua especialidade, a sua nota individual, o seu campo próprio a cultivar $-o$ patriotismo. E com que sofreguidão, meu caro Chagas, você se apoderou dessa mina de ouro! Pudera! É que o patriotismo seria daí por diante para si não só uma doutrina, mas um assunto! Assunto para drama, para ode, para folhetim, para discurso, para grito, para soluço! Enfim, o patriotismo era a sua magnífica carreira. (QUEIRÓS, $N C$, s.d, v.II, 1397, grifo do autor)

Em muitas passagens do texto da polêmica Brasil e Portugal, Eça traça comparações. Aqui neste fragmento, especificamente, há uma, entre as qualidades de Chagas e a dos integrantes da geração de 70, que acaba fazendo com que Eça acentue a mediocridade do autor d'A morgadinha Val Flor. Dessa forma, a sua carreira de patriota eloqüente não passa de um subterfúgio para a fama pessoal. Vejam como o tom elogioso de Eça, nesse trecho, decai cada vez mais a notoriedade da figura de Chagas. Eça poderia até não admirar o espólio literário e a atividade política de Pinheiro Chagas, mas reconhecia a sua popularidade. Se assim consistia, tinha ele, portanto, a missão de desacreditá-lo diante do público que certamente consumia os folhetos da polêmica. De certa forma, ao depreciar Chagas, Eça não deixava de fazer seu próprio marketing pessoal. Sendo que um dos pontos discutidos pelo autor de Os Maias centraliza-se na premissa de que Chagas não perdia a oportunidade de intrigá-lo com Portugal quanto à questão do patriotismo.

No campo argumentativo deste artigo eciano, a questão do patriotismo é freqüentemente contestada. Eça nos indica dois tipos deste. Um que respeita a tradição, mas tem seu foco na nação viva, ou seja, na pátria contemporânea, dispensando-lhe toda verdade necessária para sua transformação cultural, social e política. E o outro de teor puramente retórico, aquele que apenas analisa a pátria à distância. Neste, a nação estará sempre presente em seus discursos parlamentares, em versos e prosas. Evidentemente, Eça descreve o segundo tipo de patriotismo para Chagas. 
Há em primeiro lugar o nobre patriotismo dos patriotas: esses amam a pátria, não [lhe] dedicando estrofes, mas com a serenidade grave e profunda dos corações fortes. Respeitam a tradição, mas o seu esforço vai todo para a nação viva, a que em torno deles trabalha, produz, pensa e sofre: e deixando para trás as glórias que ganhamos nas Moluscas, ocupam-se da Pátria contemporânea, cujo coração bate ao mesmo tempo que o seu, procurando perceber-lhe as aspirações, dirigir-lhes as forças, torná-la mais livre, mais forte, mais culta, mais sábia, mais próspera, e por todas estas nobres qualidades elevá-la entre as nações. [...] O outro patriotismo é diferente: para quem o sente, a pátria não é a multidão que em torno dele palpita na luta da vida moderna - mas a outra pátria, a que há trezentos anos embarcou para a Índia, ao repicar dos sinos, entre as bênçãos dos frades, a ir arrasar aldeias de mouros e traficar em pimenta. Esse, a sua maneira de amar a pátria é tomar a lira e dar-lhe lânguidas serenadas. Esse sobe à tribuna do Parlamento ou ao artigo de fundo, e de lá exclama, com os olhos em alvo e o lábio em luxúria: Oh pátria! Oh filha! Ai, querida! Oh pequena! Que linda és! [...] não ama a pátria, namora-a. [...]. (IBIDEM, p.1398-99)

Como não poderia deixar de ser, a comparação irônica e depreciativa entre os dois tipos de patriotismos estabelece para Chagas o decorativo, aquele que deve ser rechaçado pelo leitor. E, Eça ao estabelecer entre eles essa espécie de intercâmbio de valores, indiretamente, sugere que Chagas também deva ser vilipendiado, minando novamente, com isso, a reputação do seu oponente. De certa forma, os argumentos de Eça por meio da comparação apresenta o duplo caráter epidítico e deliberativo. Ele, ao mesmo tempo, censura a escolha de Chagas e o aconselha de forma sutil a aderir ao tipo de patriotismo mais condizente a um notável historiador.

Já em outro momento, Eça constrói novas comparações. Os reparos deste, apesar de aparentar uma condição de vencido, não o são, pelo contrário, desempenham uma função estratégica no processo que visa à desqualificação do historiador. Isto é, na medida em que Eça expõe a humilhação que sofre pela intransigência de Chagas quanto às suas falhas em história, ele ressalta, por outro lado, em seu oponente, os vícios de prepotência e arrogância. Sendo que o leitor duplamente seduzido, primeiro pelo hilariante artigo e 
depois pelo discurso eciano de injustiçado, tomará partido de Eça, representante da parte massacrada pela ostentação do saber histórico de seu desafeto. Chagas, por sua vez, pelo carisma e persuasão do seu opositor, consegue o efeito contrário, a sua desaprovação perante o público.

\begin{abstract}
Não, meu bom Pinheiro Chagas, não, eu não 'descompus a pátria' amo o meu País dum modo diferente, dum modo íntimo - e burguês como eu: é por isso que nos não compreendemos. Não sendo poeta ou orador como o meu caro Chagas, não posso dedicar cantatas à pátria.

Não lhas descrevo, porque temo o seu sarcasmo ... Mas, enfim, para que não seja eu só a rir-me nesta carta - aí entrego à sua justa hilaridade esta ridícula confissão: é verdade, amigo, é verdade, é com um secreto enternecimento que eu vejo por aqui às vezes, em dias de festa pendendo duma humilde janela, sobre o seu formoso campo azul e branco, a venerável imagem das Quinas, que não tem culpa das odes em que serve de rima, nem das arengas em que serve de tropo, e que lá se balança à brisa estrangeira, modesta e grave, como convém a quem viu tanto perigo e tanto mar!...

Você, bem sei, acha isso risível. Mas que diabo! Você é um poeta, um orador, um lutador - e eu sou apenas um pobre homem da Póvoa. (IBIDEM, p.1404)
\end{abstract}

Uma das estratégias mais empregadas por Eça em suas cartas é minar toda a credibilidade do discurso historiográfico e patriota de Chagas. Esse tipo de desqualificação era favorável no sentido de que ao destruir a imagem de seu oponente, Eça se projetava mais no cenário cultural, sem falar que ganhava a simpatia do público.

Confirmada, então, a premissa do distanciamento entre eles quanto às concepções de patriotismo, Eça tecerá a idéia de serem duas concepções diferentes de uma mesma realidade social. Como bem expressa a sua conclusão que arremata a tréplica da polêmica Brasil e Portugal.

[...] somente creio que as nossas admirações - não são as mesmas. Você vive num mundo fictício, convencional, artificial, por que eu apenas me posso interessar como artista, seguindo-o com um olhar curioso e triste, nesse declive por onde ele vai rolando aos abismos: por outro lado o mundo mais vivo e real, a que eu pertenço, vê-o apenas você através dum vago nevoeiro mental que lhe falseia a proporção e a verdadeira 
significação das coisas. De modo que não nos podemos jamais entender... (QUEIRÓS, $N C$, s.d, v.II, p.1412, grifo nosso).

Assim, substancialmente diferenciados, a única condição que se estabelece é a do artista que se interessa pelo protótipo apenas por ser uma "curiosidade arqueológica", um tipo para seus romances realistas. Contudo, essa depreciação sugerida por Eça a Chagas é facilmente refutada pelas considerações de Ventura no que diz respeito a controvérsias, pois, a polêmica é uma “[...] luta [que] se dá entre iguais, o combate é travado entre pares”. (VENTURA,1991.p.147, grifo nosso) Desse modo, o debate entre eles só poderia ocorrer, inicialmente, se estivessem nivelados intelectualmente.

Pinheiro Chagas não se dá por vencido e replica com inesperada e desconcertante credulidade simplista sobre a pequena ficção histórica em que Eça o retratou.

Como é admirável o seu talento e prodigiosa a sua imaginação! Que torrentes de humorismo na sua longa carta! E como eu ri a bom rir com a descrição do brigadeiro do tempo de D. Maria I! Ri deveras, desconstrangidamente, sem a mínima revolta de amorpróprio!(CHAGAS, 1880 apud MATOS,1988, p.713)

Chagas, nesse trecho, dá-nos mostras de conhecer e admirar os dotes caricaturais de seu oponente. No entanto, não deixa de soar irônico sua fala quanto ao seu amor-próprio. É certo que Chagas não demonstrava nem fraquezas nem fúria diante da ridicularização a qual estava sendo exposto. E em outra proporção, Chagas revidava buscando demonstrar a ignorância de Eça, a sua falta de crítica histórica revelada na apreciação dos acontecimentos quinhentistas.

Ainda na sua réplica, Chagas não esconde o seu descontentamento por Eça ter preterido a sua História de Portugal, optando pela de Oliveira Martins. Chagas ao citar outras personalidades do meio literário rebate o desdém de Eça com uma crítica sutil, a de 
que este tinha não só desconhecimento histórico, mas também pouco domínio quanto ao que se escrevia em Portugal.

Leu-os o Herculano coitado! E teve até a pachorra de os elogiar. Leu-os o Camilo, que os cita, freqüentemente, e você não imagina como eu folgo de ver que sou, de vez em quando, em espírito, companheiro de vigília daquele forte, brilhante, enérgico e incansável trabalhador. (CHAGAS, 1880 apud MATOS, 1988, p.713).

Neste ponto, caracteriza-se um artifício próprio da dissimulação eciana em suas controvérsias, a alegação do desconhecimento da produção literária do interlocutor. Como novamente afirma Eça na polêmica Brasil e Portugal:

[...] Porque você está ainda afurrado comigo. [...] Por eu ter ido beber as minha informações à História de Portugal do Sr. Oliveira Martins - em lugar de as ter procurado, com sofreguidão, na sua História de Portugal, na História de Portugal de Pinheiro Chagas! Eu compreendo o furor dum historiador que tem História como tabuleta e porta para a rua, ao ver o freguês ir alegremente fornecer-se de ciência à História do vizinho e do rival. [...] E o público mesmo, o público sério, constitucional e parlamentar, pode talvez estranhar que eu, tendo aqui a "História de Portugal" de Pinheiro Chagas, monumento decerto grandioso, donde salta, por torneira de ouro, o puro e forte jorro da verdade, fosse beber a História de Portugal de Oliveira Martins, fonte feita dum tijolo entre duas ervas, donde pinga espessamente a baba crassa do erro! O meu comportamento parece com efeito uma ofensa a todas as leis humanas mas vou justificá-lo ...

Meu caro Chagas, conhecendo bem as suas belas obras de teatro, de polêmica, de poesia e de crítica - eu totalmente ignorava que você fosse um historiador e tivesse escrito a História de Portugal. Sabia decerto, que você publicava estudos, fragmentos, episódios, constituindo uma interessante série de ensaios históricos; e a eles aludi quando procurei analisar a sua organização de brigadeiro. (QUEIROS, NC, s.d, V. II, p.1410, grifo nosso)

Eça consegue realçar ainda mais o cabotinismo de Chagas ao comparar a obra histórica deste por meio de palavras de forte sentido, como "jorro da verdade", e a de Oliveira Martins, "a baba crassa do erro". Apesar das ditas qualidades da obra de Chagas que, na concepção eciana, são estudos fragmentados, fica evidente o menosprezo de Eça. Pois este 
preteriu a História de Portugal de Chagas em favor da de Martins, até mesmo quando empreendeu o projeto da novelinha satírica do brigadeiro dedicado ao seu rival.

Retomando o pseudodesconhecimento de Eça pelas obras de seus oponentes, Matos (2001) cita essa ocorrência em mais dois momentos das polêmicas em que o autor de $O$ primo Basílio se envolvera, com Antônio Enes, em 1871, em As farpas e; finalmente, com Bulhão Pato, quando este foi modelo para a caracterização da personagem Alencar, em $O s$ Maias. Entretanto, este crítico expõe que a História de Portugal de Chagas obtivera tanta notoriedade que não teria sido possível desconhecê-la, principalmente num meio literário tão limitado e tão pobre de acontecimentos.

Em certo ponto do seu texto, Campos Matos (2001) explicita que uma das causas do decréscimo das obras históricas de Chagas por parte de Eça teria sido certamente a influência direta de Oliveira Martins ${ }^{83}$. Dessa maneira, para sanar quaisquer dúvidas quanto à competência dos escritos de Chagas, este crítico busca subsídios em outro estudo, o de Sérgio Campos Matos (1998). Este último salienta que a História de Portugal de Pinheiro Chagas foi parâmetro, durante muito tempo, no ensino nos liceus em Portugal, devido, certamente, a sua redação didática, a forma expressiva e original dessa obra. Salienta inclusive que essas qualidades foram determinantes para que o sucesso se estendesse até ao século XX, sendo substituída, portanto, só em 1922, pelos estudos de Fortunato de Almeida.

As histórias literárias, em destaque a de Simões (1945), são unânimes em conceituar e exaltar, nessa polêmica, que a argumentação de Eça estava voltada para a razão e crítica e a de Chagas para a eloquiência e o conformismo. Embora esse comentário, autores, como

\footnotetext{
${ }^{83}$ Cf. Campos Matos, 2001, p.347. Oliveira Martins tinha pouco apreço tanto pela pessoa de Chagas quanto pelo conjunto de sua obra, que expressiva parte estava ligada à história.
} 
Régio, nesse mesmo ano, salientam que não se pode desabonar todo o discurso de Chagas na polêmica Brasil e Portugal quanto à idéia de patriotismo, pois muitas de suas argumentações são pertinentes, apesar de seu artigo não explicitá-las.

Outro também que não partilha das idéias de Simões é Campos Matos (2001). Na sua concepção, muitas considerações de Chagas em suas cartas destinadas a essa querela são relevantes. Por exemplo, nas duas recomendações que ele faz a Eça na sua segunda réplica, e que este viria a cumprir ou pelo menos tentar efetivar esses projetos, Chagas aconselha ao seu patrício que mude a estratégia de eterno desdém pela pátria e sugere-lhe uma ação prática:

Melhor era que empregasse o seu tempo e a sua pena admirável em apropriar para uso das escolas portuguesas alguns desses magníficos livros elementares que tanto abundam em Inglaterra - tanto escasseiam em Portugal, como eu fiz por exemplo à Fisiologia das escolas, de mistress Bray. [...] (CHAGAS, 1880 apud CAMPOS, 2001, p.350)

A segunda recomendação de Chagas, de acordo com Campos Matos (2001), nessa mesma carta, consiste no sentido de criar uma revista de estudos sérios e elevados, obra mais digna do grande movimento intelectual da sua época. Com isso, Chagas terminava por exaltar o verdadeiro patriotismo dos que estudam e trabalham ${ }^{84}$ na reconstrução do Portugal decadente.

No entanto, do lado oposto à crítica de Matos, está a de Ferreira (1966) que não vislumbra nenhum argumento que se pudesse aproveitar dos textos de Chagas nesta polêmica. Ao contrário, ele destaca que a polêmica Brasil e Portugal terá resquícios ideológicos e emocionais da contenda 1865, pois permaneciam vivos dois sistemas

\footnotetext{
${ }^{84}$ Cf. Campos Matos, 2001, p. 350. Por mais estranho que pareça, em uma carta datada de 23 de julho de 1891 , dez anos depois, Eça, motivado por problemas de dinheiro, em Paris, escreve a Oliveira Martins a propor-lhe o plano de uma Biblioteca Escolar de instrução Primária a imprimir em Paris, segundo os melhores e mais novos métodos de França, Inglaterra e Alemanha. Contudo, as observações negativas de Oliveira Martins o fazem desistir desse projeto.
} 
distintos, o Ultra-romantismo tardio e o Realismo já estabelecido. E conclui que só por meio dessa contenda se poderia ver liquidadas as contas entre esses dois grupos ideologicamente distanciados, ou seja: “ [...] Será necessário esperar pachorramente pela saudável gargalhada de Eça, assistir, enfim, de alma lavada, à escalpelização crítica do patriotismo dos 'brigadeiros vestidos à moderna' ".(FERREIRA, 1966, p.106).

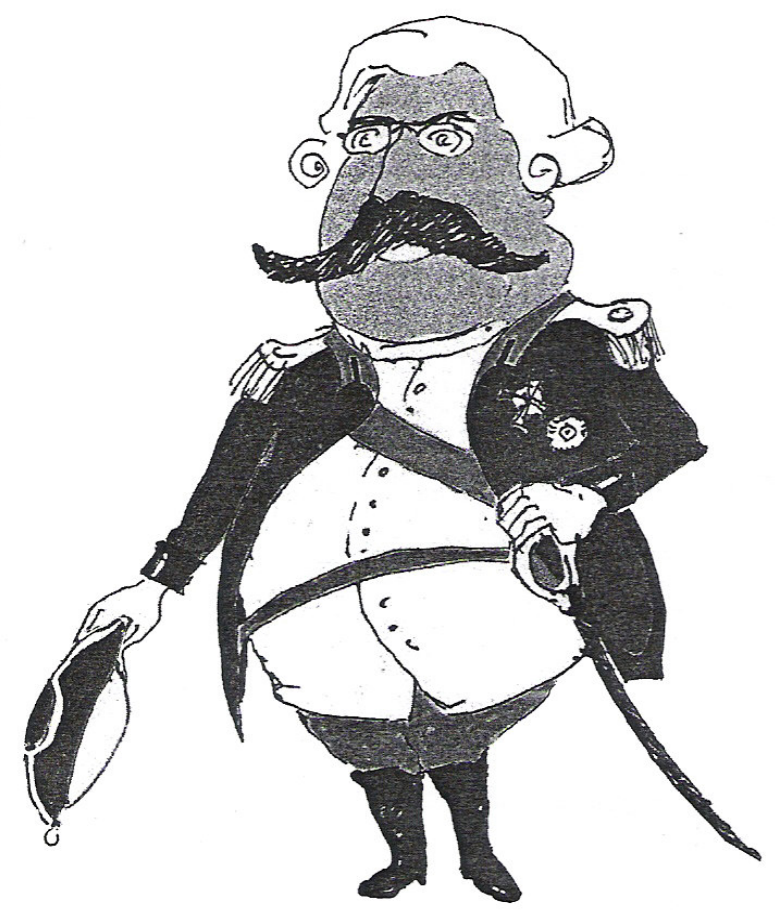

Pinheiro Chagas como "Brigadeiro de D. Maria I" Caricatura do Arquiteto Rui Campos Matos (Figura extraída de Campos Matos, 2001)

Constatamos ainda que não somente a crítica de Ferreira (1966) irá recuperar o epíteto de "brigadeiro" sarcasticamente elaborado para Chagas, outro estudioso que incorre nesse mesmo erro é João Medina (1974). No seu artigo, este crítico traça uma síntese biográfica dos envolvidos no atentado sofrido por Chagas. Presenteia o seu leitor com um contraponto 
entre a vida de Chagas - um "literato medíocre, mas festejado e premiado" que viveu entre as facilidades e glórias do seu tempo - e Louise Michel - anarquista da Comuna, que conhecera a miséria, as mazelas de uma guerrilha e, posteriormente, a derrota, a deportação e o horror do exílio. Medina (1974) não esconde a sua reprovação e escárnio à postura ideológica de Pinheiro Chagas. A única idéia plausível que se tem dessa leitura é a de que o atentado sofrido por Chagas foi uma reação legitimada por sua ação leviana e despropositada.

Como já antecipamos, a particularidade deste estudo de Medina (1974) que nos interessa, consiste no fato deste autor se referir a Pinheiro Chagas, sempre que oportuno pela alcunha criada por Eça, nessa polêmica, de "brigadeiro". Em pelo menos três vezes, num mesmo parágrafo de mais ou menos trinta linhas, o codinome "brigadeiro" aparecerá sob uma perspectiva pejorativa. Contudo, no fragmento que apresentamos, subtraímos algumas frases para que a citação não parecesse muito extensa.

Antes de passarmos ao "brigadeiro" Chagas, retenhamos este ponto psicológico: Louise Michel, a "vierge rouge", a ardente e pura vestal vermelha da Comuna e da Anarquia, é uma mulher dum "grandioso coração". Dito isso, passemos ao ministro do nosso país, arredado das grandes lutas européias, digestivo e plácido diante dum mar já sem mistério. [...] o "brigadeiro" Chagas (que deve esta cauda, presa ao seu nome por Eça, por ter seguido a carreira militar, tendo sido promovido a alferes em 1859 para pouco depois passar à disponibilidade) [...]. Aplaudiu assim o encerramento das Conferências do Cassino (1871), já deputado, já instalado no poleiro dos Abranhos e dos Acácios que governavam o País. Nesse mesmo ano iniciou uma história da Comuna de Paris onde, no dizer de Sampaio Bruno, revelava o 'seu conservantismo falsamente liberal e estrutivamente retrogradizante' e uma 'severidade nacionalista e militarista, enfática e retórica' era a expressão da 'opinião conservantista, liberal burguesa, constitucionalista e moderada', como o diz ainda Sampaio Bruno. Outro depoimento, este de Ramalho, em 1895, ano da morte do "brigadeiro"[...]. (MEDINA, 1974, p.18, grifo nosso) 
Para esclarecimentos, ressaltamos que a maior patente que Pinheiro Chagas obteve foi a de capitão, em 1888. Nas palavras de João Medina, nesse mesmo texto, esta titulação de "brigadeiro" foi um rompante da generosidade de Eça de Queirós, que promoveu Chagas ao mais alto cargo. Isso nos faz acreditar que de certa forma este crítico recupera toda a carga semântica depreciativa que Eça caracterizou a personagem Chagas na sua pequena ficção dentro do texto da polêmica Brasil e Portugal.

Embora isso, tempos depois, Medina (2001) traz à luz novamente esse estudo, só que de forma sucinta, sobre o atentado anarquista sofrido por Chagas ${ }^{85}$, compilado em sua obra, Eça, Antero e Vitor Hugo ${ }^{86}$. Outra vez, Medina esboça um contraponto entre as posturas dos dois, Louise e Chagas, enquanto vítimas de atentados. A primeira, exemplo de abnegação e perdão, engaja-se até mesmo na defesa do seu agressor. O segundo, perfeito em seu egoísmo, tende a se prostrar ainda mais de vítima para assim comover excessivamente uma nação. De certo modo, a única mudança existente entre os textos de 1974 e 2001 está na supressão da referência pejorativa de "brigadeiro" na citação a Chagas. Contudo, Medina ainda dispensa a este autor sua reprovação quanto ao episódio em que Chagas se colocara contrário à idéia socialista da Comuna, na pessoa de Louise Michel. O interessante é que Medina (2001, p.110), em seu texto, não perde a oportunidade em relacionar o autor de A mantilha de Beatriz não somente como inimigo da causa francesa, mas também como “[...] o eterno zoilo da geração de 70 [...]”.

\footnotetext{
${ }^{85}$ Ver. Medina, 2001. pp-109-114. Realmente, o texto parcial da carta de Chagas citado neste estudo apresenta um tom zombeteiro, irônico e depreciativo contra a figura de Louise Michel. Nele, Chagas é extremamente machista e tenta desconsiderar a força política e revolucionária dessa anarquista que levantou a bandeira do socialismo. Depois da publicação desse artigo, Louise Michel declara, segundo Medina, que preferiria antes aqueles que disparassem sobre ela aos que a insultavam à distancia.

${ }^{86} \mathrm{O}$ capítulo de nosso interesse intitula-se Para História do anarquismo em Portugal: o atentado contra Pinheiro Chagas.
} 
Outro estudo de referência que exclui Chagas do cânone português e o imortaliza pejorativamente como uma "figura grotesca dos Brigadeiros Chagas" é o autor do Labirinto da saudade. Lourenço (1982) considera que Eça destruiu com genialidade a demagogia patriota dos seus adversários, ao confrontar a degradação do patriotismo (partido de Chagas) versus a preocupação sobre o destino nacional sob o "estatuto da desconfiança". (partido da Geração de 70).

[...] Eça de Queirós, através da sua obra, ou a meias com Ramalho Ortigão nas Farpas, sem falar nas célebres variações sobre as várias formas de pseudopatriotismo - desde o patrioterismo aos patriotarrecas plantadas nas figuras grotescas dos Brigadeiros Chagas, Pacheco e outros Acácios, acabou por lhe assestar semanticamente o golpe de morte. (LOURENÇO, 1982, p.95)

A alcunha de "brigadeiro" é uma síntese do olhar redutor e simplista não só das críticas que explicitamos nos fragmentos acima, em relação a esse fato, mas temos ainda, as de Lisboa (s.d), Simões (1980), Machado (1996). Sendo que as idéias contidas nesses textos constroem um escritor de "patriotismo ultra-romântico" e "curiosidade arqueológica". Outra abstração eciana retirada de seus textos polêmicos e recuperada pela crítica é o fato de Chagas ter tido o propósito de intrigá-lo com Portugal. Dentre os estudos do século passado que recuperaram tal informação, podemos citar pelo menos o de Vianna Moog (1938), Lins (1939) e o de Figueiredo (1940).

Aproximando do término dos embates, Campos Matos (2001) expõe ainda que Pinheiro Chagas voltará pela última vez à liça, nas páginas d' $O$ atlântico, no dia 13 de fevereiro de 1881 , depois de se referir a Eça de Mandarim ${ }^{87}$. No entanto, Chagas concorda com Eça no que se refere à educação dos portugueses no século XVI. Na concepção dele

\footnotetext{
${ }^{87}$ Por alusão à obra com esse título que Eça publicara pouco antes da contenda Brasil e Portugal.
} 
trata-se de uma educação ultra-religiosa que vincula ao espírito português sentimentos de fanatismos e intolerância.

Acabadas as réplicas de ambos os lados, continuam muitas divergências, uma dessas concerne na afirmação de Eça sobre a Renascença, que em sua concepção era um mundo de humanidade e de simpatia universal. Chagas rejubila, acusando-o de ter uma idéia da Renascença como trovadoresca e lírica. Cita-lhe depois copiosamente toda a violência dessa época, aconselhando-o a ler as Memórias de Benevenuto Cellini. Segundo Campos Matos (1988, p.713), o autor da História de Portugal terminará a sua réplica expressando em termos de grande engenho e elegância: "E já se vê que, apesar da enorme distância que nos separa, damos ambos simultaneamente uma prova de bom critério literário, eu lendo os seus livros, você não lendo os meus".

Não queremos aqui, eximir os excessos de Chagas nos confrontos polêmicos que teve com Eça e as possíveis repercussões negativas que possa ter sofrido este na sua época. Entretanto, as palavras de Simões (1945), Ferreira (1966), Medina (1974), Lourenço (1982), só corroboram mais com as nossas conjecturas sobre a postura de algumas histórias literárias que não conseguem deixar de reproduzir e espalhar a fala de outros, sem que se estabeleça uma parcialidade de julgamento. Talvez seja interessante agora, recorrermos a Régio (1942 apud Lisboa s.d), quando este explicita que o lugar comum dessas histórias está muito relacionado à unanimidade crítica em considerar todo o século XIX senão Eça ou por meio dele. Sem nos esquecermos de que nas histórias literárias a exaltação de um artista só é válida à custa de diminuir outros. 
2.2.

\section{A relíquia, um embate literário.}

Em junho de 1887, o Diário do governo abre o concurso para a atribuição de um prêmio literário a cargo da Academia Real das Ciências. Eça concorre a esse com $A$ relíquia e Pinheiro Chagas será o relator do parecer do prêmio, que saiu em 11 de dezembro de 1887. A relíquia é preterida, ganhando o drama de Henrique Lopes de Mendonça, $O$ duque de Viseu. Nesse relatório, Chagas, inicialmente, critica o regulamento do prêmio que permite o concurso de obras de gêneros diferentes. Em seguida, passa em uma análise rápida por obras de pouco conhecimento do público, para posteriormente analisar com mais afinco A relíquia Eça de Queirós ${ }^{88}$. Não deixa, entretanto, de o elogiar e o comparar às maiores figuras literárias do cânone.

Essa polêmica não tem tanto destaque como a de Brasil e Portugal nas histórias literárias, talvez porque, mesmo diante das arbitrariedades do regulamento do concurso, as censuras de Chagas quanto à Relíquia fossem coerentes e sensíveis, caracterizando a vacuidade de Eça. Alguns biógrafos de Eça, como Lins (1939) acrescenta-nos que das polêmicas travadas pelo autor de Os Maias, esta "[...] é a mais frágil e a mais ausente de sentido. [Eça] Desliza pelo assunto, divaga em torno de outros, perde-se sobre vagas considerações a respeito do papel das academias e não responde nada. [...]" (LINS,1939, p.133).

Acreditamos que essa polêmica, novamente, traz em si vestígios da luta pelo poder intelectual no cenário português, dois representantes ideologicamente distanciados por suas

\footnotetext{
${ }^{88}$ Ver Carvalho ,1890,p.303-304. De acordo com essa autora, Pinheiro Chagas prioriza em seu Relatório poucas linhas até mesmo para o vencedor do prêmio, $O$ duque de Viseu de Henrique Lopes de Mendonça.
} 
concepções literárias. Essa controvérsia surgida após o Relatório de Pinheiro Chagas ${ }^{89}$ ilustra a turbulência que passava ainda o meio literário em Portugal em 1888. Mesmo depois das Conferências do Cassino, em 1871 - que para muitos estudiosos foi advento do Realismo em Portugal - ainda conviviam nesse campo dois tipos de tendências literárias, uns que se ligavam ao Realismo e outros que se mantinham contrários a ele. Nesse último grupo, perfilavam Pinheiro Chagas e outros escritores que, para alguns da imprensa da época, faziam parte da chamada literatura oficial. Na teoria de Carlos Reis (2001), esse tipo de literatura consistia na consolidação de um grupo de homens de letras que estavam de alguma forma ligados ao poder e às instituições da Regeneração. Como podemos ver pelo prólogo que antecede a carta de Eça de Queirós a Mariano Pina, sobre o Relatório de Pinheiro Chagas, publicada n' A Ilustração ${ }^{90}$.

Os nossos leitores ainda não esqueceram a vigorosa campanha sustentada em janeiro último, nas colunas da Ilustração, pelo nosso diretor Mariano Pina, em que ficou preterido o nosso grande romancista Eça de Queirós. [...] A crônica de Mariano Pina causou verdadeira sensação tanto em Portugal, como no Brasil, donde o nosso diretor recebeu inúmeras cartas de felicitação e de aplauso; - ao mesmo tempo que causava verdadeiro escândalo entre a literatura oficial do nosso país.(ILUSTRAÇÃ̃, 1888, p.150)

Eça também não deixa por menos e cita sutilmente esse tipo de literatura, em seu texto A academia e a literatura ${ }^{91}$, de forma textualmente irônica:

\footnotetext{
${ }^{89}$ Ver Neves, 1919 apud Amaral, 1947, p.281-287. Segundo Neves, o Relatório de Chagas, perdido no jornalismo da época, foi editado pela Academia em folheto, hoje raríssimo. No seu texto, Álvaro Neves transcreve somente os pareceres de Chagas sobre a Relíquia, como forma de ilustrar o porquê da desconsideração da Academia quanto à obra eciana. Para esse crítico, o parecer de Chagas é a representação de uma crítica coerente e esmerada, assim conclui: "Aqui ficam notas documentais para a biografia do notável crítico da sociedade portuguesa no século XIX, Vencido da Vida, e vencedor na perfectibilidade suprema da sua obra requintadamente artística."

${ }^{90}$ Mariano Pina era proprietário e diretor d' A Ilustração, como também grande amigo de Eça de Queirós.

${ }^{91}$ Esta carta é datada de 25.01.1888, fora retida, pois Pinheiro Chagas acabara de ser alvo de um atentado cometido à bengalada por um anarquista, que quase o vitima. Isso resultado de um artigo onde Chagas usa termos depreciativos e ofensivos a Louise Michel, heroína socialista da Comuna de Paris. Dessa forma, só em 20 de maio de 1888, essa carta foi transcrita na revista A Ilustração.
} 
[...] Pinheiro Chagas naquela ruidosa e valorosa azáfama que o traz redemoinhando com tanto brilho da política à literatura, confunde a Academia com o parlamento, toma-me estonteadamente por um ministro da Fazenda, e investe contra mim por causa da questão dos tabacos!(QUEIRÓS, $N C$, s.d, v. II, v.2, p.1460).

Mesmo depois de estabelecido o Realismo, com as Conferências do Cassino, em Portugal, parece-nos que o grupo de Pinheiro Chagas, que era caracterizado ainda como literatura oficial, permanecia como um incômodo e uma ameaça constante ao grupo de Eça. Para este, a cotérie ${ }^{92}$ de Chagas estava diretamente ligada à Academia, assim, podia ocupar posições chaves e distribuir vantagens e favores.

Na revista A Ilustração (1888) diante de cada artigo dessa polêmica tem um preâmbulo para orientar o leitor sobre a última réplica, tentando levantar algumas considerações sobre o embate literário. Ao nosso ver, não deixa de ter uma certa inclinação para um dos debatedores, pois se trata de posicionamentos e, diante disso, algum lado teria de ser preterido. Aqui, particularmente, A Ilustração, ao final de toda querela, posiciona-se favorável às idéias defendidas por Eça de Queirós e Mariano Pina. Como transcrevemos na íntegra o trecho publicado antes do último texto de Eça, Ainda sobre a Academia.

Hoje publicamos a resposta de Eça de Queirós, a esse artigo do ilustre relator tão famoso quão discutido concurso. E sem todavia queremos sair da imparcialidade que nos impuséssemos, reunindo todos os documentos desta pendência provocada pela crônica do nosso diretor, quando teve lugar o concurso - não podemos deixar de declarar que a pendência deve terminar aqui, porque é impossível chegar-se a um acordo. - Mariano Pina afirma que tudo foi feito com a maior irregularidade: programa do concurso, composição do júri; e votação em que tomaram parte, sócios efetivos e correspondentes... Pinheiro Chagas afirma que tudo se fez regularmente e que o voto foi justíssimo. - Eça de Queirós põe a questão neste terrível estado: que um júri literário, seja ele qual for, não pode num concurso dizer o que é melhor se um livro de história, se um poema, atendendo a que são gêneros totalmente opostos.... E de tudo isto, o que

\footnotetext{
${ }^{92}$ Cf. Neto, 1973, p.126. Nessas igrejinhas literárias ou cotéries é constante a excessividade de elogios mútuos dentro do grupo, e fora dele os ataques desproporcionais aos rivais.
} 
concluímos nós, o que conclui a galeria, o que conclui o público?... Que no primeiro concurso houve irregularidades e faltas de previdências imperdoáveis. Que o programa era detestável, porque admitia todos os gêneros literários, o que é um absurdo, e torna o voto impossível. E que de futuro a Academia deve organizar um melhor programa, um júri mais literário, e uma votação mais acadêmica, aliás - os conflitos hão de recomeçar todos os anos. (ILUSTRAÇÃO, 1888, p.215).

Partindo dessa proposição, antes de recapitularmos as investidas dos interlocutores nesta contenda, apresentaremos algumas idéias do Relatório de Chagas para estabelecermos ao final, quem sabe, esclarecimentos sobre as causas que motivaram esse novo embate entre Pinheiro Chagas e Eça de Queirós.

Como já antecipamos, no início do Relatório, Chagas tece elogios à grandeza literária de Eça, não deixando com isso de reforçar o seu repúdio quanto aos princípios realistas, que, para ele, são meras descrições gongóricas. Chagas elege um tipo de literatura em que a arte seja o espelho da sociedade, não no sentido da descrição minuciosa da matéria, mas como meio do leitor se rever no romance. Isto é, a ficção poderá ser uma oportunidade de aprofundarmos no conhecimento de nós mesmos.

[...] Bem sei que me objetam que o romance dever ser a pintura da sociedade real, e não de uma sociedade fictícia que nada se lucra com a leitura de um livro onde não aprendamos a conhecer os homens, e onde pelo contrário sejamos levados a encará-los por um prisma enganador. [...] neste século, em que vai sendo cada vez mais pronunciada a tendência materialista, onde se poderão refugiar as nobres aspirações da humanidade, se o santuário da literatura também for profanado, se lhe arrancarem de lá a estátua do ideal para arrastarem pelo tremendais da sociedade, [...]. (CHAGAS, 1866, p.10)

Esse princípio é ainda bem caracterizado pela seguinte frase do crítico: “[...] Dize-me o que lês, dir-te hei que manhãs tens" (CHAGAS,1867,p.266).

Acreditamos que, outra vez, apresentam-se nessa contenda os temas que já foram motivos de discórdia entre Pinheiro Chagas e Eça de Queirós, como por exemplo, o 
Realismo e a questão histórica, só que esta última agora, no sentido da história ficcionalizada. Dessa maneira, faz-se necessário explicitarmos em que se baseiam nossas conjecturas. Para tanto, iremos nos servir do seguinte fragmento da réplica de Eça, que nos diz nestes termos: “ [...] O que indigna Pinheiro Chagas, o que ele designa a Academia como imperdoável, é ter Teodorico visto a Paixão na sua comovente possibilidade histórica - em lugar de a ter visto, como ele textualmente escreve, sob as formas dum Evangelho burlesco! (QUEIROS, s.d, NC, v.II, p.1459, grifo do autor)". Nesse trecho, ao nosso ver, temos duas preposições indissociáveis que são censuradas por Chagas; a primeira e principal, no que se refere à incoerência do narrador em primeira pessoa, quanto à descrição da passagem histórica do livro, o sonho de Teodorico, que por seu lado, configura-se na falta de unidade lógica da construção da personagem.

Por meio dessa definição de Chagas, não há uma unidade lógica nessa narrativa eciana quando seu autor coloca na fala de Teodorico o seu nível de conhecimento histórico, já que Raposão era um tipo caricato, um anti-herói. Se na questão Brasil e Portugal, para Chagas, Eça pecou pela falta de autoridade histórica, aqui ele se condena pelo excesso. Em outros termos, o autor do Poema da mocidade considera que Eça:

Imaginou, [...], que seria original e estranho fazer contemplar e descrever a paixão de Cristo por um pateta moderno, um devasso reles, vicioso e beato, mantido por uma tia no culto piegas de Nossa Senhora da Conceição e no sagrado horror das saias, e fazendo às furtadelas as suas incursões pelo campo do amor barato, e do cigarro e da genebra à mesa do botequim. Este homem transportado fantasticamente para Jerusalém do tempo de Cristo, vendo e descrevendo o grande drama sagrado, devia dar ao mundo um Evangelho burlesco, ímpio de certo, muito mais escandaloso que as Memórias de Judas, mas que podia ser, em todo o caso, uma obra de arte notável." (CHAGAS, 1887 apud AMARAL; MARTHA, 1947, p.285) 
Chagas entendia que existia a convivência de dois Raposões inconcebíveis. O lógico era que o Raposão, um ateu atrevido, narrasse uma paródia do evangelho.

Acontece, porém, que o autor parece ter feito à parte o seu romance da Paixão de Cristo, colocando-o depois à pressa nas páginas do outro. Quem adormece é Teodorico e quem sonha é o autor, e com grande surpresa nossa, vemos aquele adorador de santinhos e frequientador das ruas suspeitas de Lisboa sonhando que vê a Paixão de Cristo em todo o seu grandioso aspecto histórico. [...].Voltando à realidade com as impressões do sonho, aquele burguês devasso e tolo sente a sua alma inundada de uma luz nova? [...] Nada disso. Teodorico volta a ser o que fora, a sua transformação no final do romance em nada modifica a sua fisionomia burlesca. Singular equívoco foi este, e que nos faz supor que o Sr. Eça de Queirós não quis sacrificar o trabalho já feito com intuitos diversos para refazer a grande cena histórica já por ele traçada, colocando-a no foco da luneta de Teodorico. [...] Se Eça de Queirós recuava diante da profanação de corrigir o drama do Evangelho com a equação pessoal do seu Teodorico, para que inventou este personagem e o colocou em situação de presenciar tão grandiosas cenas? [...] Teodorico se mostra apta para compreender o que há de grandioso e de sublime no drama de Cristo? Eis o defeito irremediável do livro [...].CHAGAS, 1887 apud AMARAL; MARTHA, 1947, p.285-86, grifo nosso)

Seguindo essa perspectiva, Chagas conclui “[...] logo que o leitor se esqueça de quem é o personagem quem sonha, é uma beleza verdadeiramente admirável” (CHAGAS, 1887 apud AMARAL; MARTHA, 1947, p.286). Contudo, o relator de A relíquia ressalta que um dos trechos mais brilhantes desse livro é a transição da realidade para o sonho, elogiando a capacidade do autor de $A$ relíquia em criar um cenário profundamente sensorial que nos transporta ao mundo onírico.

A respeito dessa mesma análise crítica, mereceria referência o fato de Pina, segundo Simões (1945), fazer as mesmas advertências quanto às incoerências ficcionais n' $A$ relíquia. Mariano Pina, como também apontou Pinheiro Chagas, considera incongruente o quadro histórico da Paixão de Cristo dessa obra em relação à mediocridade do Teodorico

\section{Raposo.}


Se $A$ relíquia fosse um romance, nós ficaríamos hesitantes sem saber qual o fim do livro: se os efeitos convergem unicamente para o quadro histórico da Paixão de Cristo - ou se convergem unicamente, como seria de todo o ponto racional, para a completa pintura desse tipo notável, dessa figura típica duma sociedade, e que no livro se chama Teodorico Raposo. [...] Abordaremos francamente o defeito artístico de A relíquia, defeito que, felizmente, o autor pode corrigir numa segunda edição, com a mesma facilidade com que o escultor pode, no mármore, corrigir a deformidade dum músculo que o artista errou no gesso. É a questão do eu, o ser o livro a conversa na primeira pessoa dum personagem bastante mediocre e bastante ignorante, recebendo durante a sua viagem de Lisboa a Jerusalém impressões e sensações como só as recebe um espírito superior, e vendo aspectos e indivíduos através dum prisma como só pode possuir e manobrar um artista maravilhosamente dotado, como é o Sr. Eça de Queirós. (PINA, s.d, apud SIMÕES, 1945, p.546547, grifo nosso)

No entanto, no texto A academia e a literatura, Eça irá explorar a fundo essa afirmação de Chagas, com habitual humor, criticando o ponto de vista deste:

O fato é, caro Pina, que Pinheiro Chagas no seu Relatório não dá, com indizível assombro meu, as razões honrosas e altas. Antes pelo contrário! Apresenta, para repelir A relíquia, razões estranhamente comezinhas e miudinhas, rasteiras e grosseiras, como se, em lugar de falar numa Academia, se achasse conversando num botequim diante de homens incultos, incapazes de compreender tudo o que é elevado ou profundo! [...] O que aponta ele à reprovação da Academia? O sonho de Teodorico - esse sonho em que o obsceno homem presencia aquilo que Pinheiro Chagas reverentemente chama "as grandiosas cenas da Paixão". [...] Porventura o desgosta, como acadêmico, a falta de sobriedade, de harmonia, de proporção, de purismo? - Não! Acha tudo perfeito. O que indigna Pinheiro Chagas, o que ele designa a Academia como imperdoável, é ter Teodorico visto a Paixão na sua comovente possibilidade histórica - em lugar de a ter visto, como ele textualmente escreve, "sob as formas dum Evangelho burlesco!" Quer dizer: - para que $A$ relíquia agradasse a Pinheiro Chagas e merecesse a coroinha da Academia, eu deveria ter mostrado Jesus de Chapéu de coco e lunetas defumadas, Pilatos deixando cair o pingo de rapé sobre o Diário de Notícias, e ao lado Oseias, vogal do Sanedrim, numa fardeta de polícia civil, com um número na gola, escabichando um dente furado. (QUEIRÓS, $N C$, s.d, v.II, p.1459, grifo nosso) 
Curiosamente, Eça comenta sobre essa fragilidade em $A$ relíquia ${ }^{93}$, pelo menos duas vezes oficialmente. Na primeira ocasião, de forma mais evidente, em carta ao seu amigo Luis de Magalhães, pouco tempo depois de aberto o concurso, e antes de sair o relatório de Chagas. A outra em resposta ao relatório final do concurso da Academia, carta endereçada a Mariano Pina, intitulada $A$ academia e a literatura. Ressaltado isso, voltemos, agora, nossa atenção às reflexões que Eça fez a estrutura da sua obra aos amigos, respectivamente:

Eu por mim, salvo o respeito que lhes é devido, não admiro pessoalmente A relíquia. A estrutura e composição do livro são muito defeituosas. Aquele mundo antigo está ali como um trambolho, e só é antigo por fora, nas exterioridades, nas vestes e nos edifícios. É no fundo uma paráfrase tímida do Evangelho de S. João, com cenários e fatos de teatro; e falta-lhe ser atravessado por um sopro naturalista de ironia forte, que daria unidade ao livro. D. Raposo, em lugar de se deixar assombrar pela solenidade histórica, devia rir-se dos judeus e troçar dos Rabis. O único valor do livreco está no realismo fantasista da Farsa. (QUEIRÓS, CO, s.d, V.III, p.575, grifo do autor).

A relíquia é certamente um livro malfeito ${ }^{94}$. As suas proporções faltam harmonia, elegância e solidez; certos personagens, apenas recortados e não modelados, oferecem uma notação uniforme e esfumada; a forma não tem suficiente fluidez e ductilidade, antes por vezes encaroça e empasta e por querer ser grave parece hirta como sucede aos grandes homens da província, etc... etc... Mas estes defeitos, que só podem ser sentidos por um gosto afinado na perene convivência das coisas de Arte, nunca poderiam provocar a condenação dum livro numa Academia que não está povoada de artistas. (QUEIRÓS, NC, s.d, v.II, p.1456-1457, grifo nosso.)

Podemos ver nesses trechos que a origem da polêmica quanto à réplica de Eça parece

não estar nas imperfeições da estrutura de sua obra, mas sim no fato de ela ter sido desmerecida por pessoas que, para ele, não têm autoridade literária necessária.

Na sua carta a Mariano Pina, A academia e a literatura, Eça também ressalta a falta de critério desse concurso, como discutira Pinheiro Chagas em seu relatório. Já nos

\footnotetext{
${ }^{93}$ Cf.Campos Matos 1988, p. 714 - Diferentemente de Eça, A relíquia parece continuar a ser para muitos, fora dos países de língua portuguesa, o trabalho mais original desse autor e o que maior número de traduções tem obtido.

${ }^{94}$ Ver Régio (1945 apud Lisboa s.d, p.134) Mais uma vez, Eça de Queirós se mostrava extraordinariamente brilhante na crítica a uma obra sua, ele que algumas vezes se mostrou superficial na crítica a obras alheias.
} 
referimos a uma das estratégias utilizadas pelo Eça polemista que é o fato de sempre desconhecer a literatura de seus adversários ${ }^{95}$, como se pode abstrair deste fragmento.

Eu não conheço, muito infelizmente para mim, nenhuma das obras oferecidas a concurso e mais detidamente louvadas pelo Relatório. Bastame, porém, saber que havia um livro de viagens, um livro de odes, um drama em verso e um romance arqueológico, para desde logo pensar que qualquer preferência, entre obras tão heterogêneas e tão insusceptíveis de comparação, nunca poderá ser determinada por motivos puramente literários e críticos. E, para a Academia permanecer na equidade, forçoso lhe seria decidir - não pelas qualidades dos escritos, mas pelas qualidades dos escritores, todos homens, todos cidadãos, todos mortais, e todos comparáveis, já no seu peso em quilos, já na sua pontualidade à missa, já no asseio da sua roupa branca. (QUEIRÓS, NC, s.d, v.II, p.1461, grifo nosso)

Assinalamos ainda, nesse trecho, que Eça sugere debochadamente que as regras do concurso, longe de serem literária e crítica, tendiam a favorecer a escritores que rezassem na mesma cartilha da Academia, na qual ele e não sua obra fora preterido. Tipicamente, caracteriza-se aqui o retorno da problemática da Questão coimbrã (1865), só que em proporções menores. Eça e Mariano Pina, em certa medida, tentam denunciar a parcialidade da Academia e os obscuros critérios de apadrinhamento a seus aliados, nesse caso o vencedor do concurso, Lopes de Mendonça. Essa polêmica, portanto, reflete a constante tensão entre dois grupos de mentalidades literárias que se chocavam. Eça, entre outras palavras, deixa claro que na Academia havia se estabelecido a política do elogio mútuo.

No entanto, Pinheiro Chagas irá retrucar a essa acusação:

[...] por mais que eu tivesse manifestado no meu relatório o meu sincero e antigo entusiasmo pelo talento de Eça de Queirós, nada havia que resgatasse aos seus olhos a culpa de não ter considerado $A$ relíquia, no seu conjunto, uma das suas obras-primas. Mas o que eu não esperava, devo confessá-lo, era que Eça de Queirós atacasse não só o relatório, mas

\footnotetext{
${ }^{95}$ Ver Campos Matos, 2001, p.347-349
} 
muito principalmente a Academia e o programa do concurso. E não o esperava por uma razão muito simples, porque para atacar a Academia e para atacar o programa do concurso eram indispensável duas coisas: não ser acadêmico e não ter ido ao concurso. (CHAGAS, 1888, p.198)

Na observação de Campos Matos (1988), Chagas não deixa de dispensar elogios ao seu confrade, no entanto, ressalva novamente que dentre as suas criações primorosas não se enquadra $A$ relíquia. Para o relator do parecer, proclamar incompetência do júri depois de um resultado desfavorável seria manifestar publicamente não uma convicção, mas a inveja e a presunção. Eça contra-ataca ${ }^{96}$ :

Suponhamos, portanto, que eu berro por despeito - e que toda a face se me acende de rancor e inveja. Pois bem! Neste vil estado de alma, que enjoaria Marco Aurélio, eu fiz uma afirmação: - afirmei que Pinheiro Chagas não podia, como crítico e criticamente, comparar para um fim de escolha e de prêmio, um romance arqueológico em prosa e um drama romântico em verso. Lívido e roído pelas cobras verdes do ciúme, eu estabeleci esta tese. Mas desde que a estabeleci por escrito, num jornal ela fica separada da minha personalidade, torna-se impessoal e abstrata, vivendo só por si e pela razão que em si contém. (QUEIRÓS, CIFM, s.d, v. III, p.921, grifo nosso)

Nesse trecho, Eça ao se defender de uma acusação de Chagas, quanto ao desmerecimento que aquele teria feito ao escritor Henrique Lopes de Mendonça - ganhador do concurso - inverte estrategicamente os papéis de caluniador e caluniado. Isso vai de encontro a uma proposição feita por Viana Moog (1938) e, posteriormente, citada por outros, como Álvaro Lins (1939), ao sugerir que:

Tornou-se impossível pensar em Pinheiro Chagas sem associar ao seu nome à idéia do ridículo. É estranho, portanto, que Eça não tenha respondido um argumento tão pobre. Perturbou-se tanto que cometeu contra Pinheiro Chagas a sua única deslealdade literária, uma daquelas deslealdades em que Camilo era mestre: modificar o sentido do

\footnotetext{
${ }^{96}$ Carta publicada n' O repórter de 2 de julho, com o título Ainda sobre a academia. Recolhida posteriormente em Cartas inéditas de Fradique Mendes e mais páginas esquecidas.
} 
argumento, criar um argumento novo e investir então contra o "fantasma". (LINS, 1939, p.134)

Por outro lado, ainda no século XX, a crítica de Simões (s.d) dá a mão à palmatória ao considerar inteligente algumas proposições do relatório de Pinheiro Chagas sobre $A$ relíquia. Para ele, esse romance torna-se o pomo de discórdia entre o romancista e a crítica oficial - a crítica oriunda do território romântico que Eça começara a hostilizar. No entanto, pela primeira vez os juízos dessa crítica não estavam inteiramente errados.

Diga-se o que se disser de Pinheiro Chagas como crítico ostensivamente detrator da personalidade e da obra queirosiana, há que lhe prestar (sic) homenagem pela lucidez com que, no seu "brilhante relatório", analisava certos aspectos menos felizes de $A$ relíquia. [...] O certo é que seria esta a primeira e única vez em que o "homem fatal" contestava ao grande romancista algo de realmente contestável. (SIMÕES, s.d, p.132-138, grifo nosso).

Contudo, Simões (s.d), em seu texto, não deixa de utilizar os termos pejorativos criados por Eça ao se referir a Chagas, como indicamos no fragmento. Para aquele crítico, apesar da coerência de algumas discussões no relatório de Chagas, este não deixa de atacar e fazer algumas censuras à obra e à personalidade de Eça. O que, infelizmente, pelo trecho acima não podemos visualizar.

Por outro lado, José Régio (1945, apud Lisboa, s.d), sinaliza que os textos polêmicos de Eça não evidenciam o exercício de uma inteligência crítica. Pelo contrário, o excessivo recurso da comicidade, estrategicamente, ajuda a ocultar a ausência de argumentação. Por isso, a presença constante de humor não faz mais do que transparecer um caráter sofístico e vago neste artigo, ao invés de uma exposição de raciocínios claros e coerentes. Um trecho típico, para Régio, trata-se do momento quando Eça retoma o problema que Pinheiro Chagas encontrou na sua obra. 
Mas, ao mesmo tempo, Pinheiro Chagas sente que esses homens, ainda que toscos, devem ter um resto de confuso e supersticioso respeito pela religião desse Jesus, dentro da qual a sua vida foi moldada. E, muito sagazmente, no seu esforço de atrair a desaprovação sobre o livro, apela também para esse sentimento. Mas como? Acusando alguma brutal negação do que é dogma, ou alguma atrevida simplificação do que é mistério? Não. Tudo isso Pinheiro Chagas o julga muito complicado para essas inteligências subalternas. E aponta então o detalhe comezinho e rasteiro, o detalhe que aqueles homens broncos mais facilmente poderiam apreciar - o cigarro que Teodorico acende no Pretório. Com a mão trêmula, Pinheiro Chagas mostra o cigarro blasfemo. E exclama textualmente: - Arrepia, arrepia na verdade ver aquele cigarro no meio de tão sublime agitação!

Portanto, em resumo, o que revolta Pinheiro Chagas neste infeliz livro é que nele Jesus de Galiléia não aparece suficientemente burlesco, e que nele Teodorico Raposo não aparece suficientemente sério.(QUEIRÓS, $N C$, s.d, v.II, p.1459-1460)

Régio sugere que Eça tinha consciência da deficiência do livro e dos argumentos coerentes do Relatório. Para este crítico, Eça partia de premissas falsas acerca da opinião de Chagas com o intuito de desorientar o leitor, e assim preparar o terreno para as suas ironias em vez de argumentação. Por fim, Régio conclui que:

Eça faz com maestria, na maioria de suas polêmicas, é tão somente tentar vencer o contraditor não pela justeza, sagacidade, firmeza, lealdade do raciocínio e da análise, - mas sim pelas graças do talento literário e o prestígio do trocista que diverte o auditório; que melhor o diverte.[...]. (RÉGIO, 1945 apud LISBOA, s.d, p.133)

Também na tréplica, Eça não esconde seu enfado, logo no início desse artigo, intitulado Ainda sobre a academia, justifica-se não encontrar nenhuma questão no texto de seu adversário que merecesse alguma consideração sua. Os supostos defeitos do relatório da Academia passa ao segundo plano da exposição de Eça que, sob esse pretexto, passa a atacar jocosamente a personalidade literária e pública de Pinheiro Chagas. Primeiramente, aquele constrói pequenas histórias, cheias de comicidade, dentro deste texto, que irão contribuir para a ridicularização de seu adversário. Não devemos nos esquecer de que essa 
peculiaridade eciana já se apresentou com maestria na contenda Brasil e Portugal. Para nós, esse trecho é um dos mais emblemáticos e, possivelmente, seja, juntamente com outros, a origem da cristalização caricata de Pinheiro Chagas. Aqui, evidenciando o perfil de escritor e crítico medíocre no seu tempo.

Somente, tratando-se de Pinheiro Chagas, o caso é radicalmente diferente. Ele é o mais honesto dos homens. Nunca da sua pena saiu voluntariamente uma falsidade ou uma perfídia. Reto, bom, amável, generoso, leal, largo de coração, ele senta-se candidamente à banca, toma a pena - para afirmar apenas o que é verídico e defender apenas o que é justo. Não sei se a pena de Pinheiro Chagas é de pato ou de aço: em todo o caso deve ter, como todas, uma haste ligeira que ele ao princípio sustenta e domina entre os dedos. A vela arde e o ilustre escritor começa a escrever... E eis que, instantes depois, aquela curta haste, conduzida pela mão já excitada, sob os impulsos impacientes da imaginação que aqueceu - larga, abala, corre, galga, pula, cabriola, redemoinha, mais tonta e levantando mais o pó que um potro bravo do Hejaz solto no deserto. Já Pinheiro Chagas a não poder sopear. De fato, já o nosso desditoso amigo vai arrastado por ela, como Mazeppa ${ }^{97}$ pelo seu corcel - e foge, rompe, fende, salta aqui as balizas da cortesia, atropela além a nudez da verdade, tudo escangalha e tudo espezinha até que escritor e pena rolam no pó, exaustos, arquejantes, inúteis para tudo e irresponsáveis por tudo!

Pinheiro Chagas é o Mazeppa do folhetim - um Mazeppa de chapéu alto. Com a diferença, porém, de que Mazeppa se ergueu ao fim da fabulosa carreira, para encontrar em torno de si uma horda bárbara que o aclamava rei! E Pinheiro Chagas, quando se levanta, acha-se rodeado de amigos que apenas sorriem e lhe gritam com uma repreensão cheia de carinho: "- Oh! Homem, quando há de você ter juízo?" E ele próprio, limpando o suor, e olhando para trás, para as conveniências que transpôs, para a verdade que pisou, suspira, com aquela sua honestidade que é tão alta e aquela sua inteligência que é tão clara, e, descontente de si, recolhe desconsoladamente a pena. Depois, no dia seguinte, recomeça. (QUEIRÓS, CIFM, s.d., v.III, p.925-926, grifo nosso).

\footnotetext{
${ }^{97}$ Ver Dicionário Luso-Brasileiro, 1974, p.195. Uma aventura infeliz, que lhe devia causar a morte, provocou a sua elevação. Pajém do rei da Polônia, João Casimiro V, teve uma vida dissoluta na corte. Surpreendido em flagrante delito de adultério por um nobre polaco, foi amarrado nu a um cavalo bravo, untado com alcatrão e abandonado à fúria do animal; este nascido nos desertos da Ucrânia levou para lá Mazeppa, que foi recolhido por alguns homens do campo. Lá ficou e viveu a vida inquieta e belicosa dos habitantes do lugar. Mais tarde, foi nomeado hétman, isto é, chefe dos cossacos da Ucrânia. Aliado de Carlos XII contra Pedro, o grande, envenenou-se depois da batalha de Poltava.
} 
Reparemos que neste fragmento, Eça se apropria dos processos de comparação e metonímicos para retratar o perfil literário de Chagas. Inicialmente, estende-lhe elogiosos adjetivos que excessivos pela ironia depreciam mais a figura do seu confrade. O jogo de comparações entre Chagas com as expressões "pena de pato" e "curta haste", leva o leitor a concretizar a idéia de mediocridade deste escritor. Sem falar da metonímia apresentada pela figuração da imaginação indomável que toma conta do escritor, ou seja, a parte (imaginação) que suprimiu o todo (Chagas).

Exposto isso, observemos o fragmento seguinte, onde podemos encontrar outra argumentação muito discutida na polêmica Brasil e Portugal e que aqui foi recuperada por Eça. Trata-se fundamentalmente, na concepção do autor de A relíquia, da permanente intenção que tinha Chagas em indispô-lo junto à nação. Talvez fundamentado nessa idéia, Eça tenha revidado à altura por meio de sua tentativa de imortalizar para sempre uma figura caricata de Pinheiro Chagas.

Tudo isso, na verdade, constituiria uma abominação, se se tratasse dum escritor que, nos seus escritos, pusesse ao mesmo tempo - mais severidade e mais perversidade. Teríamos então aqui uma dessas repulsivas tricas de polemistas rábula, que, retrucando a um artigo publicado há longas semanas, e de que ele supõe que o público já se não recorda, lhe atribui perfidamente toda a sorte de feias proposições, que o pobre artigo não encerra, com o fim de tornar o autor desagradável e antipático aos olhos dos simples e aos olhos dos esquecidos.(QUEIRÓS, CIFM, s.d, v.III, p.925, grifo nosso)

Recapitulando, talvez não se possa excluir o apadrinhamento ocorrido no concurso literário realizado pela Academia, se levarmos em conta as cotéries que existiam naquela época. No entanto, seria negligente de nossa parte não reconhecer diante do discutido que o aspecto que mais teria indignado Eça quanto ao Relatório de Chagas era o que menos tinha propriedade na sua argumentação, a exposição dos defeitos de A relíquia. Dessa maneira, 
não restaria a Eça a não ser dirigir habilmente a controvérsia com humorismo, levando o contendor e o leitor para o campo que lhe convinha. Finalmente, o autor de $O$ primo Basílio demonstrou, mais uma vez, a genialidade na construção irônica e sarcástica; por outro lado, Pinheiro Chagas estabeleceu uma crítica, em que as razões permanecem inteligentes e válidas até hoje. 
CAPITULO III

\section{Campanhas de um Dom Quixote literário}

"Julgava que essa advertência modesta, que eu me aventurava a fazer, lisonjearia os escritores, porque robustecia e confirmava a sinceridade do louvor. Enganava-me. As inteligências privilegiadas são tão acessíveis à ebriedade, produzida pelo incenso grosseiro, como os mais acanhados espíritos. Perante a vaidade todos somos iguais. Afinal caí em mim, e percebi o ridículo destas campanhas de D. Quixote”.

(Manuel Pinheiro Chagas, 1866)

O primeiro artigo de Pinheiro Chagas como crítico literário foi publicado na Política liberal sem a sua assinatura, intitulado Cenas da minha terra, dedicado a Júlio César Machado. Nesse texto, sua introdução destaca com breves palavras o jornalismo de Antonio Pedro Lopes de Mendonça, antecessor de Machado, que deixara o folhetim vítima da loucura $^{98}$. Contudo, será na revista da semana na Gazeta de Portugal a sua estréia oficial no jornalismo, sendo que este jornal e os folhetins no Jornal do comércio lançaram depois o seu nome para o plano de uma popularidade mais ampla. Quando intervém na Questão coimbrã já não é apenas o poeta que faz análises literárias cheias de lirismo e elegantes no estilo em auxílio do amigo Castilho, mas sim o crítico que polemiza com veemência ${ }^{99}$.

O seu espírito polêmico aliado a sua erudição e a uma poderosa memória ${ }^{100}$ percorreu todas as direções literárias criando uma vastíssima biblioteca. Contudo, é fato também, ou parcialmente o deve ser agora, que a atenção dispensada a Pinheiro Chagas nas histórias

\footnotetext{
${ }^{98}$ Esse artigo foi compilado, em 1866, no seu livro de crítica literária, Ensaios críticos.

${ }^{99}$ Ver Teixeira, 1949 , p. 183

${ }^{100}$ Uma das sátiras de Eça retrata e tenta reforçar a imagem de um Chagas desmemoriado, diferentemente daquilo que advoga Figueiredo (1881, p.78) ao expressar que "uma das coisas que mais espanta os que de perto o avaliam é a sua prodigiosíssima memória. [...] As datas precisas dos inumeráveis e mais secundários fatos da história nacional e estranha; as particularidades menos conhecidas das crônicas e das lendas; tudo sua memória reproduz com prontidão e exação admiráveis."
} 
literárias tem um caráter depreciativo que se estende ao seu espólio literário. E devido a isso, não se percebe por parte da crítica especializada, pelo menos na bibliografia que dispomos, uma preocupação em reorganizar e reavaliar o conjunto centenário da obra desse autor. Sempre as citações sobre Chagas com que nos deparamos giram em torno das seguintes situações, a de ter participado da Sociedade do elogio mútuo; de combater nas querelas Coimbrã e Faustina ao lado de Castilho; de ser o autor do célebre Poema da mocidade (1965) que desencadeou, graças ao prefácio de Castilho, a polêmica do Bom senso e do bom gosto $^{101}$; de manter sempre uma polêmica com seus oponentes políticos e literários; como estadista reacionário que defendeu a proibição das Conferências do Cassino e, por fim, como o último escritor que cultuou o Ultra-romantismo. E a associação de todos esses fatores tende a colocar em dúvida a qualidade do conjunto de sua obra, bem como a sua atuação como crítico.

E como era a crítica nesse tempo? Quem nos esclarece é Mendes (1997) em uma das abordagens que faz em seu texto sobre a Questão coimbrã. Esta autora reserva um espaço para discutir sobre o desajuste das técnicas da crítica literária aos novos problemas portugueses por ambos os lados dos polemistas. Para Margarida Mendes, os conceitos usados ainda eram os da poética e retórica antigas, como "harmonia, decoro, bom gosto, ornato, sobrecarga, dureza do verso, o mover, deleitar, instruir, a clareza versus obscuridade, os erros prosódicos, a infração dos preceitos da elocução, os cultismos, o bem e o belo, a pureza e, sobretudo, o ‘gongorismo’ várias vezes evocado”. (MENDES, 1997, p.457). A falta de domínio de modelos críticos mais modernos faz com que a maioria das intervenções caminhe para o campo moral e político, um tanto quanto extremista e

${ }^{101}$ Cf. Reis, 1990, p.19 - A Questão coimbrã põe em destaque a nova concepção ética da literatura e da missão do escritor. Representa-se como oposição ao sentimentalismo e ao academismo dos ultra-românticos, mas também propõe um avanço nas mentalidades da época que, mais tarde, culminará em termos programáticos com As Conferências do Cassino. 
maniqueísta. Por outro lado, isso não impede que todos reconheçam as falhas artísticas das primeiras obras de Teófilo e de Antero, bem como a decadência da escola oficial.

Apesar dessa teoria de Mendes (1997), tentaremos neste espaço discutir e demonstrar que há críticas relevantes de Pinheiro Chagas que merecem das histórias literárias uma atenção desvencilhada da imagem negativa a que o seu nome está ligado desde 1865 . E como esta, tão denegrida após as polêmicas com Eça e os dissidentes de Coimbra, tem sido passivamente aceita por gerações sucessivas de críticos que, às vezes, até mesmo recuperam alcunhas e expressões satíricas direcionadas a Pinheiro Chagas nos textos de seus desafetos.

Inicialmente, vale esclarecer que quatro nomes destacavam-se na crítica literária por volta de 1865, Lopes de Mendonça, Antonio Feliciano de Castilho, Antero de Quental e Pinheiro Chagas, esses dois últimos com apenas vinte e três anos de idade. Apenas um desses quatro nomes não haveria de participar decisivamente da deflagração da Questão coimbrã, Lopes Mendonça que nessa época já havia morrido. Contudo, esse intervirá de forma indireta na disputa no sentido de que suas idéias seriam aproveitadas por Antero na contenda de 1865. Hess (1978) ressalta que para Lopes de Mendonça a tarefa da literatura era acompanhar e interpretar a evolução da sociedade e a crítica literária deveria julgar uma obra pela sua afinidade com a época a que pertence. Em contraponto à crítica de Lopes de Mendonça, Hess (1978, p.30) sempre coloca a de Pinheiro Chagas, sugerindo que as concepções literárias deste seriam reconstituídas a partir das suas simpatias e antipatias literárias. Se a obra de Hess (1978) privilegia os impulsos da Geração de 70 na renovação da lírica moderna em Portugal, mesmo às vezes mostrando-se imparcial quanto à obra de Pinheiro Chagas, era de se esperar que houvesse referências marginais à crítica deste, determinadas por um momento literário no seu biografismo. Assim, não é surpresa para 
nós, Pinheiro Chagas ser citado como um crítico ligado às convenções de uma crítica que presta favores, tudo aquilo que os coimbrões combatiam na tentativa de moralizar o cenário literário português.

Pinheiro Chagas repugná-lhe o romantismo como movimento social e humanitário tendente a dignificação do homem, como Hugo o entendia na Contemplations. Quando a idéia de progresso permanece vaga e sem força vinculativa, Pinheiro Chagas manifesta o seu apreço por essa lírica. Assim, para ele, a verdadeira poesia do progresso é representada por Antonio Augusto Soares de Passos. [...] vendo Pinheiro Chagas na literatura um aprazível bem de consumo, o seu princípio de Crítica literária é o de não ferir a susceptibilidade de nenhum autor influente. Desde o início da sua carreira de crítico literário e de poeta, Pinheiro Chagas pertenceu ao número dos mais fervorosos adeptos de Castilho. [...] Que escrevendo à maneira neoclássica, ou à maneira romântica, Castilho demonstrava sempre, a seu ver, uma maestria inigualável.(HESS, 1978, p.33-4)

A partir deste fragmento, em que Hess descreve a crítica de Chagas, é quase impossível não pensarmos na parcialidade dos princípios críticos do autor d' A morgadinha Val Flor. Outro ponto destacado aqui se refere às concepções literárias de Pinheiro Chagas, que vê como méritos de Castilho a sua capacidade de adaptação às flutuações da moda literária. Contudo, Antero irá condenar essa particularidade literária de Castilho. Temos, portanto, o confronto de dois pontos de vistas, Antero que vê um oportunismo literário em Castilho e Pinheiro Chagas que exalta as aptidões deste, que escrevia de forma inigualável quer à maneira neoclássica ou à maneira romântica. 


\section{1.}

\section{A crítica de Pinheiro Chagas sob nova perspectiva}

Como vimos, apesar de Chagas e Antero divergirem quanto à postura literária de Castilho, existem entre eles, por incrível que pareça, aproximações que foram reconsideradas pelo autor de Odes modernas, já no ano de $1872 .^{102} \mathrm{O}$ texto ao qual nos referimos é a tese apresentada por Pinheiro Chagas à cadeira de Literatura do Curso Superior de Letras, Desenvolvimento da literatura portuguesa (1872), uma refutação da História da literatura portuguesa de Teófilo Braga. Nessa tese, Braga discorre sobre a inexistência de uma literatura genuinamente nacional e a teoria do moçarabismo.

Segundo Ventura (1991), esse princípio foi formulado na História de Alexandre Herculano e recuperado por Teófilo Braga em seus estudos. Ambos acreditavam que uma raça mestiça, os moçárabes, teria se formado na Península Ibérica, com a fusão entre árabes e romano-godos. Os moçárabes foram os causadores da extinção da escravidão, implantação de municípios, comunas, conselhos e criação da administração pública. Braga fundamentou suas idéias na tríade de Max Müller, com a divisão dos povos em três ramos: arianos, semitas e turanianos. Os turanianos, oriundos da Ásia, teriam prevalecido na Europa antes da invasão ariana, criando o lirismo da poesia popular européia mediterrânea e da península Ibérica. Transplantado para o Brasil com a colonização portuguesa, o lirismo ibérico sofreu modificações devido ao contato com as manifestações poéticas dos índios tupis de origem asiática.

\footnotetext{
${ }^{102}$ Ver Carreiro, I, 1948, p.411-440. A apreciação literária feita por Antero sobre o texto de Teófilo Braga gerou uma polêmica que levou ao corte de relações entre os dois.
} 
Antero, que também havia feito um artigo opondo-se às opiniões de Braga, abre o seu estudo sobre o texto de Chagas com a seguinte referência: “[...] Nesta resenha das opiniões, emitidas pelos escritores da nova geração, sobre o sistema geral da nossa literatura, fora injustiça não consagrar algumas linhas ao trabalho do Sr. Pinheiro Chagas, já pelo valor do trabalho em si, já pela posição que seu autor ocupa entre os escritores moços." (QUENTAL, s.d [1872],vol.II,p.235). E o autor das Odes modernas prossegue em sua exposição recuperando as conclusões da tese de Chagas, que lhe parecem lúcidas e sensíveis, salvo leves diferenças, que não desmerecem o estudo. Antero, em seguida, faz uma breve alusão às épocas dos intensos embates em que os dois participaram em lados opostos: “[...] pelo menos neste sereno campo da história literária, onde se descansa, entre flores ideais, de tantas lutas que separam os homens de hoje - em comunhão de vistas com um espírito tão gentil e cultivador”.(QUENTAL, s.d [1872],v.II,p.236). Para nossa surpresa, um dos pontos que mais teria impressionado Antero no texto de Chagas fora o caráter eminentemente nacional de sua crítica. Partindo dessa perspectiva, acreditamos que exista um desacordo entre o pensamento anteriano de agora e aquele do projeto Ibérico ${ }^{103}$, já que no texto de 1868 explicitava veementemente o seu antipatriotismo ${ }^{104}$. Além disso, não podemos nos esquecer que, por inúmeras vezes, Chagas será condenado pelos seus adversários literários por seus ideais patrióticos, considerados como conservadores e chauvinistas.

\footnotetext{
103 Ver Quental, s.d [1868], II, p.82. Antero considera: “[...] Eu, por mim, pondo de parte toda a poesia e toda a sentimentalidade, contentar-me-ei de afirmar aos patriotas portugueses esta verdade de simples bom senso: que, nas nossas atuais circunstâncias, o único ato possível e lógico de verdadeiro patriotismo consiste em renegar a nacionalidade."

${ }^{104}$ Caracteriza-se nessa passagem do nosso texto uma das contradições reconhecidas por Antero, aqui especificamente das fases pelas quais passaram os seus sentimentos patrióticos: "Ria-se das minhas contradições, mas confesso-lhe [ a Oliveira Martins pouco antes de morrer] que me causa isto má impressão e quase me esgota. Não me sinto português, mas tenho o sentimento da solidariedade com o grupo social orgânico e histórico a que pertenço". (Antero, 1891, In: Carreiro, 1948, p.291)
} 
O passo seguinte da análise de Antero é expor uma síntese das conclusões de Chagas,

identificando as aproximações entre ambos.

$1^{\circ}$. Que o povo português não é constituído por uma raça especial, a que se dê o nome de moçárabe, comprimida sempre e atrofiada nas suas criações pela nobreza, constituída por outra raça, a que se dê o nome de asturiana.

$2^{\circ}$. Que nem as induções filológicas, nem os fatos históricos permitem que se dê ao povo português uma origem germânica, e a aristocracia uma origem latina; que, pelo contrário, se algum dos elementos constitutivos da raça peninsular predomina no povo, deve ser o elemento hispanoromano, e na aristocracia o elemento gótico.

$3^{\circ}$. Que teve o povo português, durante a idade Média, uma vigorosa existência, manifestada politicamente pela robusta vida municipal, literariamente pela sua colaboração nos vastos romanceiros peninsulares, e pelas crônicas de Fernão Lopes.

$4^{\circ}$. Que a literatura aristocrática aceitou a influência provençal, a influência da França do Norte, e influência italiana, como sucedeu nos outros reinos da Península.

$5^{\circ}$. Que no século XVI a reação latinista imperou aqui, da mesma forma que em toda a Europa, mas que a originalidade do nosso povo se manifestou com um vigor admirável na epopéia de Camões no Teatro de Gil Vicente e nas crônicas dos descobrimentos.

$6^{\circ}$. Que a decadência da nossa literatura foi devida a três deprimentes: o despotismo monárquico e centralizador, que imperou em todas as raças neolatinas, o despotismo religioso que atuou com a mesma energia na Itália e principalmente na Espanha e a perda da nossa nacionalidade, que foi uma causa especial, devida a fatais circunstâncias históricas.

(QUENTAL, s.d [1872], vol.II, p.235-36)

No mesmo texto que vimos comentando, Antero concorda com Pinheiro Chagas que

para se entender a história da literatura portuguesa não se pode opor ciência e patriotismo, e

ratifica com veemência que somente por meio desse último se pode desvendar a essência do

povo português.

[...] Mas não é isso o que se dá com a história literária portuguesa. Cá não existe essencialmente tal oposição. Um largo patriotismo é perfeitamente compatível com a imparcialidade da crítica, no estudo dos nossos poetas, dos nossos escritores, durante 600 anos, que não foram sem glória nem originalidade. Vou mais longe. Direi que esse largo e justo sentimento patriótico é até indispensável para bem compreender o que houve neste povo, na sua vida agitada, dramática, heróica, a sua alma, a sua realidade moral. (IBIDEM, p.237) 
Em seguida, Antero estende-se numa linha filosófica sobre o pensamento do "ser português" diante do passado histórico de Portugal. Elogia as idéias tão bem discutidas de Chagas em estabelecer que a ciência seria o suporte imprescindível para reafirmar que a história literária dos portugueses teve sim uma importância fundamental no universo europeu.

Sim existimos! E existimos como homens, pensando, sentindo, querendo, obrando. Criamos, descobrimos, combatemos; e podemos dizer ao mundo: 'Aqui está o que nós amamos! Aqui está o que nós odiamos!' E o que é isto senão sentir-se português e ser patriota? E como, sem isto, se poderá compreender o que pensaram e escreveram portugueses, e pensaram e escreveram como portugueses?

A ciência não contradiz isto. Parte, pelo contrário, deste ponto de partida. E é em nome dela que o Sr. Pinheiro Chagas diz com tanta verdade como energia: 'os portugueses não são os párias literários da Europa. (IBIDEM, p.237).

Para Antero (s.d [1872], p.238), essa premissa de Chagas sobre a afirmação do passado seria necessária para poder incentivar o povo português - que vivia num "presente tão cheio de melancolia - a crer e confiar num futuro melhor", preparando-o corajosamente para esse. Logo em seguida, o autor de Odes modernas faz críticas ácidas às teorias de Braga que:

em nome de não sei que sonhada decadência das raças latinas, deprime sistematicamente quanto teve ou tem o nome de português, e nos aponta o ideal de um messiânico germanismo ( que nem talvez saiba definir), de uma absurda supremacia das raças germânicas, como a única salvação possível? (IBIDEM, p.238)

Registremos que o texto de Antero pressupõe que a saída não estava nessa estranha "salvação", para a qual seria necessário deixar de serem portugueses. E contra-ataca a mais tirânica das propostas, a abdicação do pensamento lusitano por meio da imitação da cultura germânica, e conseqüente descrença da própria capacidade e da vida moral. 
Aconselham-nos que imitemos pacientemente, sem crítica e sem protesto, os exemplos dos nossos mestres e senhores, os alemães, únicos pensadores e sábios, ao que parece, sem verem que imitação importa abdicação, e que um povo que abdica do seu pensamento é um povo que se suicida! (IBIDEM, p.238, grifo do autor)

Dessa maneira, Antero conclui seu pensamento sobre essa terrível proposição.

Sejamos nós mesmos. Tenhamos esse valor, e tudo se tornará possível. Antes de tudo, convém crermos em nós mesmos, no passado como no presente. Crer em si não é adorar-se. Podemos ter essa crença, sem santificarmos por isso os nossos vícios, sem nos iludirmos sobre as nossas misérias antigas e modernas, sem nos endurecermos na nossa ignorância e confusão. Podemos crer em nós, e confessarmos os nossos erros: quem se suicidou só por que uma vez se reconheceu pecador? Se erramos e pecamos (e pecamos e erramos bastante), reformemo-nos corajosamente, mas seguindo sempre uma inspiração própria, consultando a nossa alma, não a dos outros, a voz da nossa consciência, não a da consciência alheia. [...]. (QUENTAL, s.d, v.II, p.239).

Passemos, agora, à explicação daquilo que seria a leve discordância entre os pareceres de ambos. Estamos aqui nos referindo ao espírito revolucionário, muito presente no projeto defendido por Antero sobre a União Ibérica por meio da República Federalista, então representada em Espanha ${ }^{105}$. No entanto, tempos depois, Antero irá escrever em sua carta autobiográfica que esse projeto não passava de "uma grande ilusão", do qual ele só desistiu, como de muitas outras desse tempo, depois de experiências frustradas ${ }^{106}$.

Para toda a Península não há hoje senão uma única política possível e da federação republicano-democrática. E, em face desta formidável unidade de interesses, de idéias, de vontades e de aspirações, que podem as barreiras da nacionalidade significar mais do que uma tradição, um símbolo poético, cujo sentido se perde de dia para dia, até se tornar de todo incompreensível, até desaparecer? Moralmente essas barreiras caíram já. Para as consciências mais retas, para as inteligências mais seguras dos dois povos, unidas nos mesmos desejos e num pensamento comum, a nacionalidade não passa de um obstáculo desgraçado, resto das

\footnotetext{
${ }^{105}$ Essas idéias de Antero de Quental estão presentes no folheto Portugal perante a Revolução de Espanha (1868).

${ }^{106}$ Ver Carreiro, 1948, p.289-295
} 
hostilidades fatais de séculos bárbaros, e que só por um lamentável acordo dos interesses da minoria dominante e dos prejuízos da multidão ininteligente se tem podido sustentar. Mas esse acordo desfez-se. O irresistível movimento democrático da nossa sociedade vai tornar inevitável a queda da nacionalidade, nas opiniões, a princípio, e mais tarde nos fatos, no grande dia do abraço fraternal das populações da Península Ibérica. Organizado o federalismo democrático em Espanha, é um fato, um fato visível e soberano, que se torna o alvo das nossas aspirações, o nosso exemplo, o programa do único partido com vida e significação em Portugal. [...] Em qualquer dos dois casos, a política, para nós portugueses, é sempre a mesma: o nosso caminho está traçado, invariável e superior ainda às oscilações e tremores do terreno por onde a força inexorável das coisas o obriga a passar. Em qualquer dos dois casos, a nacionalidade, esta estreita nacionalidade dentro da qual nos está comprimido a monarquia burguesa, tem de ser sacrificada, quer no fato de uma revolução, quer no programa de um partido revolucionário, a uma forma mais larga, mais livre, e mais fraternal. Em qualquer dos dois casos, para todos os elementos moços, inteligentes, ativos da sociedade portuguesa, não há outra saída aberta senão esta: a democracia ibérica; nem outra política, política capaz de idéias, de futuro e de grandeza, possível em Portugal, senão esta: a política do Iberismo [...]. O patriotismo pode simbolizar-se hoje numa idéia falsa e estreitíssima: mas nem por isso deixa de ser um sentimento respeitável. [...] Concebe-se facilmente que esses interesses deixem de ser homogêneos, que essas idéias se possam contradizer: concebe-se que a forma nacional, em vez de realizar o ideal de pleno desenvolvimento material e moral simbolizado no amor pátrio, lhe sufoque os impulsos mais generosos, e atraiçoem as suas mais legítimas aspirações. [...] Se não é possível sermos justos, fortes, nobres, inteligentes, senão deixando cair nos abismos da história essa coisa a que já se chamou nação portuguesa, caia a nação, mas sejamos aquilo para que nos criou a natureza, sejamos inteligentes, nobres, fortes, justos, sejamos homens, muito embora deixemos de ser portugueses. Uma nação moribunda é uma coisa poética: infelizmente a melhor poesia, em política, não passa de uma política medíocre. Chorar, recordar-se, ou ameaçar em sonoros versos, pode ser extremamente sentimental: mas não adianta uma polegada os nossos negócios .... Eu, por mim, pondo de parte toda a poesia e toda a sentimentalidade, contentar-me-ei de afirmar aos patriotas portugueses esta verdade de simples bom-senso: que, nas nossas atuais circunstâncias, o único ato possível e lógico de verdadeiro patriotismo consiste em renegar a nacionalidade. (QUENTAL, s.d [1872],vol.II, p.77-82)

Até onde sabemos, Pinheiro Chagas era contrário ao projeto federalista de integração de Espanha e Portugal por acreditar que seria um retrocesso histórico para Portugal. Vejamos a sua defesa: 
Já se vê, portanto, que nós não temos o fetichismo monárquico, e que, apesar de entendermos sinceramente que as instituições atuais asseguram a Portugal a independência e a liberdade, e que devemos, portanto, defendê-las e sustentá-las com toda a energia, não nos persigamos horrorizados quando ouvimos falar em república. Rimo-nos, porém francamente ao vermos a Espanha fazer propaganda republicana. Faz-nos lembrar um desastrado a quem rebentam na mão todas as espingardas, e que aconselha com toda a seriedade aos vizinhos o uso das armas de fogo, e se presta a ensinar-lhes o modo de se servirem delas.

Ao lado, porém da propaganda republicana há outra que devemos repelir ainda com mais energia, é a propaganda ibérica. Essa revela apenas uma ignorância absoluta da história, uma ignorância completa dos sentimentos portugueses, e uma obstinação ridícula. Não há efetivamente um só espanhol, que, ainda que se queira mostrar respeitador da vontade nacional, ainda que declare com a maior efusão, e com a maior sinceridade, que julga atualmente inexeqüível a união ibérica, não acaricie contudo a idéia de que é esse um fato que se há realizar pacificamente no futuro, com alegre assentimento de ambos os povos. [...]Desgraçado do estrangeiro que ousa violar uma nacionalidade quando a encontra abatida; é na escravidão que se retempera o heroísmo! É nas humilhações dos sessenta anos, que a aristocracia venal, que o povo fraco e tímido de 1580 se vão transformando na heróica fidalguia e no intéprido povo, que no dia $1^{\circ}$. de dezembro fizeram tremular de novo, solta às auras da liberdade, a bandeira de Aljubarrota e de Ormuz, a gloriosa signa de Vasco da Gama, que foi a estrela dos aventurosos navegantes, e a esplêndida musa de Camões!(CHAGAS, Pensamentos Ibéricos,1873, p. 184-90)

Pinheiro Chagas ${ }^{107}$ considera um suicídio da nação portuguesa o seu retorno à União

Ibérica, como foi à época do século XVII, depois que Portugal a duras penas reconquistou a sua independência em 01 de dezembro de $1640^{108}$. Para Chagas, esse tema está intimamente

\footnotetext{
${ }^{107}$ Merece uma nota o fato de que esse período de turbulências de idéias em relação à união ibérica republicana foi crucial para que nosso autor escrevesse os dois romances históricos A Máscara Vermelha (1873), a sua continuação O Juramento da Duquesa (1873) - que atingem o período de reconquista da independência nacional - e A Mantilha de Beatriz ${ }^{107}$ (1878). Apesar de serem tipos distintos de ficção, podemos encontrar nessas três obras além das digressões do narrador com suas importantes implicações ideológicas - passagens históricas ou temas ligados à questão ibérica, nacionalidade portuguesa e literatura nacional. Dessa maneira, a proposição da questão identitária portuguesa, tanto literária quanto histórica, permeará todas as três narrativas.

${ }^{108}$ Ver Serrão, 1992, pp.508-19. O desastre militar de D. Sebastião, a batalha de Alcácer-quibir travada em 4 de agosto de 1578, culminou na morte do rei e na perda da independência de Portugal. Sem deixar herdeiros, D. Sebastião legou a seu país um caos dinástico, assumindo o trono luso, provisoriamente, o cardeal Henrique que faleceu tempos mais tarde. Sem um sucessor imediato ao trono português, surgia agora uma oportunidade aos reis espanhóis de obterem Portugal. Felipe II, com descendência portuguesa não deixou passar essa oportunidade. E ao assumir o trono da península Ibérica, jurou manter a autonomia administrativa e jurídica dos portugueses. O interesse maior do monarca não eram as rendas de Portugal ou do seu império colonial, mas manter a tão querida integridade política da Península Ibérica. Mesmo sendo um governo de conquistar a confiança do povo português, difundiu-se pelo país aquilo que Oliveira Martins chamou de "a doença do sebastianismo". Enquanto outros povos europeus se modernizavam, tentando expandir as coisas da Renascença, os portugueses alinhavam-se com um messianismo que se perdia nos tempos bíblicos, nas profecias de Isaías e de Davi. O sebastianismo virou uma fé nacional, servindo para a exploração da crendice popular. Quando se consagrou a União
} 
ligado à depreciação da ciência portuguesa desse período, tese que é recuperada na refutação que Chagas faz ao texto de Teófilo Braga sobre a literatura, em que aquele reafirma que: "Os portugueses não são os párias da Europa”. A sua intenção consistia em convencer o público:

[...]de que a história da literatura portuguesa, tão mal apreciada pelos próprios que a cultivam, não é menos gloriosa do que a nossa história política, e de que é o povo que abriu com as armas novos caminhos à civilização, também nas letras deu modelos, que as literaturas estrangeiras admiraram e imitaram.(CHAGAS, 1876, p.104)

Nessa passagem, Chagas cita um ponto importante de suas idéias no que diz respeito à matriz dramática ser Portugal e não Espanha quando do período da Península Ibérica. Conforme Chagas, Gil Vicente seria o iniciador da literatura dramática como espelho da sociedade, já no século XVI. Dessa forma, o teatro espanhol não só sofreu influências da dramaturgia vicentina como a teria como matriz nas comédias de observação. O autor de Ensaios Críticos ainda ressalta que na maioria dos gêneros literários das letras peninsulares tiveram os portugueses o mérito de serem os iniciadores ${ }^{109}$. Nosso autor sinaliza que o desprezo dado pela historiografia universal às iniciativas literárias de Portugal é muito mais um problema do próprio olhar português, que não reconhece a sua importância no desenvolvimento do espírito humano por meio da arte.

Ibérica, a Espanha vivia um momento único de esplendor em sua história. Era a sua idade do ouro, todos os gêneros literários vieram à luz: o épico, o lírico, o dramático e o cômico. No entanto, nessa mesma época houve uma conjugação de desastre que enfraqueceu politicamente e economicamente o reino espanhol. E em 1 de dezembro de 1640, deu-se a rebelião bem sucedida do Duque de Bragança em Portugal, apoiada de longe pelo Cardeal Richelieu da França. Proclamando-se Rei de Portugal como D. João IV, Portugal recuperara a autonomia pondo fim ao que os historiadores românticos, como Chagas (1873, p.185-189), chamaram de "cativeiro", período pelo qual as terras lusitanas viveram sob “a opressão de Filipe II". Durante 60 anos, de 1580 a 1640, Portugal estivera ligado à Espanha, e o Brasil colonial também.

${ }^{109}$ Ver Chagas (1867, p.68-104). Esse crítico considera que as obras de origem portuguesa em cada gênero foram: nas novelas de cavalaria o Amadis de Gaula, escrito por Vasco de Lobeira; na comédia Gil Vicente, com Inês Pereira; na tragédia clássica foi a obra Castro de Ferreira e no romance pastoril, Diana de Montemayor de Jorge de Montemor. 
Deixemos agora o século XIX e passemos ao seu sucessor. A próxima crítica em questão será a de Sayers (1983). Esses estudos nos esclarecem algumas informações importantes para compormos a nova imagem de nosso autor, principalmente em relação à literatura brasileira. O primeiro deles é que Pinheiro Chagas foi uma das autoridades no periodismo do século XIX, que ao longo de toda a sua atividade jornalística promoveu e apreciou a literatura brasileira. Para o crítico norte-americano (1983, p.194), o autor do Poema da mocidade se destacava em relação a outros críticos literários da época, como Ramalho Ortigão, Teófilo Braga e Sampaio Bruno, "no que se refere à influência jornalística e duradoura dedicação às letras brasileiras, ninguém se pode comparar a Manuel Pinheiro Chagas ${ }^{110 "}$. Sayers em seu artigo, Machado de Assis no Portugal do século XIX, ${ }^{111}$ faz uma referência específica à crítica de Pinheiro Chagas.

Um dos primeiros bons estudos sobre Machado foi publicado por Manuel Pinheiro Chagas em 1866, no Anuário do Arquivo Pitoresco. Nele, Pinheiro Chagas discute as obras de Machado que havia lido - A Corina, Os Deuses de Casaca e a crítica à peça de Mendes Leal, Os Primeiros Amores de Bocage, publicada em 1865 no Diário do Rio de Janeiro. O autor do estudo revela grande discernimento para um crítico de vinte e quatro anos de idade, quando diz do brasileiro. 'simpatizei vivamente com o escritor, que nesses fragmentos do seu lavor literário revelava o que mais valia tem neste confuso exame da literatura, uma individualidade pronunciada e característica, [...]' e, depois de afirmar que a literatura brasileira tende a ser retórica e declamatória, prossegue: ‘ Machado de Assis (sic) não possui nem a mais leve sombra desse defeito; a sua índole é até de todo avessa a esses recamos despropositados, e não sei mesmo se diga que é muito possível que a eloqüência empolada de algum Marini brasileiro desinche de súbito ao divisar nos lábios de Machado de Assis o sorriso malicioso, que diz tão bem com a sua fisionomia literária. Não nos esqueçamos que este escritor é um dos mais distintos, se não o mais distinto, dos folhetinistas do império. (SAYERS, 1983, p.128-129)

\footnotetext{
${ }^{110}$ Ver Sayers, 1983, p.194 - Os estudos literários de Pinheiro Chagas abrangem as obras de Machado de Assis, Alencar, Cassimiro de Abreu etc. Sem contar que promovia publicações de escritores brasileiros no seu jornal Diário da manhã, tempos depois chamado de Correio da manhã.

${ }^{111}$ Ibidem, p.126 - Machado jamais recebera em Portugal a devida fama de romancista que lhe convinha. Os lados de crítico e poeta, mais presentes no início de sua carreira, foram os de maior destaque em Portugal.
} 
Sayers (1983) prossegue que a primeira crítica mais extensa de Pinheiro Chagas sobre o autor de Dom Casmurro foi em 1873, em Brasil $^{112}$. O seu objetivo era tratar a literatura brasileira de modo geral, mas acaba por focalizar num maior espaço, a Ressurreição de Machado. As impressões de Sayers foram de que Pinheiro Chagas gostara do livro, mas que este preferia o Machado poeta ao ficcionista, uma vez que Falenas era uma obra impecável. Já Ressurreição, para Chagas, era um "esboço” e não uma obra acabada. Embora isso, Chagas conclui:

\begin{abstract}
Mas o que não se pode deixar de admirar-se neste belo livro é a encantadora sobriedade do estilo, o fino toque de um lápis prestigioso, e o delicado estudo de uns certos cambiantes de paixão, que revelam em Machado de Assis um escritor fadado para os estudos psicológicos, que são a base principal do romance na sua acepção mais elevada. (CHAGAS, 1873 apud SAYERS, 1983, p.135)
\end{abstract}

Infelizmente, não tivemos acesso a nenhum dos artigos críticos de Chagas sobre Machado de Assis, o que nos impossibilita apresentar as concepções do crítico português sobre o escritor brasileiro. Por outro lado, só de colocarmos em evidência o período do primeiro artigo crítico sobre o autor de Memórias póstumas de Brás Cubas que é o mesmo da tumultuada Questão coimbrã, ajuda-nos a desmistificar a idéia de mediocridade dos estudos críticos de Chagas tão destacada pelas histórias literárias, a partir da controvérsia de 1865-66.

No seu outro artigo, A literatura brasileira no Portugal oitocentista: Os críticos, Os jornais, as revistas, Sayers (1983) reforça que mesmo não sendo Pinheiro Chagas o primeiro crítico português a escrever um artigo pormenorizado sobre um escritor brasileiro, as suas contribuições foram valorosas para a divulgação da literatura brasileira em

\footnotetext{
${ }^{112}$ Cf. Sayers, 1983, p.135. Importante revista editada por Antonio Feliciano de Castilho entre 1871 e 1874, e não a outra de mesmo nome, O Brasil, edição para a América do Sul, da qual Castilho também foi diretor, com edições contemplando o período de 1873 a 1877.
} 
Portugal. Pois, como bem diz uma escritora e crítica contemporânea de Chagas, Maria Vaz de Carvalho ${ }^{113}$ (1890, p.305), “os leitores [...], leram por certo, porque ninguém deixa de ler o que Pinheiro Chagas, escreve e pensa".

A Pinheiro Chagas, porém, mais do que a qualquer outro crítico, a literatura brasileira deve a sua aceitação em Portugal, porque durante a sua carreira de jornalista e crítico, que durou quase trinta anos ele escreveu incansavelmente sobre o Brasil e sua literatura. Os seus escritos encontram-se em livros, revistas e jornais e também em prefácios a edições portuguesas de livros brasileiros. (SAYERS, 1983, p.210)

Nosso trabalho visa mostrar como a crítica de Pinheiro Chagas, tão negligenciada pelas histórias literárias, vai sendo timidamente descortinada por alguns trabalhos que abandonam um pouco o biografismo para se dedicarem com eqüidade às considerações do crítico.

Agora, trataremos do estudo de Fernanda Maria Abreu (1994), que se dedica ao estudo da obra de Cervantes no Romantismo português. O primeiro destaque que Abreu (1994, p.83) faz em relação ao prefácio de Chagas está na referência de ser "[...] o mais importante texto crítico que acerca de Cervantes e do Dom Quixote se produziu em Portugal durante o século XIX”. Essa introdução é parte integrante de uma tradução que constitui um dos marcos mais notáveis da história da recepção do Dom Quixote em Portugal, a dos Viscondes de Castilho e de Azevedo ${ }^{114}$. Abreu destaca o valor do texto crítico de Pinheiro Chagas e denuncia o silenciamento desse estudo em relação a outros de igual importância junto às bibliotecas cervantistas. Como citamos a seguir:

\footnotetext{
113 Trecho extraído de uma análise que essa autora faz do relatório de Pinheiro Chagas sobre A relíquia. Em outro momento, Carvalho (1906, pp.119-32) faz uma crítica sobre a vida literária de Chagas e ressalta, dentre a vasta produção literária desse autor, os artigos políticos, como $O$ joelho, que provocou muitos risos nos leitores da época.

${ }^{114}$ Ver Abreu, 1994, p.82. Esta tradução começou a ser realizada pelo $2^{\circ}$ Visconde Júlio de Castilho, sendo interrompida por morte deste; foi continuada pelo Visconde de Azevedo e, de novo interrompida pelo falecimento do tradutor, finalmente a tradução foi concluída por Manuel Pinheiro Chagas que fora, antes, o autor do prefácio. Para Abreu, essa tradução será uma influência a outras que a sucederão devido ao trato cuidadoso e apurado com que foi feita.
} 
Pinheiro Chagas fez, na verdade, um Prefácio 'erudito e substancioso'. Ainda que, injustamente, na nossa opinião, não tenha logrado ocupar esse desejado lugar nas bibliotecas dos cervantistas, não figurando, por exemplo, na já aqui referida Guia de Drake/Finello (1987). Trata-se de um longo texto (págs. V-XXXIV), dividido em oito partes. Curiosamente, tal como Latino Coelho o tinha feito, também Pinheiro Chagas critica os "cervantistas" sobretudo os espanhóis: 'o cervantismo está sendo em Espanha uma monomania tão pouco razoável como o próprio dom-quichotismo'. E mostrando ter recorrido à mais recente bibliografia espanhola sobre Cervantes e o Dom Quixote, a crítica romântica (Diaz Benjumea, Mainez, Pellicer, Vicente de los Rios, Francisco María Tubino), dando contas das suas opiniões, rebate-as, nuns casos, partilha-as, noutros." (ABREU, 1994, p.83-4)

Abreu (1994), num dos pontos mais interessante do seu texto, aponta-nos a forte impressão que lhe deixou o estudo de Pinheiro Chagas sobre Cervantes e Dom Quixote. Para essa autora, de acordo com a análise que esse fez sobre Dom Quixote, em específico, o retrato de Dulcinéia - em que a crítica do século XIX dispensava-lhe somente uma visão romântica dessa personagem - Chagas estava à frente da crítica de seu tempo.

Numa crítica à interpretação que Mainez faz do retrato de Dulcinéia, mostra já Pinheiro Chagas uma nova sensibilidade - que talvez Jorge de Sena (1974, p.74) chamasse 'contra-romântica' - ao caráter paródico que Mainez não viu e que, sem dúvida, o dito retrato tem no texto de Cervantes. Recorrendo a outras obras de Cervantes, neste caso, uma das 'Novelas Ejemplares' - num interessante exercício crítico intratextual mostra ainda o que julgamos como uma marca de uma recepção que alguma crítica romântica nem sempre fez, isto é, a de separar Cervantes de Dom Quixote: 'Veja o Sr. Mainez! No entender de Cervantes, os maus poetas é que descreviam as suas amadas, como D. Quixote descreveu Dulcinéia, e contudo, o Sr. Mainez vai buscar exatamente esse retrato para o apresentar como um excerto do primoroso estilo de Cervantes!' (ibid.:VIII, nota 1). E para serenar a 'monomania quixotesca' e a 'monomania cervantesca' da crítica espanhola, recorre também Pinheiro Chagas aos grandes, e não espanhóis, historiadores da literatura espanhola: o suíço Sismondi e o norte-americano Ticknor, invocando ainda opiniões de Daniel de Foe e de Mr. Rawdon Brown, a propósito da versão ' dos que quiseram ver no $D$. Quixote uma sátira do imperador Carlos V'. (ABREU, 1994, p.84, grifo nosso) 
Certamente, ao expor a erudição de Chagas, Abreu (1994) demonstra que esse estudo além de apresentar firmes, claras e acertadas convicções literárias, ainda tenta dialogar com a crítica de maior renome na atualidade em matéria de Cervantes. E a primeira proposição simplista que tenta desmistificar é não ser Dom Quixote somente uma sátira da literatura cavaleiresca, quando não uma sátira particular feita a certas individualidades do tempo de Cervantes, como muitos cervantistas proclamavam. Ainda no trecho que evidenciaremos, Abreu (1994) elogia outra particularidade do estudo de Chagas, o caráter didático com que seu autor trabalha os aspectos histórico-literários da criação de Dom Quixote.

[...] desenvolve uma argumentação que nos interessa seguir pelo que nos ensina acerca de Dom Quixote e de algumas das circunstâncias históricoliterária da sua feitura. Em primeiro lugar, chama Pinheiro Chagas a atenção para o fato de a paródia - que ele considera, em nossa opinião com grande justeza, o 'processo quixotesco' - se poder aplicar igualmente ao gênero pastoril, e neste sentido, Cervantes ter feito paródia do pastoril na Galatea e no episódio de 'Marcela e Crisóstomo', inserto no Dom Quixote, sem que isso implique que o tivesse querido 'desacreditar'. Depois, admitindo-se 'a teoria de que se pode desacreditar com a paródia um gênero literário, a própria história não fica ao abrigo desse sistema'. (ABREU, 1994,p.85, grifo nosso)

Abreu salienta nesse trecho do texto de Pinheiro Chagas aquilo que a crítica cervantista menos simplista tem asseverado, que a literatura cavaleiresca extinguiu-se devido à evolução do gosto do público e não pelo Dom Quixote de Cervantes ${ }^{115}$. Por outro lado, Abreu ressalta que este teorema ainda hoje não é unânime junto à crítica especializada.

Não foi o D. Quixote que os matou, matou-os a lenta evolução do gosto, que, por uma transição cujas peripécias facilmente se podem seguir na

\footnotetext{
${ }^{115}$ Cf. Chagas,1878, p.XVI. Muitos críticos baseavam-se na afirmação do prólogo de Cervantes, onde este sustentava que o seu objetivo era desacreditar os livros de Cavalaria e acabar com tão nociva leitura. Contudo, Chagas contra-ataca que seria uma análise ingênua acreditar que Cervantes ousaria no século XVII assumir que estaria escrevendo um romance pelo simples fato de dar gosto e vida a sua fantasia. Chagas reforça que para Cervantes qualquer gênero estava a serviço da língua castelhana. Chagas, por fim, dá o tiro de misericórdia em tais afirmativas, ao expressar que se Cervantes estivesse indignado com os livros de cavalarias nunca teria feito elogios tão pomposos do Amadis de Gaula e do Palmeirim de Inglaterra.
} 
história literária da península, foi transformando o romance de cavalaria no romance pastoril. Em Portugal, a transição é visível na célebre Menina e Moça de Bernadim Ribeiro, romance de cavalaria que declina visivelmente para gênero bucólico. O que matou o romance de cavalaria não foi o D. Quixote, foi a Galatea, foi a Diana, foi a Astrea, foi a nova forma literária que vinha suceder à outra forma decrépita; matou-os o não corresponderem já ao ideal das novas gerações. (CHAGAS, 1876, p.XI)

Em seguida nos estudos de Abreu (1994), ela destaca, algo que já notamos em outros estudos críticos de Chagas, a maneira como este tenta unir os quadros históricos aos literários da época de produção da obra. Sempre dialogando com os grandes escritores e obras do tempo daquele que é o objeto de seu estudo. Especialmente aqui, num primeiro momento, ele discute o teatro no tempo de Cervantes, os principais escritores deste período, na dramaturgia espanhola como Lope de Vega e Calderón de La Barca; na inglesa Shakespeare. Chegando mesmo, numa extensa nota de mais de uma página, a fazer uma análise comparativa entre os teatros de Calderón e Shakespeare, ambos tematizando sobre um mesmo personagem histórico, Coriolano, concluindo, por fim, a superioridade do dramaturgo inglês ${ }^{116}$.

Ainda nessa passagem do texto, Abreu (1994) esclarece que Chagas, ao relacionar a história política com a literária, expõe uma interessante afirmativa ao generalizar uma relação intrínseca entre ausência de liberdade com a paródia e o burlesco: "Nas épocas em que a ausência de liberdade faz com que predomine na literatura o elemento frívolo, a paródia é um dos gêneros mais cultivados, o burlesco é uma das formas prediletas da arte".(CHAGAS, 1876, p. XIV).

Baseada nessa perspectiva, Abreu (1994) não se surpreende ao constatar que Chagas exibe, como em outros estudos e acontecimentos de sua vida, as qualidades de investigador

116 Cf. Chagas, 1878, p.XIII. "Shakespeare encontra-lhe com tal intuição as causas lógicas, que em circunstâncias idênticas o mesmo fato se reproduz; Calderón não vê no fato senão um pretexto para fazer umas variações dramáticas sobre o seu eterno tema de honra e do amor. Por isso, a linguagem de Shakespeare é rude às vezes, mas sempre verdadeira; a de Calderón é florida, mas declamatória." 
e polemista. Aqui, particularmente no seu prefácio, o crítico português aborda a questão da autoria da continuação do Dom Quixote, publicada sob o pseudônimo de Alonso Fernandez de Avellaneda ${ }^{117}$, mas que em sua opinião era Lope de Vega. Chagas, surpreendentemente, assume uma postura contrária em relação às considerações da crítica cervantista da época ao terminar sua argumentação sobre este fato, opinando que independentemente da identidade do autor, esse "imitando a letra do D. Quixote, não compreendeu o espírito". (CHAGAS, 1876, p.XXIX) Para chegar a esta conclusão, Chagas chegou mesmo a ler o livro de Avellaneda, só que na tradução francesa de Germond Delavigne, pois nas bibliotecas portuguesas não havia o original em espanhol ${ }^{118}$. Vale lembrar que o tradutor francês considerava o livro de Avellaneda superior ao de Cervantes. Abreu (1994) entende que talvez diante desta informação, Chagas tenha tido um interesse polêmico suplementar ao provar a superioridade de espírito do verdadeiro Dom Quixote.

Abreu (1994) compreende que as inteligentes considerações feitas por Chagas fazem que o seu texto supere teoricamente outros, produzidos no mesmo período, como o de Latino Coelho. Para ilustrar isso, essa autora comenta que Chagas (1876, p.XV) acrescentou, dentre outros, um dado novo sobre a perda do poderio cultural da França no século XVI em relação à influência que sofreu da literatura espanhola nos gêneros narrativos, em particular o pastoril e o picaresco. Para o autor do Poema da mocidade, a França que "perdendo nessa época o seu papel de nação - guia em literatura - tanto imita a

\footnotetext{
${ }^{117}$ Cf. Abreu, 1994, p.88. Pinheiro Chagas dedica todo o capítulo VII a esse fato. Contudo, ele retira toda a importância do ato vil da apropriação indevida da obra de Cervantes, que os mais fanáticos cervantistas abominavam. Chagas (1876,p.XXVIII) considera dentro do saber que lhe dá conhecimento da história literária, que " não seria de estranhar a publicação desta segunda parte, nessa época, sobretudo, em livros cuja sombra se acolhiam”. Chagas não só ameniza o acontecimento literário como dá outros exemplos de outras obras de sucesso com mesmo acontecimento.

${ }^{118}$ Ibidem, p.89. Segundo essa autora, não é de se surpreender a escassez de livros espanhóis em bibliotecas portuguesas e vice-versa. Reafirma suas idéias ao citar Rebelo da Silva: “ não se encontra um livro português em Madrid, nem um livro espanhol em Lisboa." Muitas das obras espanholas, Portugal só tinha acesso por meio de traduções francesas oitocentistas. Assim a França, em parte, era responsável pelo distanciamento cultural entre os povos peninsulares, pois os livros que circulavam em Portugal vinham precisamente de Paris.
} 
Espanha pastoril com D’Urfé, como a Espanha picaresca com Scarron"119. Para Abreu (1994), o objetivo maior dessa crítica de Chagas (1876, p.XVIII), aquilo que parece guiá-lo, é sua conclusão de que "a Espanha fez do romance herói-cômico do último cavaleiro a sua obra predileta e o seu grande livro nacional", pois o quixotismo, entendido como a adoração exclusiva dos grandes ideais é a essência do caráter espanhol.

Em seguida, Chagas, ao refletir sobre o processo de criação de Cervantes, evoca os princípios da crítica moderna de Taine, quando esse faz um juízo crítico sobre a obra inglesa de Ben Jonson. Contudo, Abreu (1994) se mostra surpresa, pois imaginava vê-lo adotar os mesmos fundamentos positivistas tainiano quanto a Cervantes, mas Chagas assume exaltadamente os pressupostos de uma crítica idealista, superestimando a inspiração e a genialidade. Lembramos que este tipo de defesa à escola idealista estará muito presente nos seus dois livros de crítica literária, Ensaios críticos (1866) e Novos ensaios críticos (1867) em contra-ponto à escola realista.

Longe, frios comentadores, as vossas estultas teorias e as vossas pedantes suposições! Pois imaginais, por acaso, que o poeta, o criador de almas, alegoriza quando escreve! Imaginais que Cervantes esteve pausadamente, no silêncio do seu gabinete ou do seu cárcere, fabricando duas figuras mecânicas que representassem esta a poesia, aquela a prosa, uma o espírito, outra a matéria, ou que esteve imaginando o símbolo da sabedoria, para o encarnar a figura de Dulcinéia! Supondes que esteve, no dizer de uns, tratando de apresentar a fórmula do verdadeiro cavaleiro andante, no dizer de outros, de lhe desenhar a caricatura, como o seu pífio contra-fator Avellaneda, ou como o seu chatíssimo imitador Inglês, Butler [...]! Não! O que o sublime escritor espanhol fez foi criar duas figuras profundamente humanas, não pelos processos mecânicos da alegoria ou da arte refletida, que nunca podem dar senão títeres, mas pela força irresistível e quase inexplicável da inspiração e do gênio. (CHAGAS, 1876, p.XV)

\footnotetext{
119 Ver Chagas, 1876, p.XV. O romance picaresco teve sua origem no Lazarillo de Tormes, de Diego Hurtado de Mendonza, agora era a vez dos poetas franceses receberem da Espanha, "o santo e a senha, imitam-no e ampliam-no, e Cirano de Bergerac, Dassoucy, Scarron e outros muitos dão a literatura burlesca da península Ibérica um largo apêndice francês. A par dos burlescos surgem os bucólicos, imitados também em França."
} 
Segundo Abreu (1994), Chagas a partir dessa sua máxima, viria a adotar a atitude e a linguagem do romantismo mais tópico, talvez como reação ao fantasma do naturalismo, contra cujas posições, na teoria como na prática literária, sempre se manifestou contrário em seus textos críticos. Superado isso, Abreu comenta que o ápice do texto de Chagas está na comparação que este faz entre a 'loucura sublime' de D. Quixote com a do El Rei D. Sebastião. Essa inusitada aproximação não será a única, haveria outras mais que provocariam em Abreu muita admiração. Ao término de seu prefácio, Chagas retoma novamente as comparações entre Camões e Cervantes, exaltando o espírito cavalheiresco que ambos representaram: "esse espírito cavalheiresco que foi, que há de ser sempre a glória e ao mesmo tempo a perdição dos dois povos peninsulares." (CHAGAS, 1876, p.XXXIII). Mais à frente, ainda na relação Cervantes-Camões, Chagas lança a proposição de que o Dom Quixote é uma epopéia impossível que o riso dissimula, numa atitude irônica. Abreu comenta que até então não tinha conhecimento de nenhuma outra crítica que abordasse tais idéias.

Mas Camões morreu com o espírito cavaleiresco, e Cervantes sobreviveu-lhe; por isso, aquele teve a epopéia, este o romance cômico; aquele pode exaltar a coragem, a valentia, abnegação, a glória de combater pelo seu rei, pelo seu Deus, e pela sua dama; Cervantes teve de rir dos que combatiam, pela sua dama, pelo seu deus, e pelo seu rei. Cervantes é Camões, depois da experiência de Alcácer-Kibir, é a cavalaria sobrevivendo a si própria, e rindo-se de se ver anacrônica. (IBIDEM, p.XXXIII)

E para confirmar a antecipação das idéias de Chagas em relação ao seu tempo, Abreu propõe:

Interessante ainda seria confrontar aquelas 'intuições' de Pinheiro Chagas com as afirmações que, a partir de pressupostos ideológicos e metodológicos aparentemente opostos, quase cem anos depois, faz Antonio José Saraiva (1961) num ensaio comparativo, sobre 'Os 
Lusíadas, o Quixote e o problema da ideologia oca'. Estamos já bem longe daquelas interpretações românticas que vimos ao longo do século XIX; por isso, as conclusões de Antonio José Saraiva nos permite admirar uma certa "modernidade", ainda que em conflito ou incompletamente delineada, naquelas observações de Pinheiro Chagas. Para o ensaísta de hoje, é com D. Quixote, não com Cervantes que se deve identificar Camões.(ABREU, 1994, p.91)

Dessa forma, Abreu (1994) entende que Chagas em seu texto percebeu nitidamente a diferença entre Cervantes e Camões através do riso, ou por causa dele. Esse riso cervantino que, para Abreu, irá ser encontrado em Garrett, Camilo e Eça, e que a crítica tem grande dificuldade em definir.

Chagas irá também trabalhar com o biografismo ${ }^{120}$ de Cervantes, baseado nos fundamentos românticos de que a vida e aventuras de Cervantes explicam, melhor do que todos os comentários, a idéia geradora de sua obra-prima. Dentre os elementos biográficos mais importante da vida de Cervantes, Pinheiro Chagas coloca em problemática a influência da literatura portuguesa na obra do autor do D. Quixote, já que este teria vivido em Portugal por um tempo.

[...] Em primeiro lugar, a literatura cavaleiresca, com $O$ Palmeirim de Inglaterra e o Amadis de Gaula - tido como português não só por Pinheiro Chagas, mas também pela maior parte do nosso século XIX, de Alexandre Herculano a Teófilo Braga - e ainda Gil Vicente. Quanto ao último, aponta Pinheiro Chagas relações de Sancho Pança com o Juiz da Beira, mas a crítica cervantina fala também, ainda hoje, de uma possível 'influência' de um episódio do Dom Duardos na gênese do Dom Quixote. (ABREU, 1994, p.88) ${ }^{121}$

\footnotetext{
${ }^{120}$ Cf. Abreu, 1994, p.87. "Uma parte importante desta biografia está constituída - como é habitual nas biografias portuguesas ou brasileiras de Cervantes - pela história das relações de Cervantes com Portugal, contemplando dois aspectos dessas relações: a presença de Cervantes em terras portuguesas, momento em que teria chegado mesmo a ter uma filha de uma portuguesa; e as referências a Portugal em sua obra."

${ }^{121}$ Ibidem, p.88. Segundo essa autora, Pinheiro Chagas ao defender as relações de Cervantes com Portugal manifesta a sua oposição às críticas mordazes que Camilo Castelo Branco faz a Cervantes em seu artigo, Manuel de Sousa Coutinho e Miguel de Cervantes.
} 
Outra passagem do estudo de Pinheiro Chagas que merece considerações de Abreu (1994) é sua análise sobre Sancho Pança. A autora portuguesa destaca que vale registrar a sensibilidade de Pinheiro Chagas num tempo em que a imagem de Sancho Pança não saía do clichê em que o tinham rotulado. Representação esta que ainda hoje é defendida por muitos no nosso meio literário. Chagas parece entender não somente a enorme dimensão humana de Sancho Pança como antecipa muitas considerações que só serão aprofundadas a partir do século XX.

É uma criação tão admirável como a de D. Quixote, esta de Sancho Pança, o homem chão e simples, todo prosa e todo bom senso, que se deixa conduzir por D. Quixote, porque o tem no mais alto apreço, e que mal pode compreender como toda a sua inteligência, toda a sua bravura, toda a sua erudição, o não preservam de confundir moinhos com gigantes [...]. Entregue a si mesmo no governo da Barataria, resolve todas as questões com acerto [...]. Este Sancho [...] é uma criação felicíssima que não saiu armado e completo como D. Quixote, da cabeça de Cervantes, mas que ele foi aperfeiçoando a pouco e pouco, à medida que lhe avultou na fantasia, e tomou as proporções de uma individualidade bem característica, em vez de ser, como ao princípio o concebera talvez, e como foi o de Avellaneda, simplesmente o gracioso da novela. (CHAGAS, 1876, p.XXXII, grifo do autor)

Para Abreu (1994), o estudo de Chagas tem uma modernidade no diálogo e na natureza de múltiplas interpretações do livro - que só será empreendida pela crítica do século posterior ao seu.

[...] não se tinha ainda estudado profundamente a raiz folclórica de Sancho Pança; não se tinha ainda falado, por exemplo, da progressiva quixotização de Sancho e da santificação de Dom Quixote; não se tinha ainda dito claramente como Sancho Pança constituía um 'protótipo para o romance moderno, 122 ainda que certamente grandes escritores como Laurence Sterne (The Life and Opinions of Tristam Shandy) o tivessem percebido e aproveitado na sua obra; não se tinha ainda notado como também com Sancho Pança, e desde a constituição do nome, Cervantes constrói a matricial ambigüidade do seu livro; não tinha ainda Dámaso Alonso (1950) escrito esse belíssimo texto sobre "el largo y complicado

\footnotetext{
${ }^{122}$ Ibidem, p.90. Para essa autora, somente na década de 60 do século XX, haverá uma preocupação nesse sentido através dos estudos de Raymond S. Willis.
} 
proceso de engano y desengaño que nos ofrece nuestro amigo Sancho Panza." (ABREU, 1994, p.90)

Diante da exposição de Abreu, fica pouco a dizer sobre essa crítica de Pinheiro Chagas, já que essa autora ressalta com propriedade uma modernidade em formação apresentada nesse estudo do autor do Poema da Mocidade. Diferentemente daquilo que os historiadores literários divulgam sobre a imagem da crítica de Chagas, sempre por meio de um aspecto negativo e regressivo; pois, para eles, os únicos ideais progressivos e humanísticos presentes no Portugal oitocentista, a partir da Questão coimbrãa, estarão presentes nos discursos da facção literária da qual Pinheiro Chagas não fazia parte.

Retomando, o início da derrocada da personalidade literária do autor de Poema da mocidade começa na Questão coimbrã e prosseguirá durante toda a sua vida pública e literária em que se manteve opositor às concepções dos membros da geração nova, principalmente nas polêmicas travadas com Eça de Queirós. Esse antagonismo de Chagas foi determinante para que fosse estabelecido para ele o papel definitivo de "eterno zoilo da Geração de 70”, assim Ferreira (1966) e Medina (1974) o encarceraram em suas histórias. Dessa maneira, foi nossa proposta retificar essa marginalização tão injustamente imposta a Pinheiro Chagas e a todo seu espólio literário. 


\section{CONSIDERACÕES FINAIS}

Esperamos ter esclarecido que as polêmicas ocorridas no Portugal oitocentista, a partir de 1865, foram decisivas para a marginalização, nas histórias literárias, de alguns escritores que participavam da literatura oficial desse período. Nessa época, as polêmicas constituíam, para os escritores, uma oportunidade de ganhar notoriedade, e assim, poderem formar o público que iria consumir a sua literatura, já que Portugal era um meio literário muito pequeno e restrito.

Foi nossa intenção demonstrar - por meio dos desdobramentos que fizemos na trajetória historiográfica de Pinheiro Chagas como polígrafo e político - as impressões negativas na sua imagem advindas das relações que este manteve com os literatos de seu tempo. O caráter de polemista apaixonado de Chagas ficou tão evidenciado em suas controvérsias que até mesmo naquelas em que entrava para auxiliar um amigo, este assumia a dianteira dos ataques. Prova disso é a Questão Coimbrã que, apesar de ter sido Castilho o causador dessa contenda, fora Pinheiro Chagas o dono do combate. Essa impressão é, em menor número, recuperada por alguns autores, como João Gaspar (s.d), que defendem a idéia de que Castilho - cego e decrépito - era um títere nas mãos de seu pupilo Chagas, responsável por tudo que acontecera na querela de 1865-66.

Para nós, a exclusão de Chagas do cânone português deve-se em boa parte às polêmicas que disputou com Eça de Queirós. Essas controvérsias, sem falar do seu valor incontestável como crítica social e política, serviram para mostrar o grande domínio do seu vencedor, Eça, como observador sagaz, cheio de verve e ironia. Com maestria, este 
desenhou o retrato-sátira de Chagas como escritor com uma sobrecasaca séria de conselheiro de Estado, discursando aos quatro cantos de Portugal sobre a magnitude de uma nação em decadência. Uma ilustre personalidade, sempre contestadora daqueles que ousassem rir da pátria incomparável. Nessas contendas, é evidente o talento eciano, apesar de na maioria dos temas polemizados, ter tido Pinheiro Chagas certa razão em contestá-lo. Entendemos, a partir disso, que o espelhamento caricato feito por Eça passa a ser uma referência bibliográfica, cuja citação não só ilustra os entraves enfrentados pela geração nova nas suas investidas na renovação das letras, como também justifica as causas do apagamento desse escritor, enquadrado num lugar à sombra, quase totalmente olvidado. Curiosamente, o retrato de Chagas, que já faz parte do imaginário coletivo das histórias literárias, é o de ter sido ele uma personalidade ilustre, envaidecido pela sua erudição, sempre rodeado de fama e glória, que não perdia tempo de escarnecer a ignorância histórica dos seus adversários e, muito menos, de se voltar contra os maledicentes que ofendiam a nação.

Em sentido mais profundo, o projeto caricatural de Eça para Pinheiro Chagas o encerra definitivamente fora do rol dos imortais. Para que o leitor possa nos entender, é necessário retornar à primeira resposta de Eça à polêmica Brasil e Portugal. Nessa, seu autor num ímpeto de simulado rancor promete: "Hei de assassiná-lo no quinto ato..." (QUEIRÓS, $N C$, s.d, v.II, p.1405). Pelo que discutimos até aqui, vimos que a promessa de Eça se cumpriu, ele só não ridicularizou a imagem da figura literária de Pinheiro Chagas durante todo o período das polêmicas, mas também contribuiu para o seu apagamento no cânone português.

Talvez, uma das justificativas que encontramos para a ridicularização de Chagas, por meio da charge eciana, esteja na perda de respeitabilidade de seu discurso. Sabemos que o 
autor do Poema da Mocidade participava de todos os campos que poderiam criar essa deferência: como professor acadêmico, jornalista, crítico, escritor e político. Contudo, esse mesmo reconhecimento público na sua época ajudou a reduzir a sua fortuna crítica, anos depois, nas histórias literárias, pois o estudo crítico sobre o século XIX não desassocia a imagem do escritor de sua biografia. Em nossa opinião, as histórias literárias resgatam dos textos polêmicos ecianos definições para representar a participação de Chagas no seu tempo, destacando-lhe: o oportunismo - no sentido que ele atacava a tudo e a todos que lhe fosse conveniente; o viver às custas do trabalho das letras - que lhe favoreceu também o alcance de outras posições burocráticas ${ }^{123}$; e, por último, a posição de um dos líderes da cotérie literária dominante que rivalizou contra a nova literatura que surgia. Dessa maneira, nossas observações podem parecer parciais por estarmos relacionando o ostracismo literário desse escritor inteiramente ao fato de ter representado o tipo de literatura e patriotismo que a geração nova tentou combater, e não por ter sido o seu espólio literário datado para sua época. Por outro lado, não podemos nos esquecer de que uma prática habitual nessas histórias consiste em exaltar um escritor em detrimento de outros tantos.

É uma realidade, a obra multiforme de Chagas praticamente não é estudada, talvez por sua imagem depreciativa já cristalizada, divulgada pela geração de 70 , especialmente por Eça e recuperada pelas histórias literárias. Mas pelo que verificamos em nossa discussão, muitas considerações de Chagas tiveram respaldo de alguns críticos do século XX. Sendo os estudos de Abreu (1994), apresentados por nós, os mais autorizados a destituir a imagem negativa da crítica de Chagas. Nesses, sua autora identifica um certo tipo de modernidade, em um texto de nosso autor sobre Dom Quixote, ao associar de forma

\footnotetext{
${ }^{123}$ Não podemos nos esquecer de que Eça discutiu esse tema excessivamente em As farpas. Na concepção do autor de $O s$ Maias (QUEIRÓS, UCA, s.d, p.1969), "quando um sujeito consegue ter assim escrito três romances, a consciência pública reconhece que ele tem servido à causa do progresso e dá-se-lhe a pasta da fazenda."
} 
inteligente e sensível aspectos que somente foram percebidos e analisados na mesma medida no século XX, a partir dos anos 60, por Antonio José Saraiva.

Possivelmente, depois de uma revisitação às obras de Chagas, descubram-se outros aspectos desse autor que foi indelevelmente refletido, até os nossos dias, pelo monóculo deformador de Eça de Queirós. Para nós, a visão do autor de O Mandarim contamina o olhar de quase toda a crítica que se debruçou até hoje sobre a literatura do seu tempo, persistindo em abandonar o autor do Poema da mocidade no século XIX, como se ele nenhum interesse tivesse para além de ter sido um antagonista dos novos. Tentamos aqui mostrar que isso não é a inteira verdade. 


\section{REFERÊNCIAS BIBLIOGRAFICAS}

ABREU, Maria Fernanda de. O prefácio de Pinheiro Chagas (1876). In: Cervantes no Romantismo português. Cavaleiros andantes, manuscritos encontrados e gargalhadas moralíssimas. Lisboa: Editorial Estampa, 1994. pp.77-92

ALMEIDA, Antonio Ramos. Pinheiro Chagas. In: Simões, João Gaspar. Perspectiva da literatura portuguesa do século XIX. Vol I. Lisboa: Edições Ática, 1947. pp.573-583

AMARAL, Eloy do; MARTHA, M. Cardoso. Eça de Queirós “In Memoriam”, 2a. Ed. Coimbra: Atlântida, 1947. pp.281-287

ARANHA, Brito. Manuel Pinheiro Chagas. In: Dicionário bibliográfico português. Estudos de Inocêncio Francisco da Silva. Tomo XVI. Lisboa: Imprensa Nacional, 1893. pp.288-297

ASSIS, Machado. O primo Basílio. In: Crítica literária. Rio de Janeiro: W.M. Jackson Inc. Editores, [1878]1938. pp.160-86

AZEVEDO, Antonio Carlos do Amaral. Dicionário de nomes, termos e conceitos históricos. Colaboração de Rodrigo Lacerda. 3a . Ed. Rio de Janeiro: Nova Fronteira, 1999. pp. 278 e $419-420$

BASTOS, Sousa. Carteira do artista. Apontamentos para a história do teatro português e brasileiro. Principais artistas, escritores dramáticos e compositores estrangeiros. Lisboa: Antiga Casa Bertrand, 1898. pp 413-414

BELÉM, Cunha. Os contemporâneos. In: ARANHA,Brito. Dicionário bibliográfico português. Estudos de Inocêncio Francisco da Silva. Tomo XVI. Lisboa: Imprensa Nacional, 1893. pp.289

BERRINI, Beatriz. Literatura e arte. Uma antologia. Apresentação, organização geral e comentários. Lisboa: Relógio D’ Água Editores, 2000

BOITO Jr, Armando. A comuna dos trabalhadores. In: Jornal da Unicamp. nº165. Campinas/São Paulo, agosto/2001 . Disponível em: <http://www.unicamp.br/unicamp/unicamp-hoje/ju/ago2001/unihoje-ju165pag18.html.> acessado em: jul.2006.

BOURDIEU, Pierre. O poder simbólico. Trad. Fernando Tomaz. DIFEL. Lisboa, 1998. 
A economia das trocas simbólicas. Introdução, organização e seleção. Sérgio Miceli. Editora Perspectiva, 2004.

BRAGA, Teófilo. As modernas idéias da literatura portuguesa. O Ultra-romantismo vol.VI. Porto: Livraria Internacional de Ernesto Chardron. Casa Editora Lugan \& Genilioux, Sucessores, 1892.

As teocracias literárias. In: FERREIRA, Alberto. Bom senso e bom gosto. Questão coimbrã. Textos integrais da polêmica; recolha, notas e biobibliografia por Maria José Marinho, 4 vols, Lisboa: Portugália Editora, [1865] 1966-1970. pp.193

O Sr. Pinheiro Chagas e o desenvolvimento da literatura portuguesa. In: Os críticos da história da literatura portuguesa. Exame das afirmações dos Srs. Oliveira Martins, Antero de Quental e Pinheiro Chagas. Porto: Imprensa Portuguesa Editora, 1872. pp.41-48

O ultra-romantismo. In: História do teatro português. Garrett e os dramas românticos. Séc. XIX. Porto: Imprensa Portuguesa Editora, 1871 pp.272-290

BRUNO, Sampaio. A geração nova. Ensaios críticos. Os novelistas. Porto: Lello \& Irmão - Editores, 1984.

. Os modernos publicistas portugueses. Cap. II. Porto: Livraria Chardron, 1906.

BUESCU, Helena Carvalhão. Dicionário do romantismo literário português. coord. Lisboa: caminho, 1997. pp 88-89

CABRAL, Alexandre. Acerca de um plebiscito literário em 1884. In: Vértice Revista de Cultura e Arte. Vol 33/34. nºs.353,354-355, Coimbra: Atlântida, junho a agosto de 1973.

CAMPATO, João Adalberto. Retórica e literatura. O Alencar polemista nas cartas sobre A confederação dos Tamoios. São Paulo: Scortecci, 2003.

CARREIRO, José Bruno. Antero de Quental. Subsídios para a sua biografia. Vol I. Lisboa: Edição do Instituto Cultural de Ponta - Delgada, 1948.

CARVALHO, Maria Amália Vaz de Carvalho. Relatório de Pinheiro Chagas In: Crônicas de Valentina. Lisboa: Editores Tavares Cardoso e Irmão, 1890. pp.299-312

. Pinheiro Chagas In: Ao correr do tempo. Lisboa: Parceria Antonio Maria Pereira, 1906. pp. 119-132

CASTILHO, Antonio Feliciano de. Pinheiro Chagas. cap. XXIII In: Telas literárias. Vol IV. Lisboa: Empresa da História de Portugal Sociedade Editora, 1907. pp.11-25 
Crítica literária. In: CHAGAS, Manuel Pinheiro. Poema da mocidade. Seguido do anjo do lar. 2a . Ed. Lisboa: Parceria Antonio Maria Pereira, [1865]1901. pp.159-198

CHAGAS, Manuel Pinheiro. A demolição da coluna de Vendôme; $O$ incêndio de Paris; Consummatum est; Os precursores do comunismo; Comuna e descentralização; Pensamentos ibéricos. In: Vermelhos, brancos e azuis, s.d [1871-1873], p.23-49 e183-190

. In: A ilustração. $5^{\circ}$. Ano Vol V n ${ }^{\circ}$ 13. Lisboa, 1888

08.06.1885, p.3

. Garret e o seu tempo. In: A ilustração portuguesa. $\mathrm{n}^{\circ}$ 50. Lisboa,

- Desenvolvimento da literatura portuguesa. Tese para o concurso da Terceira Cadeira do Curso Superior de Letras. Lisboa: Imprensa de J. G. de Souza Neves, 1872. pp.7-47

. Ensaios críticos. Porto: Em Casa de Viúva Moré Editora, 1866

. História da revolução da comuna de Paris. Vol I e II. Lisboa: Tipografia Lisbonense, [1872] s.d.

. Novos ensaios críticos.Porto: Em Casa da Viúva More Editora, 1867.

Poema da mocidade. Seguido do Anjo do Lar. 2a . Ed. Lisboa: Parceria Antonio Maria Pereira, [1865]1901.

. Prefácio. In.: SAAVEDRA, Miguel de Cervantes. $O$ engenhoso Dom Quixote de la Mancha. Trad. Visconde de Castilho e de Azevedo. Vol. I e II. Porto: Imprensa da Companhia Literária, 1876.

. Anuário do arquivo pitoresco, $\mathrm{n}^{\circ}$ 5. 05/05/1864. Seção de Artes e Letras. In: FERREIRA, Alberto. Bom senso e bom gosto. Questão coimbrã. Textos integrais da polêmica; recolha, notas e biobibliografia por Maria José Marinho, 4 vols, Lisboa: Portugália Editora, 1966-1970. pp.362-366

. Jornal do comércio. Lisboa: 05/05/1865 e 11/08/1865. In: FERREIRA, Alberto. Bom senso e bom gosto. Questão coimbrã. Textos integrais da polêmica; recolha, notas e biobibliografia por Maria José Marinho, 4 vols, Lisboa: Portugália Editora, 19661970. pp. 302-303 e 309-313

. Relatório da Academia. In: AMARAL, Eloy do; MARTHA, M. Cardoso. Eça de Queirós “In Memoriam”, 2a . Ed. Coimbra: Atlântida, [1887]1947. pp.281-287

. Diário de Notícias.(fragmentos) [19.06.1871]. In: MATOS, A. Campos. Org. Dicionário de Eça de Queirós. 2a . Ed. Lisboa: Editorial Caminho, 1988. pp.177 
COELHO, Jacinto do Prado. Dicionário de literatura. Literatura brasileira, literatura portuguesa, literatura galega. Estilística literária. Vol I. A.M. Rio de Janeiro: GB. Companhia Brasileira de Publicações, 1969.

Dicionário enciclopédico luso-brasileiro em dois volumes. Org. e publicado pela Livraria Lello e Irmão. Sob a direção de José Lello e Edgar Lello. Vol I. Porto: Lello Universal, 1974. pp.195 e 983

FERREIRA, Alberto. Bom senso e bom gosto. Questão coimbrã. Textos Integrais da polêmica; recolha, notas e biobibliografia por Maria José Marinho, 4 vols, Lisboa: Portugália Editora, 1966-1970.

LDA, 1971. Perspectiva do romantismo português (1834-1865). Lisboa: Edições 70

FERRÃO, Martens. Diário do Governo de 14.08.1871. In: Polêmica. Eça de Queirós Pinheiro Chagas. "Brasil e Portugal”. Lisboa: Parceria Antonio Maria Pereira, 2001. pp.345

FIGUEIREDO, Cândido de. Homens e Letras. Galeria de Poetas Contemporâneos. Lisboa: Tipografia Universal, 1881. pp.77-81 e 385-387

FIGUEIREDO, Fidelino de. Literatura Portuguesa. Desenvolvimento histórico das origens à atualidade. Rio de Janeiro: Editora A Noite, 1940.

Clássica Editora, 1916.

História da crítica literária em Portugal. 2ª.ed. Lisboa: Livraria

FONSECA, Guimarães. Gazeta de Portugal. In: FERREIRA, Alberto. Bom senso e bom gosto. Questão coimbrã. Textos Integrais da polêmica; recolha, notas e biobibliografia por Maria José Marinho, 4 vols, Lisboa: Portugália Editora, [1865]1966-1970. pp.358-359

FONTANA, Remy J. A comuna de Paris - 130 anos. In: Revista Espaço Acadêmico, no 00. Campinas,2001. disponível em:<//http://www.espacoacademico.com.br/000/0fontana.htm.> acessado em : jul.2006.

FRANÇA, José Augusto. Apresentação e notas. As conferências do cassino no parlamento. Lisboa: Livros Horizonte, Lda, 1973.

. Os anos de contestação (1865-1880). O romantismo em Portugal.

Lisboa: Livros Horizonte, 1992.

Grande enciclopédia portuguesa e brasileira. Vol XXI. Lisboa/Rio de janeiro: Editorial Enciclopédia Ltda., 1945. pp.751-754 
GUIMARÃES, Hélio de Seixas. Romero, Arararipe, Veríssimo e a recepção crítica do romance machadiano. In.: Estudos avançados 18, 2004. pp.269-284

HESS, Rainer. Os inícios da lírica moderna em Portugal (1865-1890) Trad. Maria Antonio Hörster e Renato Correia. Lisboa: Imprensa Nacional, 1978.

HESSEL, Lothan. Alguns autores da segunda geração. In: Boletim do Gabinete Português de Leitura. Gil Vicente, século XIX em Portugal. Porto Alegre. Editora Meridional "EMMA", janeiro, 1966. pp.59-66

JÚDICE, Nuno. Prefácio. In: CHAGAS, Manuel Pinheiro. Julieta. Lisboa: Edições Rolim, 1985.

LEMOS, Esther de. Polêmicas de Eça de Queirós. In: As grandes polêmicas portuguesas. Vol II. Lisboa: Editorial Verbo, s.d. pp.227-242

LINS, Álvaro. História da literatura de Eça de Queirós. Rio de Janeiro: Livraria José Olímpio Editora, 1939.

História literária de Eça de Queirós. São Paulo, 1945. pp.101-104

LISBOA, Eugênio. (coordenação). Dicionário cronológico de autores portugueses. Vol. II. Lisboa: Publicações Europa-América, s.d. pp.239-241

. Org. sel. e introdução. No Eça, nem com uma flor se toca. Eça visto por Régio. Lisboa: Norprint, S.A., s.d.

LOURENÇO, Eduardo. Da literatura como interpretação de Portugal. In: O labirinto da saudade. 2ª Edição.Lisboa: Dom Quixote, 1982. p.85-126

LUIS, Teixeira. Alvorada de agosto. Lisboa: Livraria Clássica Editora,1949. pp.181-187

LUSO, João. Prefácio e recolha. Polêmicas de Eça de Queirós. Rio de Janeiro/Lisboa. Edições Dois Mundos, 1945.

MACHADO, Álvaro Manuel. Dicionário de literatura portuguesa. Lisboa: Editorial Presença, 1996.

O romantismo na poesia portuguesa. De Garrett a Antero. Lisboa: Oficinas Gráficas da Minerva do Comércio de Veiga e Antunes Lda., 1986.

MARTINS, Oliveira. $O$ atentado contra Pinheiro Chagas. In : O repórter. Vol I Lisboa: Guimarães e C ${ }^{a}$. Editores, 1957. pp.181 e 296-297 . Portugal contemporâneo. Vol. II. Porto: Artes Gráficas, [1881]1981. 
MARTOCQ, Bernard. Molière, Castilho e a geração de 70. In: Colóquio Letras $\mathrm{n}^{\mathrm{o}} 28$, novembro de 1975. pp. 39-46

MARX, Karl; ENGELS, Friedrich. Textos. Vol. I. São Paulo: Edições Sociais, 1975. pp.157-206

MATEUS, Osório. Um ofício em centenário. In: Colóquio letras, nº 28, novembro de 1975. pp.35-38

MATOS, A. Campos. Org. Dicionário de Eça de Queirós. 2a . Ed. Lisboa: Editorial Caminho, 1988.

Polêmica. Eça de Queirós - Pinheiro Chagas. "Brasil e Portugal". Lisboa: Parceria Antonio Maria Pereira, 2001.

MATOS, Sérgio Campos. Historiografia e memória nacional no Portugal do século XIX. (1846-1898). Lisboa: Edições Colibri, 1998. pp.37-39

MEDINA, João. Para a história do anarquismo luso: O atentado contra Pinheiro Chagas. In: Eça, Antero e Victor Hugo. Estudos sobre a cultura portuguesa do século XIX. Cap.IV. Lisboa: Centro de História da Universidade de Lisboa, 2001. pp.109-114

. Pinheiro Chagas, A virgem vermelha e a bengala do anarquista. In: Seara nova, $\mathrm{n}^{\mathrm{o}}$ 1539/1540. Propriedade e Editora: Empresa de Publicidade, janeiro/fevereiro de 1974. p.17-21, p.26-30.

MEIRELES, Germano. In: Ferreira, Alberto. Bom senso e bom gosto - Questão coimbrã, textos Integrais da polêmica; recolha, notas e biobliografia por Maria José Marinho, 4 vols, Lisboa: Portugália Editora, 1966-1970. pp.342

MELO, Gladstone Chaves de. Alencar e a língua brasileira. Seguida de Alencar, cultor e artifice da língua. $3^{\text {a }}$. Ed. Rio de Janeiro: Conselho Federal de Cultura, 1972.

MENDES, Margarida Vieira. Questão coimbrã. In: Dicionário do romantismo literário português. Coordenação Helena Carvalhão Buescu, Lisboa: Caminho,1997. p.453-459

MOISÉS, Massaud. A literatura portuguesa. 33ª . Ed. São Paulo: Editora Cultrix, 2005

MONTEIRO, Mário. Pinheiro Chagas. Patriota e amigo do Brasil. Rio de Janeiro: Editora Livraria Francisco Alves, 1943.

MOOG, Viana. Eça de Queirós e o século XIX. Porto Alegre: Edição da Livraria do Globo, 1938. 
NETO, A.L. Machado. Estrutura social da república das letras. Sociologia da vida intelectual brasileira - 1870-1930. São Paulo, Grijalbo, Ed. da Universidade de São Paulo, 1973. pp.125-164

NEVES, Álvaro. Eça de Queirós, acadêmico [1919]. In: AMARAL, Eloy do; MARTHA, M. Cardoso. Eça de Queirós “In Memoriam”, 2a . Ed. Coimbra: Atlântida, 1947. pp.281287

OLIVEIRA, Carla Mary S. O que é ciência e o fazer ciência para Bourdieu? In: PAR'A'IWA. Revista dos pós-graduandos de Sociologia da UFPB. No01. João Pessoa. Dezembro, 2001. Disponível em:<http://www.cchla.ufpb.br/paraiwa/01-oliveira-1.html. acessado em: mar/2007

OLIVEIRA, Paulo Motta. Camilo entre tempos: trajetórias historiográficas. XX Encontro de professores brasileiros de literatura portuguesa. No limite dos sentidos. Niterói. ago.2005. CD-ROM.

ORTIGÃO, Ramalho; QUEIROZ. Eça de. As farpas. sel. e pref. de Gilberto Freire. Vol. I. Rio de Janeiro: Dois Mundos - Editora Ltda, [1871-1872]1943.

ORTIGÃO, Ramalho. Correio de hoje. (1870-1871) Tomo II. Lisboa: Livraria Clássica Editora A. M. Teixeira e Ca (Filhos), 1948.

PALMA-FERREIRA, João. Literatura portuguesa. História e crítica. Lisboa: Imprensa Nacional- Casa da Moeda, 1985.

PINA, Mariano. In: A ilustração. 5. Ano Vol V nº 10. Lisboa, 1888.

1945. . In: Eça de Queirós. O homem e o artista. Lisboa: Edição dos Mundos,

QUEIROS, Alberto. A conferência do Sr. Eça de Queirós. In:BERRINI, Beatriz. Literatura e arte. Uma antologia. Apresentação, organização geral e comentários. Lisboa: Relógio D' Água Editores, [1871] 2000. pp.22-26

QUEIROS, Eça. Obras Completas. Vol. II e III. Porto: Lello \& Irmão Editores, s.d.

- Literatura e arte. Uma antologia. Apresentação, organização geral e comentários Beatriz Berrini. Lisboa: Relógio D’ Água Editores, 2000.

QUENTAL, Antero de. Cartas de Antero de Quental. 3 ${ }^{\text {a }}$ Ed. Coimbra: Imprensa de Universidade, 1921. pp.83-84

. A dignidade das letras e as literaturas oficiais. In: FERREIRA, Alberto. Bom senso e bom gosto. Questão coimbrã. Textos Integrais da polêmica; recolha, notas e biobibliografia por Maria José Marinho, 4 vols, Lisboa: Portugália Editora, [1865]19661970. pp. 225 
. Considerações sobre a filosofia da história literária portuguesa. In:

Prosas. Vol II. Lisboa: Couto Martins, s.d., pp.208-240

. Prosas. Vol II. Lisboa: Couto Martins, s.d.

. In: CARREIRO, José Bruno. Antero de Quental. Subsídios para a sua biografia. Vol I. Lisboa: Edição do Instituto Cultural de Ponta - Delgada, 1948.pp.291

RAMOS, Feliciano. Eça de Queirós e os seus últimos valores. Lisboa: Edição da Revista, 1945. pp.117-41

REBELLO, Luiz Francisco. 120 anos de literatura teatral portuguesa, Lisboa: Círculo do Livro, 1968.

RÉGIO, José. Problemas de crítica literária I [1942]. O sonho de a relíquia ou Pinheiro Chagas tinha razão [1945]. Eça de Queirós Pinheiro Chagas e o caso português [1945]. Os Heróis do Eça [1955]. In: Lisboa, Eugênio. Org. sel. e introdução. No Eça, nem com uma flor se toca. Eça visto por Régio. Lisboa: Norprint, S.A., s.d.

REIS, Carlos; PIRES, Maria da Natividade. História crítica da literatura portuguesa. O romantismo. Vol. 5. Coimbra: Editorial Verbo, 1993.

REIS, Carlos. Literatura portuguesa moderna e contemporânea. Lisboa: Universidade Aberta, 1990.

Alfa, 2001.

. Direção. História da literatura portuguesa. Vol. I, Lisboa: Publicações

RODRIGUES, Ernesto. O ultra-romantismo. In: Dicionário do romantismo literário português. Coord. Helena Carvalhão Buescu. Caminho: Lisboa, 1997. pp.563-66

SALGADO JR, Antonio. História das conferências. In: Dicionário de Eça de Queiroz. Org. e coord. de A. Campos Matos. 2a . Ed. revista e aumentada. Lisboa: Editorial Caminho, [1871] 1988. pp.172-179

SAMPAIO, Albino Forjaz de. História da literatura portuguesa ilustrada dos séculos XIX e XX. Porto: Livraria Fernando Machado, s.d.

SANTOS, Antonio Ribeiro dos. A pedagogia social em Antero e em Castilho. In: Colóquio letras, 1991. pp.37-51

SARAIVA, Antonio José; Lopes, Oscar. História da literatura portuguesa. 17 ed. Porto: Editora Ltda., 1996. 
SARAIVA, Antonio José. História da literatura portuguesa I. Das origens ao romantismo. Lisboa: Editorial Estúdio Cor, s.d.

SARAIVA, José Hermano. História concisa de Portugal. 5a Ed., s.local: Coleção saber Publicações Europa-América, 1979. pp.315-339

SAYERS, Raymond S. Machado de Assis no Portugal do século XIX; Relações entre a literatura brasileira e a portuguesa no século XIX; A literatura brasileira no Portugal oitocentista: Os críticos, os jornais, as revistas. In: Onze estudos de literatura brasileira. Tradução de Roberto Raposo. Rio de Janeiro: Civilização Brasileira; [Brasília]: INL, 1983. pp.123-141 e 191-232

SÉRGIO, Antonio. Breve interpretação da história de Portugal. Lisboa: Livraria Sá da Costa Editora, 1978.

SERRÃO, Joel. A geração de 70 e o público. Sondagem cultural à sociedade portuguesa de cerca de 1870. In. O tempo e o Modo. s.d, p.119

. Antero de Quental. Prosas sociopolíticas. Lisboa, Imp. Nacional-Casa da Moeda, 1982. p.30 e 31-32

1992. pp.16-20 e 508-519

.Dicionário de História de Portugal. Vol. V. Porto: Livraria Figueirinhas,

SIMÕES, João Gaspar. A geração de 70. Alguns tópicos para a sua história. Lisboa: Editorial Inquérito Ltda., s.d.

. História do romance Português. Vol. II. Lisboa: Estúdios Cor, 1969.

1945.

. Eça de Queirós. O homem e o artista. Lisboa: Edição dos Mundos, . Vida e obra de Eça de Queirós. 3ª Ed. Lisboa: Livraria Bertrand, 1980.

SOUTO, José Correia de. Dicionário da literatura portuguesa. Vol. IV. Porto: Lello e Irmão, s.d.

SOUZA, João de Cruz e. In: NETO, A.L. Machado. Estrutura social da república das letras. Sociologia da vida intelectual brasileira - 1870-1930. São Paulo, Grijalbo, Ed. da Universidade de São Paulo, 1973. pp.142

STERNE, Irwin. Eça de Queirós versus Pinheiro Chagas. In: Colóquio Letras nº55, maio de 1980.

TEIXEIRA, Luis. Alvorada de Agosto. Lisboa: Livraria Clássica Editora, 1949. pp.181-187

VALDEMAR, Antonio. O Peso da Memória. Lisboa: Edições Inapa, 1989. pp.45-63 
VAN TIEGHEN, Philippe. História ilustrada das grandes literaturas. Trad. Pref. notas de Jacinto do Prado Coelho. Vol II. Lisboa: Editorial Estudios Cor, 1955, pp. 344-345

VENÂNCIO, Fernando. Estilo e preconceito. A língua literária em Portugal no tempo de Castilho. Lisboa: Edições Cosmos, 1998.

VENTURA, Roberto. Estilo tropical: História cultural e polêmicas literárias no Brasil, 1870-1914. São Paulo: Companhia das Letras, 1991. 